\title{
Enhancing SME innovation performance
}

Citation for published version (APA):

Mennens, K. M. A. G. (2019). Enhancing SME innovation performance: results from a multi-actor perspective. [Doctoral Thesis, Maastricht University]. Off Page Amsterdam. https://doi.org/10.26481/dis.20190228km

Document status and date:

Published: 01/01/2019

DOI:

10.26481/dis.20190228km

Document Version:

Publisher's PDF, also known as Version of record

\section{Please check the document version of this publication:}

- A submitted manuscript is the version of the article upon submission and before peer-review. There can be important differences between the submitted version and the official published version of record.

People interested in the research are advised to contact the author for the final version of the publication, or visit the DOI to the publisher's website.

- The final author version and the galley proof are versions of the publication after peer review.

- The final published version features the final layout of the paper including the volume, issue and page numbers.

Link to publication

\footnotetext{
General rights rights.

- You may freely distribute the URL identifying the publication in the public portal. please follow below link for the End User Agreement:

www.umlib.nl/taverne-license

Take down policy

If you believe that this document breaches copyright please contact us at:

repository@maastrichtuniversity.nl

providing details and we will investigate your claim.
}

Copyright and moral rights for the publications made accessible in the public portal are retained by the authors and/or other copyright owners and it is a condition of accessing publications that users recognise and abide by the legal requirements associated with these

- Users may download and print one copy of any publication from the public portal for the purpose of private study or research.

- You may not further distribute the material or use it for any profit-making activity or commercial gain

If the publication is distributed under the terms of Article $25 \mathrm{fa}$ of the Dutch Copyright Act, indicated by the "Taverne" license above, 


\title{
Enhancing SME innovation performance
}

Results from a multi-actor perspective

\author{
Kars Mennens
}

Maastricht University 
(C) Kars Mennens, Maastricht 2019

All rights reserved. No part of this publication may be reprinted or utilized in any form or by any electronic, mechanical or other means, now known, or hereafter invented, including photocopying and recording, or in any information storage or retrieval system, without permission from the copyright owner.

Cover design by Aleksandr Zyrianov

ISBN: 978-94-6182-941-2

Layout and printing Off Page, Amsterdam, The Netherlands 


\title{
Enhancing SME innovation performance
} Results from a multi-actor perspective

\author{
DISSERTATION
}

to obtain the degree of Doctor at Maastricht University, on the authority of the Rector Magnificus, Prof. dr. Rianne Letschert, in accordance with the decision of the Board of Deans, to be defended in public on Thursday February 28 2019, at 14.00 hours.

by

Kars Martijn Anne Gerard Mennens 


\section{Supervisor}

Prof. Dr. Gaby Odekerken-Schröder

\section{Co-supervisors}

Prof. Dr. Wilko Letterie

Dr. Anita Van Gils

\section{Assessment Committee}

Prof. Dr. Elisabeth Brüggen, Chair

Prof. Dr. Andries de Grip

Prof. Dr. Ir. Bart Nieuwenhuis (Universiteit Twente en Fontys Venlo)

Dr. Myriam Cloodt (Technische Universiteit Eindhoven)

\section{Sponsor}

Province of Limburg 


\title{
Preface
}

\author{
"Manufacturing SMEs represent the cork that allows the economy of \\ this province to float." \\ — Twan Beurskens, former Deputy Economic Affairs, Province of Limburg
}

Provinces pay close attention to the economic value created by the small and mediumsized enterprises (SMEs) within their borders, rather than focusing solely on large organizations. Embracing this philosophy, Limburg decided to initiate the LimburgMakers subsidy program in 2013, offering various instruments to SMEs, including knowledge vouchers and innovation project subsidies. The goal was to increase the innovativeness of Limburg's manufacturing industry structurally, because innovative performance can increase economic competitiveness, address societal challenges, and support the transformation of societies (European Commission, 2013). Therefore, policy makers seek to help businesses by fostering a dynamic business environment that facilitates entrepreneurship and innovation, thereby enabling the SMEs to reach their full potential (OECD, 2018).

In Limburg, the manufacturing industry is vital, accounting for $16 \%$ of all employment opportunities, a strong export component, and an enabler of other industries such as healthcare, logistics, and agriculture/food. The LimburgMakers program aims to stimulate knowledge exchanges and learning across these manufacturing sectors and universities, because, according to Twan Beurskens, "the time in which universities were just an ivory tower has passed. Today, knowledge institutions disseminate their knowledge to the outside world. Governments and businesses can use their own experience to further develop this knowledge, utilize it and generate revenue from it. Furthermore, collaboration with university scholars can complement an entrepreneur's lack of time to conduct research and development."

To evaluate the economic value of the LimburgMakers subsidy program, the province acted on Beurskens's push by initiating a triple helix research collaboration among a knowledge institution (UM School of Business and Economics), a development and investment company (LIOF), and the local government (Province of Limburg). This dissertation summarizes the fruits of this collaboration, in three empirical studies. With these research projects, my co-authors and I examine the SME innovation process from the perspectives of three important actors: policy makers, SMEs, and customers. With this multi-actor perspective, we formulate a holistic answer to the question: How can the innovation performance of manufacturing SMEs be enhanced? 


\section{Acknowledgements}

On September 15, 2015, my very first meeting as a PhD candidate at development and investment company LIOF started off with a bold question: "Nice to meet you, Kars. I'm very curious: How long are you going to last?" Having seen other PhD-students come and go, the gentlemen were skeptical about the research project. I smiled and replied: "I am going to finish it." There was not a doubt in my mind. Not only because I am positive by nature or get excited when a challenge presents itself - but also because I knew that if times would really get tough, I have great friends, family and colleagues who would support me. For that I thank all of you.

I wholeheartedly thank my three supervisors for guiding me throughout my $\mathrm{PhD}$. Members of different departments, brought together by a common goal: Helping me get my doctorate. To me, the mix of your strengths has resulted in an incredibly powerful learning environment and allowed me to take the fast lane during my PhD: Gaby, the energy you beam on the people around you is truly inspiring. Because of your everlasting positivity and ability to spot opportunities, I always left our meetings with more ideas than I brought to the table. You taught me so many things, and I hope I can continue to learn from you in the future. I appreciate that, despite your stuffed agenda, you always took the time to discuss personal matters as well. Wilko, I admire your pragmatism and critical thinking. Whether it was a theory or an analysis, if it got past your judgment I knew I was in the clear. Next to this, your extremely sharp eye for detail and ability to pick out a needle in a haystack will never seize to amaze me: I think you could compete with Word's grammar control at finding one double blank in a complete dissertation. Anita, you have been my trump card. I know the past years have not always been easy for you, and I deeply respect your strength. If a smoke alarm would have gone off at SBE, I am sure I would have called you first; you walk through fire for your students. Thanks for putting so much effort in reviewing and improving my work.

Next, I would like to express my gratitude to Jan Maatjens, Charles Mevis and Ruud Nissen for their collaboration and dedication to this research project. Your experience and enthusiasm have been very valuable, and key to making my research relevant for SMEs, LIOF and the Province of Limburg.

I would like to thank Lisa Brüggen, for chairing the reading committee for this dissertation. Having fulfilled an integral role in the LimburgMakers program by connecting SMEs to SBE students, I cannot imagine anyone more suited to take on the job. Also, I would like to express my appreciation to the members of the reading committee: Andries de Grip, Bart Nieuwenhuis and Myriam Cloodt, thank you for the time and effort you invested in assessing the quality of my work.

I also owe my gratitude to all colleagues from the Marketing \& Supply Chain Management and Organization \& Strategy departments for helping me during my PhD, and for having made the SBE such a nice place to work. It feels like an honor to have worked with so many bright and talented minds. Emma and Baer, thank you for kick 
starting this research project. Jasper and Matthias, I am grateful you were there at the start. Ile, Lek, Marleen, Hannah, Stefi and Tim - my man cave buddy, thanks for making F2.02 an office where work and fun could go hand in hand. Kimberley, Martina and Susan, your daily smalltalk has been a welcome disturbance in between all the intellectual discussions. Mark, I wish our collaboration had taken longer. Your crazy brainfarts made my day, I hope you are going to drive everyone at SBE nuts when you return. Adela, Anita and Nicole, I appreciate all your assistance, support and care. Pascalle and Eefje, I want to thank you for not only that, but for so much more. For making sure that a good laugh or a serious conversation were just a few steps away. For ascertaining I did not walk around SBE with a deep hairline in my neck. For putting me in my place every now and then. For being my friends.

Bij het behalen van mijn PhD hebben mijn familie en vrienden minstens net zo'n belangrijke rol gespeeld als mijn collega's binnen de poort van de SBE: Jullie hebben mij zowel geestelijk als lichamelijk gezond gehouden. Ik verkeer in de enorme luxepositie te kunnen zeggen dat jullie met te veel zijn om allemaal hier te benoemen, maar ik hoop dat iedereen die er voor mij geweest is en momenten van vreugde, vriendschap en liefde met mij gedeeld heeft weet dat ik je voor altijd dankbaar ben.

Guy, Thijs, Bart en Rick, ik waardeer de epische daden die we samen hebben verricht op de Malpertuisstraat 25: Ik denk dat niemand ooit zal kunnen tippen aan onze Schrobbelèr collectie, en dat Van Basten en Van Nistelrooy nergens zoveel gescoord hebben als in ons Ultimate Team. Met jullie leek het alsof het iedere doordeweekse avond weekend was. Guy, jij bent de enige vriend met wie ik af en toe constructief in de clinch kan liggen. Dat is bijzonder, en alleszeggend. Terence, ik ben ontzettend blij dat ik een vriend heb die zo oprecht, eigenzinnig en geeky is als jij. Hoe leeg zou mijn leven zijn zonder Smallworld, Caverna of Rick \& Morty?! Sem, ik hecht veel waarde aan onze vriendschap, en ik hoop dat ik nog lang van je persoonlijkheid en ongeëvenaarde kwaliteit mensen op te kunnen hitsen mag genieten. Sven en Erwin, ik heb gesmuld van onze tochten op de racefiets. De duizend doden die ik ben gestorven in het zadel maakten het eenvoudig om PhDgerelateerde zaken te relativeren. Daan, groei alsjeblieft nooit op; ik koester je Peter Pan complex. Coen, het is bijzonder om een vriend vanaf de peuterschool aan je zijde te hebben. Bedankt voor de organisatie van zo'n beetje alle activiteiten met de boys. Luc, Jelle, Jasper, Roy, Levin, Jur, Niels \& Marc, ook jullie bedankt voor de buikpijn van het lachen tijdens onze steden- en voetbaltrips.

Een misschien wat ongebruikelijker dankwoord gaat uit naar de Steenakker - thuisbasis van RKDFC en de plek waar ik altijd mijn hoofd leeg kon maken vanaf het moment dat ik het veld opstapte. Bedankt voor alle feestjes, katers, historische wedstrijden en kleedkamerhumor.

Pap en mam, jullie hebben mij iets gegeven dat veel te makkelijk als vanzelfsprekend wordt gezien: Een thuisbasis, een plek waar ik altijd welkom ben en waar liefde, bescherming en steun onvoorwaardelijk zijn. Bedankt dat jullie er altijd voor me zijn. 
Ik had mij geen betere ouders kunnen wensen. Je hebt je familie nu eenmaal niet voor het uitkiezen, dus Jord en Bouke, ik besef me hoeveel geluk ik ook heb met twee zo'n fantastische broertjes. Bouke, het is geweldig om jou op te zien groeien. Bedankt voor alle ellendige middagen die je me bespaard hebt door de bal in het netje te prikken op zondag. Jord, het feit dat jij als een van mijn paranimfen naast me staat benadrukt onze speciale band. Ik hoop dat we voor altijd samen kunnen blijven feesten. Over familie gesproken: Ruud - mijn broeder van een andere moeder - ik ben je ontzettend dankbaar voor je gezelschap tijdens de late kantooruren. Ik heb ervan genoten. Als anderen net zoveel energie en enthousiasme zouden steken in het ontwikkelen van een nieuw "groen beleid" als wij, zouden klimaatproblemen allang geen issue meer zijn. Jan, Beppie, Paul, Bibiana en Saartje, bedankt voor alles. Ik heb me vanaf de eerste dag thuis gevoeld bij jullie en prijs mezelf ontzettend gelukkig dat ik deel uitmaak van de Stipjes familie.

Ik ben nog niet klaar, want ik heb het beste tot het laatst bewaard. Mijn grootste fan, mijn belangrijkste ambassadeur, mijn onbetaalbare organisator, en de liefde van mijn leven. Lieve Lisa, bedankt voor al je geduld, je steun en je onvoorwaardelijke liefde. Je was niet alleen mijn metgezel tijdens het maken van deze reis, jij bent de eindbestemming. Ik draag dit proefschrift op aan jou.

Kars Mennens, Maastricht, December 2018 


\section{Table of contents}

Preface $\quad 5$

Acknowledgements 6

List of figures 10

List of tables 11

$\begin{array}{lll}\text { Chapter } 1 & \text { Introduction } & 13\end{array}$

Chapter 2 Behavioural additionality: The impact of innovation subsidies on 25 employee involvement in SMEs

Chapter 3 Exploring antecedents of service innovation performance in manufacturing SMEs

Chapter 4 Identifying customer requirements for

SMEs' servitized offerings - A dyadic study

$\begin{array}{lll}\text { Chapter } 5 & \text { Conclusion } & 93\end{array}$

$\begin{array}{ll}\text { References } & 103\end{array}$

$\begin{array}{ll}\text { Appendix: Interview guide } & 121\end{array}$

$\begin{array}{ll}\text { Valorization addendum } & 127\end{array}$

Summary 133

$\begin{array}{ll}\text { Curriculum vitae } & 137\end{array}$ 


\section{List of figures}

Chapter 1 Figure 1.1. Dissertation research model 22

Chapter 2 Figure 2.1. Dissertation research model - Focus of chapter 26

Chapter 3 Figure 3.1. Dissertation research model - Focus of chapter $3 \quad 46$

Figure 3.2. Structural model 54

$\begin{array}{ll}\text { Figure 3.3. Results } & 61\end{array}$

Chapter 4 Figure 4.1. Dissertation research model - Focus of chapter 4

Chapter 5 Figure 5.1. Research model depicting different actors in 97 SME innovation process 


\section{List of tables}

Chapter 1 Table 1.1. Overview of the studies 19

Chapter 2 Table 2.1. Empirical investigations of behavioural additionality 32

Table 2.2. Probit estimation of the probability of treatment 39

Table 2.3. Descriptive statistics of covariates before and after matching 39

Table 2.4. Treatment effect on Employee Involvement 40

Table 2.5. Additional regression analysis 41

Chapter 3 Table 3.1. Measurement Scales 56

Table 3.2. Reliability, Validity and Measurement Model 59

Table 3.3. Correlations and Square Roots of 60 the Average Variance Extracted (on the Diagonal)

Chapter 4 Table 4.1. Overview of SMEs and customers participating in the study 77

Table 4.2. SME co-creation with customers when anticipating customer 78 requirements for servitized offerings and underlying motivations

Table 4.3. Taxonomy of customer requirements for servitized offerings per servitization strategy 



\section{Chapter 1}

Introduction 



\section{Innovation in SMEs: A multi-actor perspective}

In this dissertation, I put innovation by manufacturing small and medium-sized enterprises (SMEs) under a microscope. This focus is highly relevant; just as in other parts of the world, manufacturing SMEs are the beating heart of the economy in the province of Limburg (LIOF, 2013). For example, 99 of every 100 companies in the European Union (EU) are SMEs, such that they provide employment to two-thirds of the labour force and account for 57 cents of every euro of value added (European Commission, 2018). Manufacturing is one of the five main industries in which SMEs are active (European Commission, 2018). In this role, SMEs are agents of change that can stimulate the growth and development of an industry (De Jong and Vermeulen, 2006; Herrera and SánchezGonzález, 2013). In addition, SMEs' innovation can counteract low productivity growth and the widening wage and income gaps (OECD, 2018), while also spurring employment (Radas and Božić, 2009).

However, SMEs often fail to realize successful innovation outcomes (Brunswicker and Vanhaverbeke, 2015), usually due to the resource limitations they face (Bessant, 1999; Vossen 1998; Van de Vrande et al., 2009), which prevent SMEs from engaging in all the activities required to realize an innovation (Brunswicker and Vanhaverbeke, 2015). If they do devote sufficient resources to an innovation project, they risk overstraining their capacities (Acs and Audretsch, 1988; Nooteboom, 1994; Rosenbusch et al., 2011; Vossen, 1998). In particular, SMEs struggle to attract and secure financial resources, so access to financing emerges as the most commonly cited barrier to their innovation (Freel, 2000). Moreover, larger organizations have resource slack to absorb missteps, but a failed innovation can represent an existential risk for SMEs (Nohria and Gulati, 1996; Rosenbusch et al., 2011). Insufficient human resources are another common obstacle (Madrid-Guijarro et al., 2009).

According to a systems of innovation approach, "innovation is an interactive process that requires intensive communication and collaboration between different actors, both within companies as well as between firms or other organizations" (Tödtling and Trippl, 2005, p. 1205). Inspired by this approach, I adopt a multi-actor perspective and present a series of empirical studies. In every chapter, I investigate how SME innovation practices might be improved, according to a different perspective. With this approach, I seek a holistic answer to the overarching research question of this dissertation:

What are the drivers of SME innovation performance ${ }^{1}$ ?

Because SME innovation is a key factor of a region's sustainable and competitive development (Beck et al., 2016; Radas and Božić, 2009), with positive impacts on

\footnotetext{
${ }^{1}$ In this dissertation, I define innovation performance as the SME's ability to achieve an innovationbased competitive advantage.
} 
regional economies (OECD, 2018), (local) government policy makers seek to help SMEs overcome their inadequate resources, which inhibit their innovation (Freel, 2000), by establishing public subsidy programs (Clarysse et al., 2009). Therefore, policy makers constitute the first critical group of actors, with important influences on enhancing SMEs' innovation performance. In Chapter 2, I adopt a policy maker perspective and investigate whether innovation policies have an enduring positive effect on the innovation process of SMEs.

Innovation also allows the focal SMEs to grow (Brunswicker and Vanhaverbeke, 2015; European Commission, 2018) and achieve better performance, including higher sales (Hoffman et al., 1998) and increased chances of long-term survival (He and Wong, 2004; Lubatkin et al., 2006). Innovation is a precondition of competitiveness (MadridGuijarro et al., 2009). Considering this clear incentive for SMEs to engage in innovation, I identify manufacturing SMEs themselves as another important actor and take an intra-organizational perspective to discover how manufacturing SMEs work to achieve innovation performance in Chapter 3.

Finally, Sawhney, Wolcott, and Arroniz (2006, p. 77) argue that "customers decide the worth of an innovation by voting with their wallets." Organizations innovate to develop new offerings that create superior customer value, because doing so is vital to the firm's long-term performance (La Rocca et al., 2016). Innovations are introduced to satisfy customer needs (Lusch et al., 2007); manufacturing SMEs are no exception, and they introduce service innovations to align their offerings with customer needs (Baines et al., 2009). The ultimate value of any innovation is determined by the customer, so I pinpoint customers of manufacturing SMES as the third important group of actors in the SME innovation process. In Chapter 4, I embrace a dyadic perspective, representing both SMEs and customers, and analyse the requirements that customers establish for innovative offerings.

\section{Research questions}

Public policy can help mitigate SMEs' financial barriers to innovation (Norrman and BagerSjögren, 2010), and accordingly, the number of innovation support programs in the EU has increased over time (European Commission, 2013). In Limburg for example, a recent study underlined the importance of public support policies to stimulate SME innovation (WijLimburg, 2018), including the LimburgMakers subsidy program, which is the research context for this dissertation. The program was implemented to support manufacturing SMEs in their product innovation efforts and to strengthen the knowledge economy (Cox, 2013).

The impact of innovation subsidies traditionally has been assessed by evaluating their effects on the firm's own R\&D input or innovation output (González and Pazo, 2008; Georghiou, 2002). However, rather than these effects, a subsidy's effect on firm behaviours might exert the strongest impact on the organization (Davenport et al., 1998). 
Policy makers increasingly recognize the potential magnitude of this behavioural effect (Clarysse et al., 2009), but unfortunately, few studies investigate it and instead focus predominantly on collaborations with external partners. Within the organization, it is not sufficient for someone in a position of authority to initiate innovations individually or make strategic decisions to innovate alone (van de Ven, 1986). Instead, firms must provide employees with opportunities to develop problem-solving skills and allow them to make use of their knowledge to succeed with their innovation efforts (OECD, 2018). Receiving an innovation subsidy can provide SMEs with the financial resources to allow their employees to invest more time in innovation (George, 2005). Confirming a positive influence of innovation subsidies on employee involvement would provide policy makers with a new rationale for subsidy programs, because employee involvement has positive effects on organizational change, performance, and employee satisfaction (Caves and Porter, 1977; Denison, 1984; Mendes, 2012; Porter, 1979; Pun and Chin, 1999; Sun et al., 2000; Welikala and Sohal, 2008; Wilkinson, 1998). Following this line of reasoning, I dedicate Chapter 2 to testing for a relationship between receiving an innovation subsidy and employee involvement. By answering the following research question, I seek to enhance policy makers' knowledge of the relevance of subsidy programs:

RQ1: What impact does receiving an innovation subsidy have on SMEs' employee involvement? ${ }^{2}$

The LimburgMakers program sought to support the development of innovative products, yet manufacturing SMEs increasingly realize that offering excellent products is not sufficient (Kowalkowski et al., 2013). Intensifying competition, reflected in price pressure and decreasing product margins, forces organizations to adjust their strategies (Gebauer, Fleisch and Friedli, 2005), such that many formerly product-centric manufacturing SMEs now adopt servitization strategies to achieve competitive advantages (Valtakosi and Witell, 2018). According to a recent industry report, 75\% of manufacturers expect that services will account for a significantly larger share of their business in the next three to five years (PA Consulting Group, 2018). Thus, SMEs have shifted from selling products to selling solutions that integrate products and services (Baines et al., 2009), and this trend is notable in Limburg. In 2013, the province was identified as one of the few regions in the EU with advanced policy thinking in terms of developing its manufacturing industry through service innovation (European Service Innovation Centre, 2013). However, many businesses fail to innovate their services systematically (Gebauer et al., 2008), possibly because they lack a formal approach toward their service innovation efforts (Baines et al., 2009; Storey et al., 2016). In addition, SMEs may not possess the required resources

\footnotetext{
${ }^{2}$ In this dissertation, we use the terms employee collaboration (Ordanini and Parasuraman, 2011) and employee involvement interchangeably.
} 
or experience to develop and provide new services (Kowalkowski et al., 2013). Studies that detail how SMEs might excel in their service innovation efforts - a position that I conceptualize as achieving a competitive advantage based on service innovation - are essential for servitization success, yet they are relatively scarce (Kowalkowski et al., 2013; Van de Vrande et al., 2009). Therefore, I take an intra-organizational SME perspective in Chapter 3 to provide SMEs with insight into how they can arrange their internal organization to support successful service innovation. Specifically, the central question in Chapter 3 is:

RQ2: Which organizational mechanisms allow SMEs to achieve service innovation performance?

Beyond contributing to a competitive advantage (Gebauer, Fleisch and Friedli, 2005), servitization strategies reflect customers' increasing demand for services (Baines et al., 2017; Baines et al., 2009). Many firms fail in their servitization efforts because their offerings do not match what customers want and need (Ambroise et al., 2018; Valtakosi, 2017). Correctly responding to customer needs is especially important for SMEs, so that they can overcome the size, resource, and efficiency disadvantages they suffer, relative to larger firms, such as market power and economies of scale (Alpkan, Yilmaz and Kaya, 2007). In particular, finding customers for products and services is one of SMEs' greatest challenges (European Commission, 2018). Leveraging knowledge about their customers' needs for servitized offerings potentially would help them overcome their size disadvantage and create greater customer value. Co-creation - defined as the process of creating offerings in active collaboration with the customer (Oertzen et al., 2018) directly integrates customers into the innovation process (Green et al., 2017) and thus helps ensure alignment between the servitized offering and customer requirements (Fliess and Lexutt, 2017; Gebauer et al., 2005; Lusch and Vargo, 2006). The most successful servitizers are companies that proactively reach out to customers (PA Consulting Group, 2018). Unfortunately, SMEs may not possess the resources and capabilities to analyse customer requirements adequately (Hsieh and Chou, 2018); that is, SMEs may not always co-create with customers in this process. The extent to which SMEs actually engage in co-creation to anticipate customers' requirements is unknown. Therefore, in Chapter 4, I investigate the first part of my third research question:

RQ3A: To what extent do SMEs engage in co-creation when anticipating customer needs?

In addition, customer perspectives have been overlooked in prior investigations of the servitization of manufacturing and the shift from products to servitized offerings (Raja, Johnson and Goffin, 2015; Valtakosi, 2017). Existing research has been conducted from the perspective of the servitizing, manufacturing firm (e.g. Sjödin et al., 2016), leaving unclear the question of how customers actually evaluate servitized offerings (Evanschitzky, Wangenheim and Woisetschläger, 2011; Hakanen and Jaakkola, 2012). 
In Chapter 4, I aim to fill this gap by taking a dyadic SME-customer perspective that provides SMEs with new insights into customer requirements for servitized offerings. Specifically, I answer the second part of my third research question:

RQ3B: What requirements for servitized offerings do customers have?

\section{Dissertation overview}

The objective of this dissertation is to provide a holistic view of the drivers of SME innovation performance. To this end, I took the perspective of multiple important stakeholders, while using a diverse set of methods of analysis and gathering both quantitative and qualitative data. Table 1.1 provides an overview of the research objectives and theoretical lenses of each empirical Chapter, as well as the data sets and methodology employed and the submission status of each empirical Chapter. In the following, I provide a brief introduction to each of these Chapters.

Table 1.1. Overview of the studies

\begin{tabular}{|c|c|c|c|}
\hline & Chapter 2 & Chapter 3 & Chapter 4 \\
\hline Purpose & $\begin{array}{l}\text { Investigating long-term } \\
\text { effects of receiving } \\
\text { a subsidy on } \\
\text { employee involvement }\end{array}$ & $\begin{array}{l}\text { Identifying antecedents } \\
\text { of service innovation } \\
\text { performance in } \\
\text { manufacturing SMEs }\end{array}$ & $\begin{array}{l}\text { Obtaining in-depth } \\
\text { insights into customer } \\
\text { requirements for } \\
\text { servitized offerings and } \\
\text { how SMEs anticipate } \\
\text { these requirements }\end{array}$ \\
\hline Theoretical lens & $\begin{array}{l}\text { Behavioural additionality } \\
\text { (Clarysse et al., 2009) }\end{array}$ & $\begin{array}{l}\text { Dynamic capabilities } \\
\text { (Teece et al., 1997), } \\
\text { absorptive capacity } \\
\text { (Cohen and } \\
\text { Levinthal, 1990) }\end{array}$ & $\begin{array}{l}\text { Service-dominant logic } \\
\text { (Vargo and Lusch, 2004), } \\
\text { co-creation (Oertzen et } \\
\text { al., 2018) }\end{array}$ \\
\hline Data & $\begin{array}{l}\text { Longitudinal survey } \\
\text { data from SME owner/ } \\
\text { managers }(n=92)\end{array}$ & $\begin{array}{l}\text { Cross-sectional survey } \\
\text { data from servitizing SME } \\
\text { owner/managers }(n=100)\end{array}$ & $\begin{array}{l}\text { Semi-structured interview } \\
\text { data from } 24 \text { dyads } \\
\text { involving } 9 \text { SME owner/ } \\
\text { managers and } 24 \\
\text { customers }\end{array}$ \\
\hline Perspective & Policy maker & Intra-organizational SME & SME-customer dyad \\
\hline Method & $\begin{array}{l}\text { Combined matching and } \\
\text { difference-in-differences } \\
\text { approach }\end{array}$ & $\begin{array}{l}\text { Structural } \\
\text { equation modelling }\end{array}$ & $\begin{array}{l}\text { Qualitative } \\
\text { content analysis }\end{array}$ \\
\hline $\begin{array}{l}\text { Manuscript } \\
\text { submission status }\end{array}$ & $\begin{array}{l}\text { Under review at Small } \\
\text { Business Economics }\end{array}$ & $\begin{array}{l}\text { Published in International } \\
\text { Small Business Journal }\end{array}$ & $\begin{array}{l}\text { Being prepared for } \\
\text { submission to Industrial } \\
\text { Marketing Management }\end{array}$ \\
\hline
\end{tabular}


Chapter 2. A lack of skilled employees is a key challenge to SMEs' innovation (European Commission, 2018), and limited public funding has been devoted specifically to supporting the development of innovation skills (European Commission, 2013). A recent report by the OECD (2018) indicates that when employees have opportunities to develop problem-solving skills and make use of their knowledge, their employing firms are more likely to succeed in their innovation efforts. If firms possess more financial resources, managers typically provide employees with more opportunities to engage in knowledge sharing and learning activities and encourage their employees to participate in strategic activities, including innovation (Chen and Huang, 2010; Ruiz-Moreno et al., 2008; Singh, 1986). Receiving an innovation subsidy thus could alter organizational behaviour related to employee involvement, but to date, this effect has not been investigated. Behavioural additionality research, pertaining to the changes in firm behaviour that occur after receiving public support (Clarysse et al., 2009), predominantly focuses on changes in collaborations with external partners.

In Chapter 2, I therefore investigate whether subsidies that provide support for innovation projects result in increased employee involvement by comparing subsidized relative to unsubsidized SMEs. The test of this behavioural additionality effect relies on a longitudinal data set, involving manufacturing SMEs in the Dutch province of Limburg. The data analysis employs a conditional difference-in-differences method - a combination of nearest neighbour propensity score matching with a difference-in-differences approach (Imbens and Wooldridge, 2009; Karhunen and Huovari, 2015) - and reveals a significantly greater increase in employee involvement among SMEs that receive an innovation subsidy. My findings provide compelling evidence for the impact of innovation subsidies on the internal organization and particularly how employee involvement can be stimulated in SMEs. I also provide a methodological contribution, by capturing the temporal dynamics of behavioural additionality. This study provides policy makers with evidence that subsidy programs affect not just R\&D input or innovation output but also the internal organization, in terms of employee involvement.

Chapter 3. Even though 75\% of manufacturers expect that services will become a more significant part of their business in the next three to five years (PA Consulting Group, 2018), servitization is not a straightforward path for manufacturing organizations (Kindström and Kowalkowski, 2014). Many businesses fail to innovate services systematically (Gebauer et al., 2008) or lack consistent strategies, capabilities, and operating models to support service provision (PA Consulting Group, 2018). Instead, service innovation often is a haphazard process that simply "happens" (Lightfoot and Gebauer, 2011). To attain a competitive advantage based on service innovation, SMEs must figure out how to achieve outstanding service innovation performance.

In Chapter 3, I provide a possible answer. Starting from a dynamic capabilities perspective, I predict that absorptive capacity - or the ability to recognize and assimilate valuable external knowledge and then apply it to commercial ends (Cohen and Levinthal, 1990) - is a critical factor. Absorptive capacity may be driven by employee collaboration 
(i.e., degree to which employees participate in the service innovation process) and the firm's search breadth (i.e., diversity of external innovation partners). With a survey study of Dutch manufacturing SMEs, employing structural equation modelling analysis, I confirm that employee collaboration and search breadth have positive effects on organizations' potential absorptive capacity; employee collaboration also reinforces their realized absorptive capacity. Realized absorptive capacity enables SMEs to exploit external knowledge, ultimately enhancing service innovation performance. Exploiting such external knowledge produces competitive advantages, including those achieved with service innovations (Lusch et al., 2007). These results establish strong theoretical underpinnings for how service innovation can be facilitated within SMEs and offer explicit guidelines to SMEs related to how they can achieve a service-based competitive advantage. I also advance theory on the development of dynamic capabilities in an SME context (Kevill et al., 2017) and contribute to the debate about how openness in the service innovation process might translate into higher market performance (Mina et al., 2014).

Chapter 4. Servitized offerings fundamentally change a manufacturing SME's customer relationships. The most successful servitizing companies proactively reach out to their customers (PA Consulting Group, 2018). The prevalence of servitization strategies reflects customers' demands (Baines et al., 2009), so taking a customer-centric approach is vitally important, especially considering that customers ultimately determine the value of a service (Clegg et al., 2017). Customer co-creation in innovation allows servitizing SMEs to anticipate customer requirements (Fliess and Lexutt, 2017; Oertzen et al., 2018). In this realm, I note two important research gaps: First, SMEs often lack the resources to anticipate customers' requirements (Hsieh and Chou, 2018), and there is no evidence regarding the extent to which SMEs actually engage in co-creation when determining their customer's requirements. Second, even when it advocates a customercentric focus, prior research has overlooked customer perspectives on servitized offerings (Valtakosi, 2017).

In Chapter 4, I address these two research gaps with a dyadic qualitative study and thereby help servitizing SMEs provide more appealing offerings to their customers and enhance their ability to satisfy their customers' needs. With in-depth interviews with 24 SME-customer dyads, I determine that the extent to which they engage in co-creation in the process of defining the requirements for servitized offerings differs across SMEs. Furthermore, customers prioritize different requirements depending on the servitization strategy being pursued by the providing SME. In addition to identifying 9 customer requirements for servitized offerings, and thereby improving understanding of how SMEs should servitize successfully, I demonstrate that SMEs fail to engage in co-creation with their customers. These results offer important implications for practitioners, including guidance for how SMEs should position and devise servitized offerings and nudge customers, so that their attitudes toward the SMEs induce co-creation routines that ultimately improve the alignment between servitized offerings and customer requirements. 


\section{Dissertation outline}

This dissertation presents three distinct empirical studies that together provide a holistic view of the drivers of SME innovation performance. Figure 1.1 presents the overarching research model. In Chapter 2, my co-authors and I adopt a policy maker perspective and investigate how innovation subsidies can contribute to innovation performance. In Chapter 3, I take an intra-organizational perspective and examine the antecedents of service innovation performance in manufacturing SMEs. In Chapter 4, I embrace a dyadic customer-SME view and scrutinize customer requirements for servitized offerings, as well as how SMEs include customers when anticipating these requirements. Finally, in Chapter 5, I summarize the findings and provide a general conclusion to the dissertation, by discussing the theoretical and managerial implications and offering suggestions for future research.

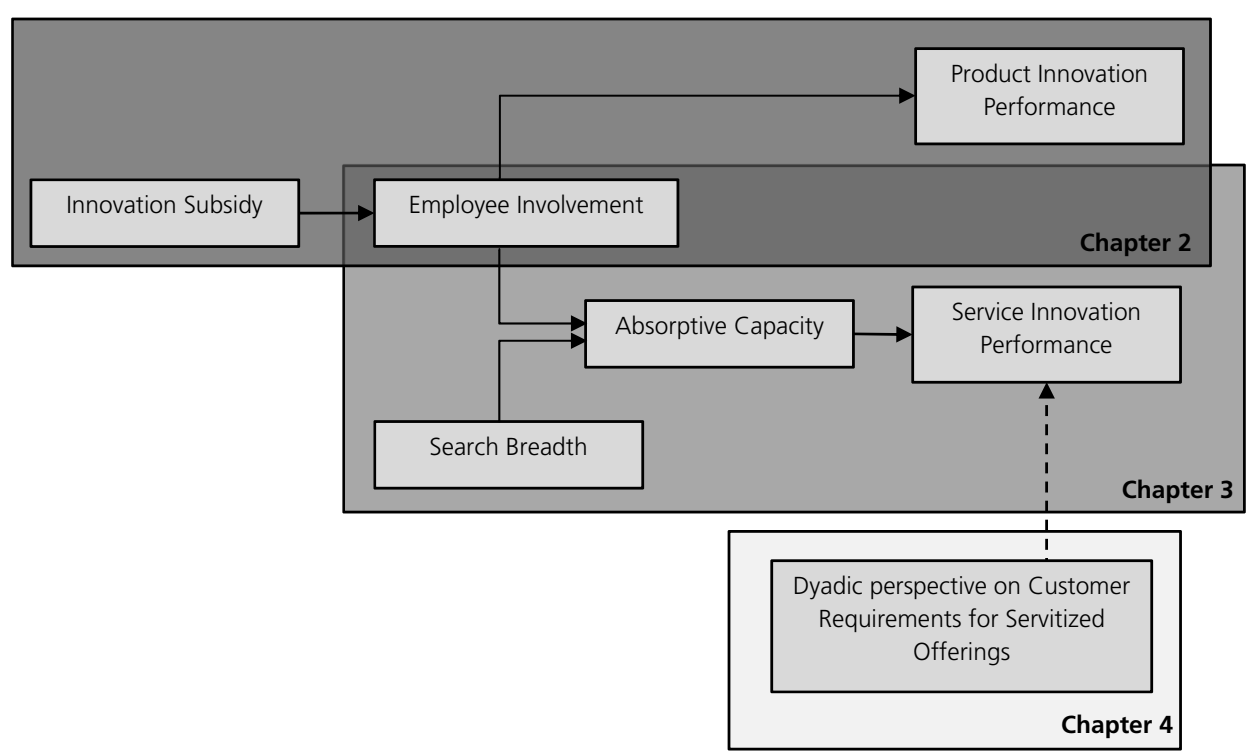

Figure 1.1. Dissertation research model 




\section{Chapter 2}

\section{Behavioural additionality: The impact of innovation subsidies on employee involvement in SMEs}


Chapter 2

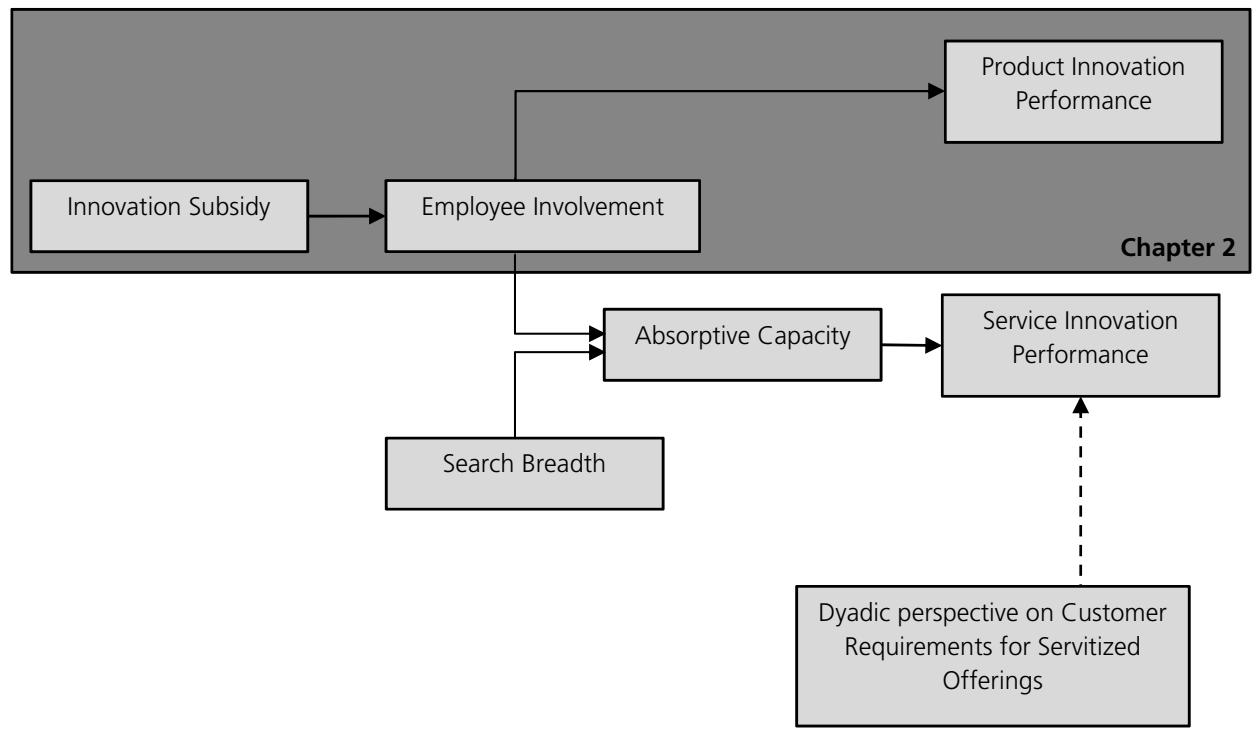

Figure 2.1. Dissertation research model - Focus of chapter 2 


\section{Introduction}

SME innovation is considered as a key driver of a region's sustainable and competitive development (Beck et al., 2016; Radas and Božić, 2009), but a lack of resources often inhibits innovation in SMEs (Freel, 2000). Therefore, policy makers increasingly seek to support SME innovation with innovation subsidy programs (Clarysse et al., 2009). Both researchers and policy makers increasingly seek empirical evidence about whether this type of public money is well spent (Clarysse et al., 2009). In this chapter, we adopt a policy maker perspective on enhancing SME innovation performance by investigating how innovation subsidies can drive changes in organizational behaviour.

Traditionally, three types of research projects investigate this issue, focused on input, output or behavioural additionality. Input additionality studies examine whether innovation subsidies boost private R\&D or act as a substitute for it (González and Pazo, 2008). Typically, receiving an innovation subsidy increases investments in R\&D (Beck et al., 2016). These subsidies also appear more effective for small to medium-sized enterprises (SMEs) than for larger businesses (González and Pazo, 2008). However, this stream of studies does not examine direct links with innovation output, so they cannot reveal whether input additionality always translates into innovative output and economic welfare (Clarysse et al., 2009). Output additionality studies instead examine R\&D outputs such as patents or revenues derived from a new product or service, which would not have been achieved without the subsidy (Georghiou, 2002). Researchers typically report that innovation subsidies have a positive impact on innovation performance (Arvanitis et al., 2010; Czarnitzki and Licht, 2006; Czarnitzki and Lopes-Bento, 2014). Although analysing output additionality is attractive for policy makers, outcomes remain difficult to measure; many other factors, such as inter- and intra-firm spill-overs, also determine the success of a new product or service (Clarysse et al., 2009). Finally, studies of behavioural additionality aim to identify changes in an organization's short- and long-term behaviour as a result of receiving an innovation subsidy (Buisseret et al., 1995; Chávez, 2011). Such investigations are less common than the other two perspectives (Cerulli et al., 2016), and the evidence is largely anecdotal (Clarysse et al., 2009; Falk, 2007), mainly due to the limited availability of useful data. Intangible behavioural changes resulting from an innovation subsidy are hard to measure (Falk, 2007).

Because behavioural additionality effects potentially exert the most durable impact on organizations though (Davenport et al., 1998), some studies examine it empirically. The majority of them focus on collaboration behaviour (Cunningham and Gök, 2012) and reveal that innovation subsidies stimulate external collaboration (e.g., Caloffi et al., 2015; Chávez, 2011), measured as a change in the resources available for collaboration (input) or the number of firms with which the organization collaborates (output). Gök and Edler (2012) assert that a true understanding of behavioural additionality also requires consideration of its internal dynamics. For example, innovation subsidies can lead to upgraded internal competencies or induce changes in senior managers' innovation- 
oriented attitudes (Antonioli et al., 2014; Chapman and Hewitt-Dundas, 2018). However, detailed knowledge about which internal competencies or processes improve is lacking. Therefore, to advance understanding of behavioural additionality, we seek to analyse whether receiving a subsidy can also result in changes in internal collaboration practices (Gök, 2010; Gök and Edler, 2012). That is, we aim to extend knowledge on this perspective by examining the effect of innovation subsidies on employee involvement, a form of behavioural additionality, in the innovation process within SMEs. Thereby, we provide an answer to the first research question of this dissertation:

What impact does receiving an innovation subsidy have on SMEs' employee involvement?

We define employee involvement as the extent to which employees take part in the strategic decision-making process (Amah and Ahiauzu, 2013; Pun et al., 2001). Research emphasises the important role of this type of behaviour in large organizations. Management philosophies such as total quality management and lean management rely on high employee involvement to positively affect organizational change, performance and employee satisfaction (Caves and Porter, 1977; Denison, 1984; Mendes, 2012; Porter, 1979; Pun and Chin, 1999; Sun et al., 2000; Welikala and Sohal, 2008; Wilkinson, 1998). Research on employee involvement in SMEs is limited, though Andries and Czarnitzki (2014) identify its positive effect on innovation performance. We posit that employee involvement may be even more critical to the success of SMEs, relative to large organizations, because smaller firms must fully exploit their workforce resources and rely on their staff to perform learning, innovation and creativity tasks (Castrogiovanni, 2011; Rohlfer, 2008). Innovation subsidies can provide them with the necessary slack in resources, allowing employees to participate in strategic activities such as innovation projects (George, 2005; Ruiz-Moreno et al., 2008).

The findings that we obtain from longitudinal data obtained from the LimburgMakers subsidy program for SMEs indicate that innovation subsidies have a positive influence on employee involvement in strategic decision making. In this unique study, we are first to apply a robust, econometric evaluation method (conditional difference-in-differences) to investigate additionality effects on a specific type of internal organizational behaviour in SMEs. In turn, this study makes several contributions to theory. First, we advance behavioural additionality research. Previous studies focus predominantly on changes in external collaboration behaviour after receiving a subsidy. By investigating employee involvement we shed light on the internal collaboration effects of behavioural additionality. Second, we advance knowledge of what drives employee involvement in SMEs. The prevalence of informal employee relations and lack of unions in these firms means that findings derived from large organizations cannot merely be extended to SMEs (Rohfler, 2008; Sameer and Özbilgin, 2014). Rather, we specify that access to innovation subsidies can provide SMEs with the necessary slack to stimulate more employee involvement in strategic decision- 
making processes. Third, with our longitudinal SME sample, we apply a conditional difference-in-differences method, which also constitutes a methodological contribution. That is, we respond to calls by Autio et al. (2008) for longitudinal studies, preferably using repeated measures from the same projects, to determine the temporal dynamics of behavioural additionality. Our unique data set captures these dynamics.

In the next section, we review existing literature and develop our research questions. After we describe the subsidy program that we analyse, including the sample and measures, we detail our methodology and results. We then discuss the findings and implications of our research. Finally, we suggest some directions for further research.

\section{Literature Review}

In most European countries, public programs seek to support innovation by private firms, and increased interest centres on how to measure the returns to these public innovation investments (Georghiou and Roessner, 2000). We present various approaches to measure these returns in more detail, which helps explain our focus on employee involvement as a form of behavioural additionality.

\section{Input and Output Additionality}

Input additionality deals with the question of whether innovation subsidies boost or replace $R \& D$ investments by the receiving companies (Clarysse et al., 2009; Georghiou, 2002). It is the most traditional and widely used concept to evaluate the effectiveness of innovation subsidies; it relates closely to the crowding-out/crowding-in debate (Clarysse et al., 2009). In input additionality terms, an instrument is effective if every Euro of government support leads to at least one Euro of private, organizational funds invested (Georghiou, 2002). Yet public funds also might create inefficiencies (e.g. higher salaries for researchers) or substitute for R\&D that would have taken place without the subsidy (Clarysse et al., 2009). If public support substitutes for private investments, managers and public policy makers need to understand why; otherwise, their designs of public funding programs might be self-defeating. If they are complements though, these actors need to understand the leveraging effect so that they can take optimal advantage of it (Brooks, 2000). In addition, substantial empirical evidence already suggests a positive effect of public subsidies on short-term input additionality measures. For example, Aerts and Schmidt (2008) find that funded firms are significantly more active in R\&D than are non-funded firms. Czarnitzki and Licht (2006) offer similar findings when they address input additionality as R\&D and innovation expenditures. However, an important concern associated with using input additionality to evaluate innovation subsidies is that no direct link is possible between innovation input and output. It is questionable whether input additionality translates into innovative output and economic welfare (Clarysse et al., 2009). 
Output additionality offers another method to evaluate the effect of subsidy programs. Georghiou (2002) defines it as the proportion of outputs from the R\&D process which would not have been achieved without public support. Whereas input additionality deals with the degree to which public efforts activate additional R\&D efforts by the private firm, output additionality focuses on how much additional innovation output a subsidy has created. This metric can be measured by direct firm-level innovations (patents, papers, prototypes) or as indirect firm-level innovation outputs, such as new products or the application of new processes and services (Clarysse et al., 2009). More general firm performance indicators (turnover, profit, productivity) also might reveal output effects of R\&D support (Clarysse et al., 2009). In output additionality terms, empirical evidence again confirms a positive effect of public support on innovation performance. For example, Czarnitzki and Hussinger (2004) and Czarnitzki and Licht (2006) identify substantial additionality in public R\&D grants pertaining to innovation outputs (i.e. patent outcomes and applications). Hewitt-Dundas and Roper (2010) suggest that innovation subsidies encourage firms to initiate new projects and improve the quality and sophistication of their innovation activities. However, due to within- and betweenfirm spill-overs, it is difficult to specify a one-on-one relationship between an innovation subsidy and its output (Clarysse et al., 2009). In settings marked by substantial spill-overs, non-supported firms reap the benefits of a public subsidy, which leads to underestimates of the effect of the program in comparisons of supported versus non-supported firms (Klette et al., 2000).

In summary, input and output additionality deal with whether private R\&D investment or innovation outputs are boosted by public R\&D support for private research. They do not necessarily shed light on how public subsidies lead to additionality. Georghiou and Roessner (2000) accordingly call for complementary methods that capture the noneconomic benefits of subsidies more comprehensively. In a similar vein, Falk (2007) notes that traditional additionality conceptualizations do not adequately capture the impact of public subsidies on the innovation process. In response, researchers have started to investigate behavioural additionality effects of innovation subsidies.

\section{Behavioural Additionality}

The notion of behavioural additionality, introduced by Buisseret et al. (1995), pertains to firm behaviour that results from public support. It represents a complement to input and output additionality. According to Falk (2007), few studies of behavioural additionality use an econometric approach, likely because of the difficulty of measuring such behaviour.

As the overview of empirical research in Table 2.1 indicates, with only 12 studies, evidence of behavioural additionality remains limited. Furthermore, only Chapman and Hewitt-Dundas (2018) address an SME-specific context. Rather, most existing research focuses on external cooperation behaviour or the network dimension to assess organizational change and behavioural additionality (e.g. Busom and Fernandez-Ribas, 
2008; Cerulli et al., 2016; Clarysse et al., 2006; Falk, 2007). These studies measure collaboration behaviour as changes in the resources available for collaboration or in the number of firms with which the organization collaborates. They reveal that publicly funded firms engage more actively in collaboration with other firms and public research organizations, both during and after the project term (Georghiou and Clarysse, 2006). In a similar vein, Fier et al. (2006) uncover significant changes in the patterns of technological collaboration; they report that new business and science collaborations remain durable, and innovation subsidies stimulate firms' search for new partners. Only 4 of the 12 studies in Table 2.1 report on internal behavioural additionality effects. Specifically, Hsu et al. (2009) claim that innovation subsidies cause changes in a firm's strategy. Chapman and Hewitt-Dundas (2018) argue that subsidies can induce small positive changes in managerial attitudes toward innovation. Subsidies also might stimulate organizational learning, thereby improving organizational competencies and behaviour (Antonioli et al., 2014; Autio et al., 2008). However, we lack detailed knowledge about precisely which forms of internal behaviour change after a subsidy has been received (Gök, 2010).

\section{Employee Involvement and Slack Resources}

One important type of internal organizational behaviour is employee involvement, which we consider as one of the facets of behavioural additionality. Employee involvement is the extent to which employees take part in the strategic decision-making process (Amah and Ahiauzu, 2013; Pun et al., 2001). It drives organizational change and performance (Mendes, 2012; Sun et al., 2000; Welikala and Sohal, 2008; Wilkinson, 1998). For example, including employees in the decision-making process as members of strategic groups prompts enduring changes in firm profitability and organizational effectiveness (Caves and Porter, 1977; Porter, 1979). Denison (1984) finds that perceived employee involvement predicts current and future financial performance, and involved employees also report higher satisfaction levels and quality of life at work (Pun and Chin, 1999; Zatzick and Iverson, 2011). Similar effects emerge from SME settings, where employee involvement becomes even more important (Castrogiovanni, 2011; Rohlfer, 2018), prompting innovation performance (Andries and Czarnitzki, 2014) and exhibiting a positive association with process innovation in particular (Uhlaner et al., 2013). Uhlaner et al. (2013) caution that there is also a cost to employee involvement though, in that it may have a negative impact on an SME's sales growth if employees redirect their activities. However, these costs can be offset as long as employee involvement adds value to the development of new ideas (Uhlaner et al., 2013).

Receiving an innovation subsidy increases the level of an SME's slack resources, and these potentially usable resources can be diverted or redeployed to achieve organizational goals. Slack resources can facilitate strategic behaviour, enabling organizations to develop new strategies (Ruiz-Moreno et al., 2008). In particular, an innovation subsidy increases an SME's financial slack, by creating funds that can be redirected toward innovation 
Table 2.1. Empirical investigations of behavioural additionality

\begin{tabular}{|c|c|c|c|}
\hline Authors (year) & Sample & $\begin{array}{l}\text { Longitudinal } \\
\text { analysis }\end{array}$ & $\begin{array}{l}\text { Explicit focus on internal } \\
\text { behavioural additionality effects? }\end{array}$ \\
\hline $\begin{array}{l}\text { Antonioli, Marzucchi \& } \\
\text { Montresor (2014) }\end{array}$ & $\begin{array}{l}408 \text { Italian } \\
\text { manufacturing firms }\end{array}$ & & $x$ \\
\hline $\begin{array}{l}\text { Autio, Kanninen \& } \\
\text { Gustafsson (2008) }\end{array}$ & 66 Finnish firms & & $x$ \\
\hline $\begin{array}{l}\text { Busom \& } \\
\text { Fernández-Ribas (2008) }\end{array}$ & $\begin{array}{l}716 \text { Spanish } \\
\text { manufacturing firms }\end{array}$ & & \\
\hline $\begin{array}{l}\text { Cerulli, Gabriele \& } \\
\text { Potì (2016) }\end{array}$ & 1106 Italian firms & $\begin{array}{l}X \\
1998-2000 \text { and } \\
2002-2004\end{array}$ & \\
\hline $\begin{array}{l}\text { Chapman \& } \\
\text { Hewitt-Dundas (2018) }\end{array}$ & $\begin{array}{l}620 \text { United } \\
\text { Kingdom SMEs }\end{array}$ & & $x$ \\
\hline Chávez (2011) & $\begin{array}{l}\text { 3249* Spanish } \\
\text { manufacturing firms }\end{array}$ & & \\
\hline $\begin{array}{l}\text { Clarysse, Wright \& } \\
\text { Mustar (2009) }\end{array}$ & 276 Belgian firms & & \\
\hline Falk (2007) & 1298 Austrian firms & & \\
\hline $\begin{array}{l}\text { Hsu, Horng \& } \\
\text { Hsueh (2009) }\end{array}$ & 216 Taiwanese firms & & $x$ \\
\hline $\begin{array}{l}\text { Neicu, Teirlinck \& } \\
\text { Kelchtermans (2016) }\end{array}$ & 127 Belgian firms & & \\
\hline $\begin{array}{l}\text { Rossi, Caloffi \& } \\
\text { Russo (2016) }\end{array}$ & 819 Italian firms & $\begin{array}{l}x \\
2002-2008\end{array}$ & \\
\hline $\begin{array}{l}\text { Wanzenböck, Scherngell \& } \\
\text { Fischer (2013) }\end{array}$ & 155 Austrian firms & & \\
\hline
\end{tabular}

*Multiple samples are used in this study, and 3249 is the average sample size. 


\section{Findings}

Innovation subsidies can make firms more active as learning organizations, allowing them to be more efficient in terms of extending and/or upgrading competencies. Innovation cooperation with other business partners remains unaffected in most cases.

A shared community identity among participants of collaborative innovation programs is positively associated with organizational learning (boost of technological learning and distinctiveness, market learning and internationalization learning).

Participation in an R\&D program increases the probability that organizations cooperate with a public research organization and, to a lesser extent, the probability of partnerships with customers and suppliers.

Participation in innovation policy programs has a strong, positive effect on cooperation. Cooperation above a certain threshold value can reinforce the relationship between input additionality and product innovation propensity.

Innovation vouchers induce small positive changes in senior managers' innovation-oriented attitudes.

Regional subsidies foster cooperation with universities and technological centres for organizations not engaged in innovation collaboration; national subsidies stimulate cooperation with universities and technological centres for organizations already engaged in innovation collaboration.

Learning as a result of receiving an innovation subsidy leads to increased behavioural additionality. The learning effects decrease with the number of subsidized projects undertaken by the company.

Additionalities start to accrue already during the application process. Different forms of innovation subsidies are necessary to ensure behavioural additionality effects such as more cooperation.

Behavioural additionality can be classified as project enlargement, strategy formulation, cost effectiveness and commercialization behaviour.

Innovation subsidies induce tax credit users to focus more on research relative to development and to accelerate the execution of R\&D projects. Firms scale up their current R\&D and initiate additional projects.

The imposition of policy requirements is unlikely to induce persistent changes in organizations' networking behaviour.

R\&D-intensive firms are less likely to substantiate behavioural additionalities; small, young and technologically specialized firms are more likely to realize behavioural additionalities. 
projects with uncertain outcomes (George, 2005). When firms possess slack resources, managers recognize and encourage innovation. They realize that valuing and creating perceptions of support for innovation must translate into practices for employees, such as participating in decision making (Ruiz-Moreno et al., 2008); it is not sufficient for someone in a position of authority to initiate innovation individually or make a strategic decision to innovate alone (van de Ven, 1986). Slack resources also are associated with risk taking and proactive strategic choices, which can encourage convergence between personal and organizational goals (George, 2005). In turn, slack provides employees with space, time and support to engage actively in knowledge sharing and learning activities (Chen and Huang, 2010), which may lead to more decentralized decision making (Singh, 1986). Therefore, we predict that receiving an innovation subsidy increases employee involvement in SMEs.

\section{Background, Data and Methodology}

\section{LimburgMakers Subsidy Program}

This study investigates the LimburgMakers program, which commenced in September 2013 and ended in December 2016. Its main objective was to stimulate innovation and enhance the competitiveness and sustainability of manufacturing SMEs in the Dutch province of Limburg. The manufacturing industry provides $16 \%$ of all employment opportunities in this province. It also features a strong export component (27\%), relative to the average in the Netherlands (18\%), and demands high knowledge intensity. Furthermore, it functions as an important enabler of other important industries in the province, such as healthcare and agro/food.

The LimburgMakers program featured six subsidy instruments, including knowledge vouchers, knowledge trajectories at a university and subsidies for innovation projects. Eligible SMEs had to have developed and realized innovative physical components, end products or services (e.g. software) that added value to a product. A committee of policy makers and SME owners assessed 403 applications and granted 193 subsidies, for a total amount of $€ 7,200,000$. Most subsidies ( $N=95$ ) related to innovation projects, for a total of $€ 6,300,000$, which meant these SMEs obtained financial support to develop an innovative product or service that could structurally enhance their competitiveness. The maximum amount provided per firm was $€ 70,000$, and it could not cover more than $35 \%$ of the total project costs. Typically, innovation subsidies support less than $50 \%$ of an innovation project (Czarnitzki and Licht, 2006). Then the second most common subsidy instrument was a knowledge voucher, and the 45 granted subsidies of this type accounted for $€ 280,000$. Because both the number of granted subsidies and the total amount of public money spent on them are the greatest, by far, for the innovation project, we solely focus on analysing the effects of this type of subsidy in this study. 


\section{Data and Measurements}

In early 2014, right after the launch of the LimburgMakers subsidy program, we identified all 1711 SMEs in the manufacturing industry in the province of Limburg, then sent a questionnaire to their owners or managers, asking about the firms' organizational behaviour and innovation-related variables. No subsidies had been granted th that time. Based on the definition by the European Union, we define an SME as an organization that employs up to 250 people. The SMEs received an email with a link to the online survey. If we received no response, we sent a reminder email. Thereafter, we sent a reminder letter by postal mail, including a printed survey and reply envelope. A total of 246 SMEs responded, for a response rate of $14.4 \%$-normal for this type of research (Baum et al., 2001; Mennens et al., 2018; Moreno and Casillas, 2008; Wiklund and Shepherd, 2005). In February 2016, we sent a second questionnaire out to all the organizations that answered the first survey, along with reminder emails and two telephone contacts if they did not respond. In an ultimate attempt to obtain maximum responses, we made in-person visits to some companies to administer the survey. We thus obtained 92 longitudinal responses (response rate $=37.4 \%$ ), of which 40 had received an innovation subsidy and 52 had not.

To measure our dependent variable, employee involvement, we use the 7-point Likert perceptual scale from Ordanini and Parasuraman (2011), with the items "Employees are actively engaged in establishing goals and priorities for our strategies" and "Employees are adequately represented on project teams and other strategic activities." We measure the involvement of all employees, because involving not only managerial, but also nonmanagerial employees has a significant impact on innovation performance (Andries \& Czarnitzki, 2014). The treatment variable (innovation subsidies) is a dummy, equal to 1 if the SME received a LimburgMakers innovation project subsidy and 0 if not. Busso et al. (2014) recommend including control variables if they are expected to influence both the treatment selection process and the outcome variable, to prevent estimation bias. Accordingly, we include firm age (age and age squared, similar to Karhunen and Huovari, 2015), because older firms may be more reluctant to innovate (Balasubramanian and Lee, 2008; Chapman and Hewitt-Dundas, 2018), such that they might apply less often for innovation subsidies, and their employees might be less inclined to be involved in innovation processes. We also control for firm size, measured as the logarithm of the number of employees (Huergo and Jaumandreu, 2004); we take the logarithm to avoid biases due to skewness of the data (Aerts and Schmidt, 2008). Then, similar to Hottenrott and Lopes-Bento (2014), we control for each SME's diversity of innovation partners. The SMEs that collaborate with a wider variety of external partners may be more aware of external funding opportunities, such as innovation subsidies. Furthermore, their employees could be more involved in strategic decision making, such as when frontline service employees cooperate with external partners regularly and thus can provide managers with important knowledge insights. We control for growth ambition for the next five years, because SMEs with greater such ambitions likely invest 
more effort in their innovation process (Schumpeter, 1942). In this sense, we expect that growth ambition spurs both the search for innovation subsidy possibilities and employee involvement. Previous product and process innovation activity also represent control variables in our analysis, because preceding SME innovation activity influences subsequent innovative behaviour (Cassiman and Golovko, 2011). Finally, we included an SME's frontline employee education, which we defined as an employee that is in direct contact with the market, noting that the expertise of those employees can influence an SME's ability to attract public funding. Moreover, we assume that the level of frontline employee education can be seen as a proxy for the general level of employee education. Employees with more education are more intrinsically motivated (Kaiser, 2006), which energizes and gives direction to their behaviour (Islam and Ismail, 2008) and thus should enhance employee involvement. We asked respondents to indicate the extent to which they agreed that "Front-line employees are highly educated."

\section{Method}

Storey (2000) suggests assessing the effect of an SME policy by monitoring techniques as well as evaluation methods. Monitoring relies on the opinions and views of recipients of the subsidy; evaluation methods attempt to contrast these opinions according to the outcomes achieved from receiving versus not receiving a subsidy. However, R\&D subsidies are not randomly distributed (Klette et al., 2000; Meuleman and De Maeseneire, 2012) but rather are assigned through a selection process (Herrera and Nieto, 2008), which produces a risk of sample selection bias (Herrera and Nieto, 2008). A frequently used method to overcome this issue is propensity score matching (Cerulli, 2010, Herrera and Nieto, 2008). Accordingly, we calculate a subsidy assignment probability-based probit, which reflects the firm's propensity to receive a subsidy, given a set of observable, pre-treatment characteristics $P(X)$. These characteristics should affect both the treatment and the outcome (Rosenbaum and Rubin, 1983). With this propensity score, we can estimate the average treatment effect on the treated (ATT) of an SME policy. The ATT in turn indicates the impact of innovation subsidies. Evaluation requires a comparison of the outcome of the dependent variable when receiving a subsidy ( $Y^{s}$, referred to as the factual state) against its value in the absence of a subsidy $\left(Y^{c}\right.$, or counterfactual state). The ATT can be defined as:

$$
\mathrm{ATT}=E\left(Y^{S}-Y^{C} \mid P(X), T=1\right)=\frac{1}{N_{S}} \sum_{i=1}^{N_{S}}\left(Y_{i}^{S}-\sum_{j=1}^{N_{C}} W(i, j) Y_{j}^{C}\right)
$$

where $Y_{j}^{s}$ denotes employee involvement in SME $i$ which receives a subsidy, and $Y_{j}^{c}$ denotes employee involvement in SME $j$ which does not receive a subsidy. In addition, $W(i, j)$ the weight function that determines how the unsubsidized SME $j$ is weighted relative to the subsidized SME $i$. Furthermore, Ns and Nc indicate the number of observed firms in 
the treatment and control groups, respectively. The main advantage of using a propensity score, rather than other methods such as selection models, is that no functional form for the outcome equation is required, nor is a distributional assumption about the error terms of the selection and outcome equation (Caliendo and Kopeinig, 2008; Czarnitzki and Lopes-Bento, 2014).

Our longitudinal SME data enable us to use the conditional difference-in-differences (CDID) method and thereby further reduce possible biases by differencing the outcome variable, employee involvement, before and after the treatment. This evaluation approach is robust when combined with a matching estimator (Imbens and Wooldridge, 2009; Karhunen and Huovari, 2015). A combined approach requires inserting different time periods into Equation 1. We therefore define $t$ and $t^{\prime}$ as the time periods after and before the innovation subsidies are granted:

$$
\mathrm{ATT}=\frac{1}{N_{S}} \sum_{i=1}^{N_{S}}\left[Y_{i t}^{S}-Y_{i t}^{S}-\sum_{j=1}^{N_{C}} W(i, j)\left(Y_{j t}^{C}-Y_{j t \prime}^{C}\right)\right]
$$

Proper use of this method requires two assumptions: conditional independence and common support. The conditional independence assumption demands that counterfactual outcomes are independent of the treatment indicator, conditional on the covariates. That is, given a set of covariates $X$, the outcomes of the control group are the same as the outcomes of the treated group, had they not been treated (Nolan, 2008). According to Rubin (2008), this assumption is the main disadvantage of propensity score matching, in that it implies that all relevant observed variables are included in the estimation of the treatment effect, the variables are measured before the treatment assignment and the covariates of the treatment and control group are fully balanced after the matching procedure. The first requirement cannot be tested, but it requires a propensity score that is based on an adequate set of covariates (Sastre et al., 2017). Therefore, sufficient covariates should be used to estimate the propensity score, even if they are statistically insignificant (Millimet and Tchernis, 2009). The conditional independence assumption is somewhat weaker when we compare the CDID estimator against pure matching without differencing (Karhunen and Huovari, 2015), because unobservable differences in characteristics between the treatment and control groups that are constant over time get eliminated when we take the differences of the outcomes (Nolan, 2008). Finally, the common support assumption predicts that the propensity scores of the treatment group fall within the range of the propensity scores of the control group.

We also need to determine how to compute the weights in Equations 1 and 2 . Various matching methods exist, such as nearest neighbour, which is commonly used in innovation domains (Czarnitzki et al., 2007; Herrera and Nieto, 2008), as well as calliper, radius and kernel matching. These matching estimators differ in how they select and weight non-treated firms and in their capacity to trade bias reduction against efficiency in 
estimates (Antonioli et al., 2014; Caliendo and Kopeinig, 2008; Smith and Todd, 2005). Nearest neighbour matching involves finding one or multiple control group observations with the closest propensity scores for each treated observation. Calliper matching is a variant of nearest neighbour matching that improves the quality of matching by imposing a range within which the propensity scores of control observations must lie. With radius matching, all control observations within a specified range enter the estimation. Kernel matching implies that all treated observations match with a weighted average of all controls with weights that are inversely proportional to the distance between the propensity scores of treated and control variables. That is, close matches earn a greater weight, and poor matches take a smaller weight (Becker and Ichino, 2002; Nolan, 2008). Kernel matching is our preferred approach, because of its good finite sample properties and lower variance, due to the inclusion of more information (Caliendo and Kopeinig, 2008; Fröhlich, 2004). A comparison of results obtained with different methods also indicates the stability and robustness of the effects (Antonioli et al., 2014). Noting that Busso et al. (2014) recommend estimating average treatment effects with a variety of approaches, we also complement our kernel matching by estimating the ATT with nearest neighbour matching. The tests and evaluation of the assumptions rely on the PSMATCH2 and PSTEST programs (Leuvin and Sianesi, 2018) in STATA 14.

Because the responses reflect the perceptions of the SME owner or manager, we checked for a potential common method bias, using Harman's one-factor test (Podsakoff et al., 2003). The test indicated that only $28.35 \%$ of the variance is explained by one factor, so no single factor accounts for the majority of the variance. Therefore, our data do not appear to suffer from common method bias.

\section{Results}

Before turning to the estimation results, we compare the characteristics of SMEs that receive a subsidy with those that do not. The results of this probit model in Table 2.2 indicate that the diversity of innovation partners, growth ambition and firm size all significantly affect the selection process. That is, SMEs that cooperate with more diverse innovation partners are more likely to obtain an innovation subsidy. Those that express greater growth ambitions for the next five years also are more likely to receive a subsidy. However, firm size is negatively related to the propensity to receive an innovation subsidy, such that smaller SMEs are more prone to receive one.

Table 2.3 contains the descriptive statistics of the covariates before and after the matching procedure. A comparison of the mean values before matching indicates significant differences between subsidized and unsubsidized SMEs on many of the studied variables. Specifically, for firm age, firm size, the diversity of innovation partners and growth ambition, subsidized and unsubsidized groups display different mean values at the 0.05 significance level, in addition to our dependent variable. The matching procedure attempts to balance these differences in such a way that both groups of SMEs are similar 
in their covariates, with the exception of receiving a subsidy or not (Karhunen and Huovari, 2015). In Table 2.3, the p-values of the covariates after the matching procedure are all insignificant. Therefore, we can conclude that the bias between subsidized and unsubsidized firms is reduced and the matching procedure was successful.

Table 2.2. Probit estimation of the probability of treatment

\begin{tabular}{lcccc}
\hline Variable & \multicolumn{3}{c}{ Coefficient (SE) t-value } \\
\hline Age Firm & 0.024 & $(0.021)$ & 1.18 \\
Age Firm^2 & -0.001 & $(0.001)$ & -1.32 \\
Log Firm Size & -0.304 & $(0.138)$ & $-2.20^{* *}$ \\
Diversity of Innovation Partners & 0.441 & $(0.185)$ & $2.39^{* *}$ \\
Growth Ambition & 0.511 & $(0.218)$ & $2.35^{* *}$ \\
Frontline Expertise & 0.028 & $(0.097)$ & 0.29 \\
Presence of Product Innovation & -0.027 & $(0.432)$ & -0.06 \\
Presence of Process Innovation & -0.422 & $(0.301)$ & -1.40 \\
Constant & -3.729 & $(1.390)$ & $-2.68^{* * *}$ \\
\hline
\end{tabular}

${ }^{*} p<0.1, * * p<0.05, * * * p<0.01$

Notes: The dependent variable is receiving a subsidy in 2014. $N=92$, Pseudo- $R 2=0.19$, Prob $\geq X 2=0.0026$.

Table 2.3. Descriptive statistics of covariates before and after matching

\begin{tabular}{|c|c|c|c|c|c|c|}
\hline \multirow[b]{3}{*}{ Variable } & \multicolumn{3}{|c|}{ Before matching } & \multicolumn{3}{|c|}{ After matching } \\
\hline & \multicolumn{2}{|c|}{ Mean } & \multirow[b]{2}{*}{$p$ value } & \multicolumn{2}{|c|}{ Mean } & \multirow[b]{2}{*}{$p$ value } \\
\hline & $\begin{array}{l}\text { Treatment } \\
\text { group }\end{array}$ & $\begin{array}{l}\text { Control } \\
\text { group }\end{array}$ & & $\begin{array}{l}\text { Treatment } \\
\text { group }\end{array}$ & $\begin{array}{l}\text { Control } \\
\text { group }\end{array}$ & \\
\hline \multicolumn{7}{|l|}{ Outcome variable } \\
\hline \multicolumn{6}{|l|}{ Matching variables } & 0.005 \\
\hline Age Firm & 18.38 & 34.00 & 0.010 & 21.50 & 21.58 & 0.985 \\
\hline Age Firm^2 & 619.83 & 2316.60 & 0.024 & 759.06 & 710.39 & 0.870 \\
\hline Log Firm Size & 2.37 & 3.02 & 0.019 & 2.75 & 2.86 & 0.730 \\
\hline $\begin{array}{l}\text { Diversity of Innovation } \\
\text { Partners }\end{array}$ & 4.53 & 4.02 & 0.005 & 4.41 & 4.41 & 0.996 \\
\hline Growth Ambition & 4.71 & 4.27 & 0.014 & 4.67 & 4.66 & 0.962 \\
\hline Frontline Expertise & 5.08 & 4.90 & 0.605 & 4.88 & 5.08 & 0.595 \\
\hline $\begin{array}{l}\text { Presence of Product } \\
\text { Innovation }\end{array}$ & 0.85 & 0.85 & 0.960 & 0.88 & 0.88 & 0.981 \\
\hline $\begin{array}{l}\text { Presence of Process } \\
\text { Innovation }\end{array}$ & 0.45 & 0.56 & 0.311 & 0.53 & 0.50 & 0.801 \\
\hline Observations & 40 & 52 & & 32 & 52 & \\
\hline
\end{tabular}

Notes: Eight observations were excluded, due to the common support assumption. 
Table 2.4 contains the ATT results from our CDID analysis, for both SMEs that received a subsidy (treatment, $N=32$ ) and SMEs that did not (control, $N=52$ ). By imposing the common support restriction, we removed eight observations from the analysis. Across the different estimators, we find that receiving a subsidy has a consistent, positive effect on employee involvement. The kernel and nearest neighbour estimations range from 0.61 to 0.74 and are all significant, such that the level of employee involvement in subsidized SMEs increases by 0.61 to 0.74 more than in unsubsidized SMES, measured on a 7-point Likert scale. The difference across estimation methods for the selection of the control firms and their respective weighting, combined with the consistent outcomes, also affirms the robustness of our findings.

\section{Additional Analysis}

Although these findings provide insights into the effect of innovation subsidies on employee involvement, we have not made an explicit link with innovation performance. Previous research suggests a positive effect of employee involvement on SME product innovation performance, such that it improves the share of the product innovation as a percentage of total sales and encourages the implementation of process innovations (Andries and Czarnitzki, 2014; Uhlaner, 2013).

To invigorate these findings, we seek to confirm whether this effect arises in our sample. Therefore, we ran another regression analysis, in which we tested the effect of employee involvement on an SME's ability to create a competitive advantage. The dependent variable is the SME's ability to achieve a competitive advantage, through product innovation. The measurement items, obtained from Carbonell et al. (2009), are "Our products give us an important competitive advantage" and "The product experience of our customers was superior to the product experience with competitors." We test the longitudinal effect of the level of employee involvement in 2014 on product innovation performance in 2016, controlling for firm age, firm size and diversity of innovation partners, because firm age and size affect innovation processes (Chapman and Hewitt-Dundas, 2018; Huergo and Jaumandreu, 2004), and research indicates that the diversity of innovation partners can encourage innovation success (Classen et al., 2012; Laursen and Salter,

Table 2.4. Treatment effect on Employee Involvement

\begin{tabular}{|c|c|c|c|c|c|c|c|c|}
\hline \multirow[b]{2}{*}{ Outcome variable } & \multicolumn{2}{|c|}{ Kernel } & \multicolumn{2}{|c|}{$\begin{array}{l}1 \text { - Nearest } \\
\text { Neighbour }\end{array}$} & \multicolumn{2}{|c|}{$\begin{array}{l}2 \text { - Nearest } \\
\text { Neighbour }\end{array}$} & \multicolumn{2}{|c|}{$\begin{array}{l}3 \text { - Nearest } \\
\text { Neighbour }\end{array}$} \\
\hline & ATT & SE & ATT & SE & ATT & SE & ATT & SE \\
\hline $\begin{array}{l}\text { Employee } \\
\text { Involvement }\end{array}$ & $0.74^{* * *}$ & 0.26 & 0.72 ** & 0.34 & 0.67 ** & 0.28 & 0.61 ** & 0.27 \\
\hline$N$ treated & 32 & & 32 & & 32 & & 32 & \\
\hline$N$ control & 52 & & 52 & & 52 & & 52 & \\
\hline
\end{tabular}

${ }^{*} p<0.1,{ }^{* *} p<0.05,{ }^{* * *} p<0.01$. 
2006). Because not all SMEs in our sample innovate, we conduct this regression analysis among a reduced sample of 82 firms. The results in Table 2.5 strongly support previous research that indicates employee involvement has a positive, significant effect on product innovation performance $(\beta=0.221, p=0.012$ ). After adding employee involvement to model 2 , the R-square value increases from 0.10 to 0.17 . Neither firm size nor diversity of innovation partners is significant, which could be a consequence of the low statistical test power, due to the limited number of observations (Berger and Udell, 1995). In summary, we confirm that employee involvement helps SMEs achieve a competitive advantage based on their enhanced product innovation.

\section{Discussion and Conclusion}

Substantial public funding has been devoted to subsidies that aim to support SMEs' innovation projects (Meuleman and De Maeseneire, 2012). Evaluations of public subsidy programs often focus on input and output additionality, but a more recent view suggests that innovation subsidies also might affect an organization's internal behaviour (Buisseret et al., 1995). Yet this behavioural additionality has not been tested frequently in prior empirical studies, and evidence of its existence is largely anecdotal (Cerulli et al., 2016; Clarysse et al., 2009). As a result, the mechanisms by which organizations benefit from innovation subsidies have remained obscure (Roper and Hewitt-Dundas, 2016). In this study, we investigate how policy makers can enhance SME innovation performance by formulating an answer to the first research question:

What impact does receiving an innovation subsidy have on SMEs' employee involvement?

We find that public funds invested in innovation subsidies indeed have a structural impact on the innovativeness of SMEs, because these subsidies result in an increase in the extent to which employees take part in strategic decision-making. Thereby, we

Table 2.5. Additional regression analysis

\begin{tabular}{|c|c|c|c|c|}
\hline \multirow[b]{2}{*}{ Variable } & \multicolumn{2}{|c|}{ Model 1} & \multicolumn{2}{|c|}{ Model 2} \\
\hline & Coefficient & Standard Error & Coefficient & Standard Error \\
\hline Constant & $5.527 * * *$ & 0.590 & $4.547 * * *$ & 0.685 \\
\hline Log Firm Size & 0.115 & 0.094 & 0.113 & 0.091 \\
\hline Age Firm & $-0.012 * * *$ & 0.004 & $-0.012 * * \star$ & 0.004 \\
\hline Diversity of Innovation Partners & 0.031 & 0.128 & 0.007 & 0.124 \\
\hline Employee Involvement & & & $0.221 * *$ & 0.086 \\
\hline N & 82 & & 82 & \\
\hline $\mathrm{R}^{2}$ & 0.102 & & 0.173 & \\
\hline
\end{tabular}

${ }^{*} p<0.1,{ }^{* *} p<0.05,{ }^{* * *} p<0.01$.

Notes: The dependent variable is product innovation performance. 
provide empirical evidence for the newly identified, behavioural additionality effect of receiving an innovation subsidy on the level of employee involvement in an SME. We suggest that innovation subsidies provide SMEs with financial slack, which might allow employees to engage increasingly in strategic decision-making. Previous research also reports that employee involvement benefits SMEs by stimulating product innovation performance (Andries and Czarnitzki, 2014; Uhlaner, 2013); we corroborate this finding with an additional analysis.

Our findings in turn offer several contributions. First, we widen our understanding of behavioural additionality effects. Prior behavioural additionality studies have mostly focused on changes in external collaboration practices after receiving a subsidy, by taking the number of external collaboration partners or the amount of money invested in external collaboration as the unit of analysis (Gök, 2010; Gök and Edler, 2012). Such behavioural additionality research excludes the internal collaboration dynamics (Gök, 2010), and thereby disregards an important unit of analysis (Gök and Edler, 2012). By focusing on the development of employee involvement after receiving an innovation subsidy, we address this overlooked dimension (Gök and Edler, 2012) and broaden understanding of behavioural additionality.

Second, we contribute to SME literature by illuminating how employee involvement can be stimulated through the receipt of an innovation subsidy. Employee involvement evokes positive outcomes related to job satisfaction, organizational performance, climate and commitment in large organizations (Mendes, 2012; Pun and Chin, 1999; Wilkinson, 1998); it is even more important for the success of SMEs, which need all their employees and practices to contribute to performance to overcome their resource limitations. That is, SMEs cannot afford to underutilize their workforce and must rely on those staff members for learning, innovation and creativity (Castrogiovanni, 2011; Rohlfer, 2018). Yet research into the antecedents of employee involvement in SMEs is limited (Rohlfer, 2018). Beyond managerial commitment and extrinsic and intrinsic rewards (Pun et al., 2001), receiving an innovation subsidy can drive such employee involvement, as we reveal herein.

Third, we provide a methodological contribution and respond to calls for longitudinal studies (Autio et al., 2008), preferably using repeat measures from the same projects, that examine the temporal dynamics of behavioural additionality. Most prior studies are cross-sectional; with our longitudinal data set, we could conduct a conditional differencein-difference analysis and tease out the longitudinal effect of receiving an innovation subsidy on employee involvement.

Our findings in turn have implications for policy makers and practitioners. Policy makers need empirical evidence that they have spent public money well (Clarysse et al., 2009), and the revealed relationship between receiving an innovation subsidy and the level of SME employee involvement provides new justification for such innovation policies. Our study shows that innovation subsidies have an unintended positive effect on the development of organizational behaviour, in addition to their documented influence on R\&D investments, innovation outputs and external collaboration. For SME owners, we 
also suggest that subsidies can provide organizations with financial slack resources that in turn grant their employees more opportunities to get involved in strategic decision making and innovation. Such trends positively affect SME innovation performance, and our study corroborates previous research that reports a positive effect of employee involvement on innovation performance (Andries and Czarnitzki, 2014; Uhlaner, 2013).

Our research also has some limitations, due to data availability. First, our sample consists of actual SME owners in the Dutch province of Limburg, reflecting the scope of the LimburgMakers subsidy program. Thus, our sample size is limited. Second, considering the specific geographic region in which we conducted our research, the generalizability of our results is uncertain. Further investigations might extend our findings by evaluating the effect of innovation subsidies on employee involvement within a larger subsidy program or in a different region. Third, this study relied on self-reported, attitudinal data from one source, and few SME owners are willing to disclose their financial performance data (Naman and Slevin, 1993; Poon et al., 2006). Fortunately, subjective and objective performance data generally are highly correlated in SME contexts (Basco, 2014; Dess and Robinson, 1984). Still, continued research might investigate whether the increased employee involvement levels following an innovation subsidy persist for longer time periods. Another avenue for further research would be to address whether other important types of organizational behaviour, such as hiring or training routines, also benefit from receiving a subsidy. 



\section{Chapter

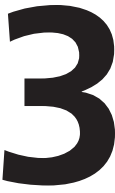 \\ Exploring antecedents of service innovation performance in manufacturing SMEs}

Mennens, K., Van Gils, A., Odekerken-Schröder, G., and Letterie, W. (2018). Exploring antecedents of service innovation performance in manufacturing SMEs.

International Small Business Journal, 36(5), 500-520. 
Chapter 3

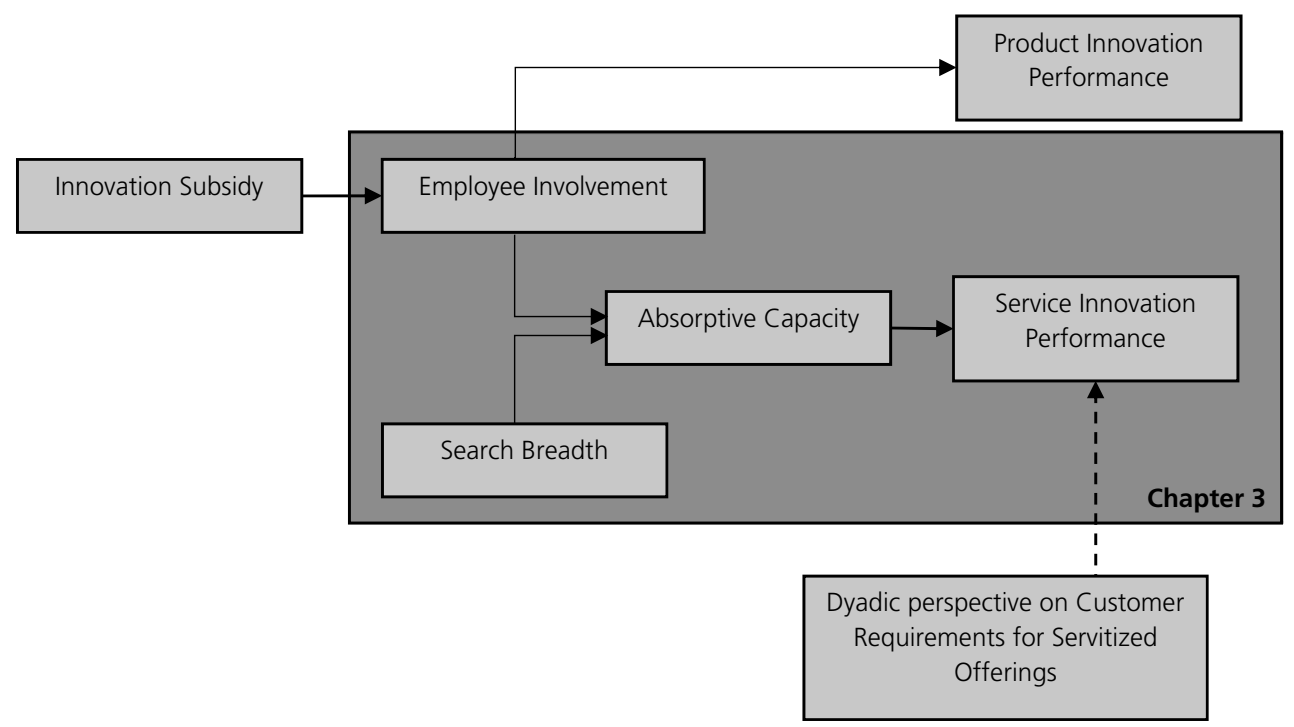

Figure 3.1. Dissertation research model - Focus of chapter 3 


\section{Introduction}

In the previous chapter, we showed how policy-makers can facilitate SME innovation with public subsidy programs. In this chapter, we embrace an intra-organizational perspective and examine how a manufacturing SME can improve its innovation performance. Innovation enables SMEs to grow (Brunswicker and Vanhaverbeke, 2015; European Commission, 2018), and positively affects performance by increasing sales (Hoffman et al., 1998) and long-term survival (He and Wong, 2004; Lubatkin et al., 2006). In short, innovation is a precondition for the competitiveness of SMEs (Madrid-Guijarro et al., 2009). However, today manufacturers faced significant challenges, such as decreasing product margins, in their core product markets (Baines et al., 2009). These challenges impede their ability to achieve a competitive advantage based on product innovation (Story et al., 2017). As a result, many manufacturing companies integrate services as a distinctive feature in their competitive strategy (Matthyssens and Vandenbempt, 2008). The process of creating value by shifting from selling products to selling solutions, that integrate products and services, is known as servitization (Baines et al., 2009). This strategy has been implemented by not just large companies, such as General Electric, IBM, Xerox and Rolls-Royce Aerospace (Kastalli and Van Looy, 2013), but also by small and mediumsized enterprises (SMEs). For example, a small manufacturer of climate control systems for livestock stalls added information technology (IT) services to its products to inform farmers about emergencies, through alerts on their mobile devices. For such servitization efforts to succeed, they demand service innovation (Lightfoot and Gebauer, 2011; Martin and Horne, 1992), which can establish a key competitive advantage (Storey et al., 2016). The ability to achieve a competitive advantage based on service innovations represents service innovation performance (Storey et al., 2016).

Servitizing companies seek to provide better services (Berry et al., 2006), but many businesses fail to innovate their services systematically (Gebauer et al., 2008). Such a failure to achieve service innovation performance (Gebauer et al., 2005; Spring and Araujo, 2009) might occur because firms lack a formal approach to guide their service innovation efforts (Baines et al., 2009; Storey et al., 2016). Empirical studies indicate that few firms use formal approaches to service innovation and instead adopt a haphazard process that simply 'happens' (Gebauer et al., 2008; Lightfoot and Gebauer, 2011). Such firms fail to reap the potential benefits of servitization and potentially suffer negative financial returns (Visnjic et al., 2016). In particular, SMEs are vulnerable to the risks of investing in service innovation as they often lack the resources or experience needed to develop and provide new services (Kowalkowski et al., 2013). In addition, SME ownermanagers usually define the strategic development of their firms, so their own cognitive and affective characteristics imprint upon the full organization (Hermann and Nadkarni, 2014; Zhang et al., 2006), potentially creating a quasi-lock-in situation hampering changes to routines (Liao et al., 2008). Moreover, approximately $70 \%$ of SMEs are family owned, so they often prioritize socio-emotional wealth preservation over business 
renewal (Gómez-Mejía et al., 2007). Changing routines to achieve service innovation would be even more difficult in manufacturing SMEs, which traditionally have attained their competitive advantages through product innovation (Madrid-Guijarro et al., 2009; Maes and Sels, 2014; Raymond and St-Pierre, 2010; Terziovski, 2010).

Studies that investigate how SMEs might excel in their service innovation are relatively scarce (Kowalkowski et al., 2013; Van de Vrande et al., 2009). Some cite key antecedents of service innovation performance, including internal organizational factors, such as proficient operations and delivery systems, a strong innovation culture and appropriate organizational design practices (Atuahene-Gima, 1996; Storey et al., 2016). In addition, we know from the (open) innovation literature that fast-changing environments demand that SMEs cooperate closely with their stakeholders to speed up the innovation process and deliver appropriate products or services (Mina et al., 2014). Yet, we lack insights into how SMEs extract knowledge from these relationships to enhance their service innovation performance. This question is especially relevant for manufacturing firms exploring service opportunities, which can attain success by leveraging external knowledge rather than creating knowledge internally in their R\&D departments (Storey et al., 2016). Challenges to the organization of a firm's knowledge management capabilities, thus, result from the need to recombine different knowledge inputs (Mina et al., 2014). To address these aspects, we formulate an answer to the second research question of this dissertation:

Which organizational mechanisms allow SMEs to achieve service innovation performance?

We commence with a dynamic capabilities perspective as this theory explains how organizations can achieve sustainable competitive advantages in rapidly changing business environments by combining valuable resources into capabilities at the organizational level (Teece et al., 1997). We examine specifically how knowledge management influences service innovation performance. A dynamic capability framework is both appropriate and timely in that manufacturing SMEs confront changing markets, new customer demands, new (often low-cost) competitors and product commoditization (Kindström et al., 2013). Therefore, we study SME absorptive capacity (ACAP) or the ability to recognize and assimilate valuable external knowledge and then apply it to commercial ends (Cohen and Levinthal, 1990). ACAP comprises potential absorptive capacity (PACAP), including knowledge acquisition and assimilation capabilities, and realized absorptive capacity (RACAP), including knowledge transformation and exploitation capabilities (Zahra and George, 2002). ACAP can lead to the creation of a sustainable competitive advantage (Zahra and George, 2002) as it drives product innovation performance (Alegra et al., 2013; Chen et al., 2009; Fosfuri and Tribó, 2008). However, successful product and service innovation have different antecedents (Nijssen et al., 2006), so we cannot simply assume that ACAP leads to service innovation performance. We examine this relationship explicitly herein. 
To enhance knowledge-related capabilities and achieve service innovation performance, SMEs must also establish mechanisms that facilitate the acquisition of knowledge from their dynamic interactions with internal and external partners (Chirico and Nordqvist, 2010; Volberda et al., 2010). External knowledge gained from inter-firm collaborations must combine with existing internal knowledge before it can be applied (Jansen et al., 2005), that is, external knowledge cannot be used effectively without internal collaboration efforts (Benson and Ziedonis, 2009; Rothaermel and Alexandre, 2009). Without the collaboration of employees, ideas that are reaped from the external environment might suffer from the 'not-invented-here' syndrome (Herzog and Leker, 2010; Katz and Allen, 1982). External collaboration, however, is crucial as it provides an opportunity to grasp emerging technologies and markets, thereby complementing the organization's internal knowledge base (Perkmann and Walsh, 2007). In short, both internal and external collaboration mechanisms facilitate the acquisition, assimilation and exploitation of external knowledge. Although the extant literature recognizes that dynamic capabilities encompass collective learning and coordinated efforts by organization members (Helfat and Winter, 2011), the social foundations of these capabilities remain largely unexplored (Fainshmidt and Frazier, 2016; Wilden et al., 2016). Therefore, we also investigate whether internal employee collaboration (i.e. extent to which personnel engage in service innovation) and external collaboration (i.e. search breadth, or the degree of diversity of external innovation partners) affect ACAP and thereby influence SME service innovation performance.

We study the effects of these factors among a sample of Dutch, servitizing, manufacturing SMEs. We find that search breadth and employee collaboration have positive effects on PACAP. Employee collaboration also drives RACAP which in turn drives service innovation performance. The identified mechanism allows us to contribute to the body of literature on service innovation, dynamic capabilities and SMEs. First, we increase our understanding of how service innovation can be facilitated in SMEs and offer theoretical and managerial guidelines on how to reach service-based competitive advantages. We achieve this by demonstrating that internal and external collaboration encourage the development of a dynamic knowledge capability (ACAP), eventually resulting in a competitive advantage based on service innovation. Accordingly, we affirm that although a focus on service innovation demands new mind-sets, operations, strategies and capabilities (Benedettini et al., 2015), building a knowledge base is critical to service innovation, just as it is for product innovation. Second, we substantiate that employee collaboration has a positive impact on the development of dynamic capabilities (ACAP). This finding advances dynamic capabilities literature, which has devoted relatively less attention to the context of SMEs (Kevill et al., 2017), such that it remains unclear what effects organizational members other than managers, such as employees, have on the development of dynamic capabilities (Helfat and Peteraf, 2015). Third, we reveal that SMEs rely on the diversity of their external networks to engage in service innovation. 
As noted, service innovation in SME contexts remains under-researched (Kowalkowski et al., 2013; Van de Vrande et al., 2009); this article provides the novel insight that manufacturing SMEs depend heavily not only on their external networks to extend into service businesses due to their lack of resources but also on the diversity of these networks.

In the next section, we review existing literature and derive our hypotheses. After we describe the sample, measures and data analysis methods, we present our results and the implications of the analysis. We also suggest avenues for further research.

\section{Literature review and hypotheses}

\section{Service innovation performance}

We define service innovation performance as the degree to which an SME achieves a competitive advantage based on service innovation (Storey et al., 2016). Service innovation performance is a critical success factor of servitization (Lightfoot and Gebauer, 2011; Martin and Horne, 1992), such that the search for drivers of service innovation performance started decades ago (De Brentani, 1989) and increased recently (Storey et al., 2016). Factors such as service quality, proficient operations and delivery systems have been identified as antecedents of service innovation performance (Storey and Easingwood, 1998), as have a strong innovation culture and the development of an innovation strategy, which help prioritize the development of new services (Storey et al., 2016). Closely related to this strategic need is the importance of appropriate organizational designs, such as reward structures (Atuahene-Gima, 1996; Storey and Hull, 2010) and the involvement of frontline staff (De Brentani, 1989).

We turn to the dynamic capabilities literature to predict how the combination of internal and external capabilities might facilitate the development of knowledge critical to the service innovation process (Freiling and Dressel, 2015; Lusch et al., 2007). Servicefocused firms succeed by using external knowledge rather than creating knowledge internally (Storey et al., 2016), so knowledge gained from customers (Carbonell et al., 2009; Melton and Hartline, 2010) and other external relations (Storey et al., 2016) enhances service innovation performance. Given that external knowledge must be recognized and assimilated before it can be used to achieve service innovation performance, ACAP likely represents a highly relevant capability to enhance service innovation performance (Storey et al., 2016).

\section{ACAP as a dynamic capability}

Traditional definitions of ACAP note 'the ability to recognize the value of new information, assimilate it, and apply it to commercial ends' (Cohen and Levinthal, 1990, p. 128). Using external knowledge to foster internal innovation (Flatten et al., 2011), ACAP develops cumulatively, is path dependent and builds on existing knowledge (Cohen and Levinthal, 1994). Previous research often includes ACAP as an antecedent of innovation 
performance (Gebauer et al., 2012), noting its benefits for a firm's long-term viability and product innovation (Tsai, 2001; Zahra and George, 2002).

Whereas Cohen and Levinthal (1990) introduce three sequential ACAP processes (identification, assimilation and exploitation), we adopt an approach advanced by Zahra and George (2002), who suggest that ACAP is a dynamic capability, that is, an organizational process and routine by which firms synthesize and acquire knowledge resources and then generate new applications from those resources (Kogut and Zander, 1992). Dynamic capabilities imply an ability to renew, augment and adapt a core competence over time (Teece et al., 1997). Therefore, ACAP consists of four complementary dimensions that build on one another (Zahra and George, 2002). Acquisition refers to the ability to discover and obtain relevant external information. It describes whether an organization knows where potential sources of information are located (Fosfuri and Tribó, 2008). The assimilation dimension refers to an organization's routines and processes that allow it to analyse, process, interpret and comprehend the information obtained from external parties. Transformation entails an ability to modify and adapt external knowledge in such a way that it can be combined with existing internal knowledge. Exploitation refers to an ability to apply the transformed knowledge in the organization's operations. Zahra and George (2002) also divide the process into two sections: PACAP, which consists of the first two dimensions, and RACAP, which comprises the latter two dimensions.

The extant literature addresses the positive relationship between ACAP and product innovation performance (Alegra et al., 2013; Chen et al., 2009; Fosfuri and Tribó, 2008; Tsai, 2001). However, the different antecedents of product and service innovation performance (Nijssen et al., 2006) prevent a basic assumption that ACAP also leads to service innovation performance. Acquisition and assimilation are required to identify, capture and process relevant external knowledge to enhance service innovations, but ACAP only leads to a competitive innovation advantage if the knowledge subsequently gets transformed and exploited (Fosfuri and Tribó, 2008). These two processes together form an organization's RACAP (Zahra and George, 2002). For example, scientific knowledge from a university or research institute can facilitate the identification of a new target market or market segment, or it can be a source of radical innovations (Tether, 2002). Scientific knowledge can also increase SME managers' awareness of the possibilities of new business models and technological developments (Bishop et al., 2011). Collaborations with universities might serve to build additional knowledge-based networks (Dada and Fogg, 2016). The resulting knowledge helps firms address customer needs and respond more quickly to market opportunities (Slater and Narver, 1995). Knowing about customer needs also leads to better service quality (Voss et al., 1992), and competitor knowledge can be a source of benchmarking and best practices (Drew, 1997). Exploiting such external knowledge produces competitive advantages, including those achieved with service innovations (Lusch et al., 2007). But this external knowledge cannot be used effectively without internal collaboration (Benson and Ziedonis, 2009; Rothaermel and Alexandre, 
2009). In short, firms succeed in service innovation by combining external knowledge with existing internal knowledge and applying the transformed knowledge (Jansen et al., 2005; Storey et al., 2016). Being able to transform and exploit external knowledge (RACAP) should have a positive effect on service innovation performance:

H1. An SME's RACAP positively influences service innovation performance.

\section{Employee collaboration}

Kleinbaum and Stuart (2014) stress the importance of employee social interactions for the firm's ability to adapt and coordinate changes in its resource base. In other words, the proliferation of dynamic capabilities depends on the behaviour, willingness and ability of employees to act (Schein, 2004; Wilden et al., 2016). Knowledge of employees only translates into ACAP if social interaction patterns enable these employees to engage in the transformation of new knowledge (Hotho et al., 2012). In other words, mechanisms that encourage employees to facilitate the exchange, transformation and exploitation of knowledge (Vega-Jurado et al., 2008). In a similar vein, Jansen et al. (2005) conceptualize employee participation in decision-making as a determinant of an organization's PACAP. It enhances a firm's acquisition and assimilation capabilities, in the form of an increased number of employees who function as 'receptors' in the innovative environment (Cohen and Levinthal, 1990). These receptors scan the external environment and then filter and facilitate the acquisition of new external knowledge (Aldrich and Herker, 1977). Such employee collaboration is particularly critical in a service innovation domain because contact personnel provide the most important interface for gathering external knowledge (Atuahene-Gima, 1996). In particular, high levels of collaboration with service employees increase the amount of information collected about customer problems (Kelley, 1993); these employees represent internal organizational resources that the firm can use to gather and assess necessary information to create successful new services (Melton and Hartline, 2013). Employees, thus, are key to gathering, enabling and interpreting relevant external knowledge that can lead to new service innovations (Melton and Hartline, 2013).

Moreover, employee collaboration in decision-making is shown to affect the organization's RACAP by increasing its abilities to transform new external knowledge (Jansen et al., 2005). As Cohen and Levinthal (1990) argue, interactions among people with diverse knowledge structures augment the organization's capacity to establish novel linkages and associations. Dynamic capability theory similarly posits that including functionally distinct employees, such as contact employees, in the innovation process contributes to successful knowledge creation (Eisenhardt and Martin, 2000). Interactions among employees who possess varying forms of knowledge improve the organization's ability to transform external knowledge. As we noted previously, external knowledge cannot be used effectively without an ability to share the knowledge internally (Benson and Ziedonis, 2009; Rothaermel and Alexandre, 2009). Schneider and Bowen (1984) also 
argue that collaboration with contact employees facilitates innovation implementation because it helps the organization exploit opportunities and create successful new services (De Clercq et al., 2015; Melton and Hartline, 2013). Thus, employee collaboration increases an organization's ability to transform and exploit external knowledge:

H2. Employee collaboration positively influences an SME's (a) PACAP and (b) RACAP.

\section{Search breadth}

Collaborative competence with external actors enhances the comprehension of knowledge from the wider environment (Lusch et al., 2007). According to dynamic capability theory, strong alliance processes grant access to external knowledge and thereby drive superior performance (Eisenhardt and Martin, 2000). Teece (2007) also underscores the importance of broad-based, external knowledge searches, such as from universities, competitors and suppliers. Inter-firm relationships can spur the creation, sharing and exploitation of knowledge (Masiello et al., 2015) and thus constitute antecedents of ACAP (Cohen and Levinthal, 1990; Fosfuri and Tribó, 2008; Zahra and George, 2002). Gaining knowledge from external sources and learning from partners are critical interorganizational antecedents of ACAP for SMEs (Geneste and Galvin, 2013; Volberda et al., 2010). In short, the external linkages of an organization exert important impacts on how ACAP, as a dynamic capability, evolves (Teece et al., 1997). Organizations also use the knowledge from various external partners for different purposes (Mina et al., 2014; Teece, 1980). An SME's search breadth, or the diversity of its external innovation partners, enhances its propensity to acquire external knowledge (Van Wijk et al., 2001). The more diverse the interactions with external knowledge sources, the greater the experiential learning accumulated by the organization, which makes the assimilation process simpler (Fosfuri and Tribó, 2008). Openness to external sources also enables organizations to identify and acquire ideas in the external environment and increases the opportunities available to them; too much of an internal focus may result in missed opportunities (Laursen and Salter, 2006). Therefore, diversity in an SME's portfolio of external partners is highly valued (Love and Roper, 2015). Search breadth enhances its abilities to acquire and assimilate knowledge from diverse partners, due to experiential learning, so we predict that greater search breadth results in better developed acquisition and assimilation capabilities (Figure 3.2):

H3. Search breadth positively influences an SME's PACAP.

\section{Research methodology}

\section{Sample and data characteristics}

The items for this study were included in a larger questionnaire that evaluated the innovativeness of manufacturing SMEs. Data came from Dutch manufacturing 


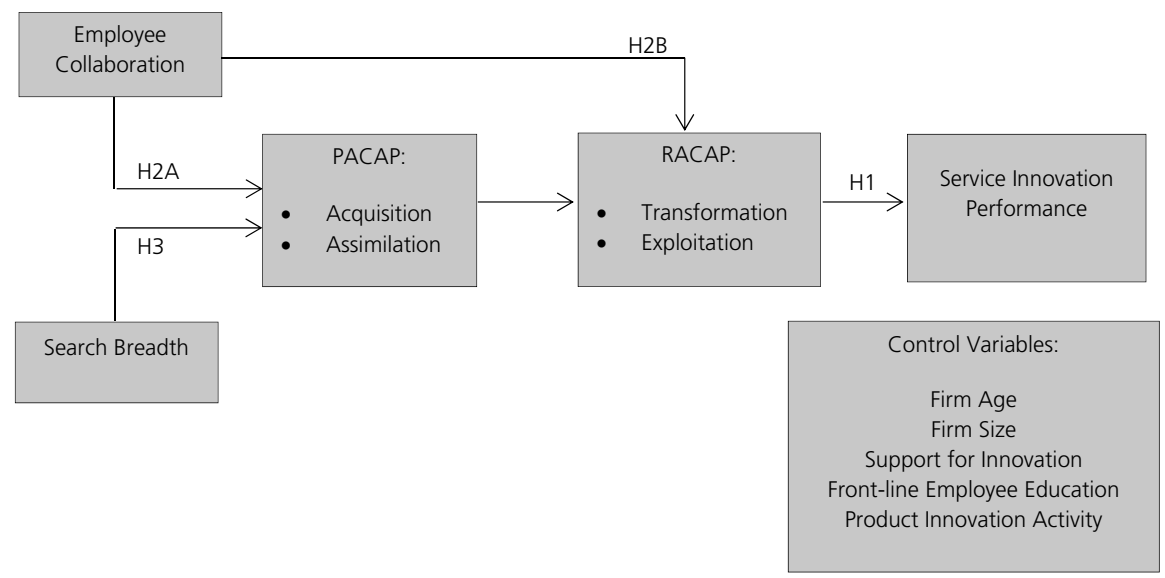

Figure 3.2. Structural model

SMEs in the southern provinces of the Netherlands. We defined an organization as an SME if it had fewer than 250 employees, in line with the European Union definition. The questionnaire was first sent to 1711 SMEs via email, which contained a link to an online survey. If we received no answer, we sent a reminder email. Following no response, we then sent a reminder letter by postal mail, including a printed survey and a reply envelope. In total, 246 organizations answered the survey, for a response rate of $14.4 \%$, which is normal for this type of research (Baum et al., 2001; Moreno and Casillas, 2008; Wiklund and Shepherd, 2005; Zahra and Garvis, 2000). Our investigation focuses on how SMEs can achieve service innovation performance, and only 121 SMEs indicated that they had implemented at least one service innovation in the past year. In other words, $49 \%$ of the SMEs in the overall sample implemented at least one service innovation in the past year - a seemingly small percentage, considering the advantages SMEs can obtain through service innovation. After deleting 21 observations because of missing values or not meeting the sample criteria, we obtained a final data set of 100 respondents.

We checked for the potential selection bias that may arise because only SMEs that already servitize are included. Specifically, we applied the two-step approach by Heckman (1979) three times, one for each endogenous variable. For each analysis, the inverse Mill's ratio was highly insignificant ( $p$-values: $0.31,0.47$ and 0.77 for PACAP, RACAP and service innovation performance, respectively), which suggests that selection bias is not a concern for this study. To check for nonresponse bias, we conducted a t-test of the differences between early and late responses (Armstrong and Overton, 1977). We found no significant differences for any of the relevant variables at the 0.05 significance level. 


\section{Measures}

Service innovation performance. To operationalize service innovation performance, we use scales from Carbonell et al. (2009), who adapted De Brentani's (1989) measures to assess the competitive superiority of new services. Three items determine the performance of service innovations that actually came to market, such as 'Our customer solutions are superior to those of our competitors' and 'Our new services give us an important competitive advantage'. We rely on self-reported measures because SME owners tend not to disclose their financial performance data (Naman and Slevin, 1993; Poon et al., 2006). Furthermore, research shows that subjective and objective performance data are highly correlated, especially in SME contexts (Basco, 2014; Dess and Robinson, 1984; Hoffmann et al., 2016). The expected outcome of dynamic capabilities is the achievement of a competitive advantage (Helfat et al., 2009; Teece et al., 1997), so this comparative measure, relative to competition, fits our study context. Table 3.1 contains the full list of items.

ACAP. Muscio (2007) and Volberda et al. (2010) note a lack of consensus about how to conceptualize and measure ACAP, especially for SMEs, because a conventional proxy uses R\&D (Zahra and George, 2002), but R\&D activity among SMEs tends to be minimal (Whittaker et al., 2016). Jansen et al. (2005) propose a scale to measure ACAP that distinguishes PACAP (acquisition and assimilation) from RACAP (transformation and exploitation) (Zahra and George, 2002). Although acquisition and assimilation form PACAP, they are clearly distinct dimensions. Because acquisition and assimilation do not share a high mutual correlation and measure different capabilities, we regard PACAP as a reflective-formative, second-order construct (Becker et al., 2012; Cepeda-Carrion et al., 2012; Wilden et al., 2013). That is, acquisition and assimilation are measured reflectively, but the two dimensions formatively constitute PACAP. The same logic applies to RACAP. We use Jansen et al.'s (2005) scale but exclude three items from the acquisition dimension that did not fit our SME context: 'Our unit has frequent interactions with corporate headquarters to acquire new knowledge', 'Employees of our unit regularly visit other branches' and 'Other divisions of our company are hardly visited'. Thus, we measure acquisition and assimilation with three items each; the transformation and exploitation dimensions are measured by six items each.

Employee collaboration. With a three-item scale from Ordanini and Parasuraman (2011), we measure the extent to which contact personnel engage in the service innovation process, adapted to represent participation of employees in the development of new strategies, priorities and services. For example, a survey item was, 'Employees are actively engaged in establishing goals and priorities for our strategies'.

Search breadth. Similar to Classen et al. (2012) and Hewitt-Dundas and Roper (2017), we follow Laursen and Salter (2006), who conceptualize search breadth as the number of external partners with which organizations cooperate in an innovation context. Five types of external innovation partners appear in our questionnaire: customers, suppliers, competitors, universities or knowledge institutions and the public sector or government. 
These five binary variables take a value of 1 if the SME makes a connection with that type of external innovation partner, and 0 otherwise. Search breadth then equals the sum of these five binary variables.

Control variables. We include firm age as a control variable; existing research shows that older firms engage in less innovation (Huergo and Jaumandreu, 2004). Furthermore, we control for SME size, measured by the number of employees as full-time equivalents. Size affects the innovativeness of SMEs by influencing their ability to finance innovationrelated investments (Berchicci et al., 2016; Nooteboom, 1994). We control for support for innovation, measured by an item that indicates, 'assistance in developing new ideas is readily available' (Anderson and West, 1998). In doing so, we account for the importance of support when it comes to achieving service innovation performance (Storey et al., 2016). Also, we include the level of education of front-line employees who provide the service.

Table 3.1. Measurement Scales

\begin{tabular}{|c|c|c|}
\hline \multicolumn{3}{|c|}{ Absorptive Capacity } \\
\hline \multicolumn{2}{|c|}{ Source: Jansen et al. (2005), 7-point Likert scale } & Loadings \\
\hline \multicolumn{3}{|c|}{ PACAP } \\
\hline \multicolumn{3}{|c|}{ Acquisition } \\
\hline Ac 1 & $\begin{array}{l}\text { Our organization collects industry information through informal means } \\
\text { (e.g. lunch with industry friends, talks with trade partners). }\end{array}$ & 0.67 \\
\hline Ac 2 & $\begin{array}{l}\text { Our organization periodically organizes special meetings with customers } \\
\text { or third parties to acquire new knowledge. }\end{array}$ & 0.79 \\
\hline Ac 3 & $\begin{array}{l}\text { Employees regularly approach third parties such as accountants, } \\
\text { consultants or tax consultants. }\end{array}$ & 0.77 \\
\hline \multicolumn{3}{|c|}{ Assimilation } \\
\hline As 1 & $\begin{array}{l}\text { Our organization is slow to recognize shifts in our market (e.g. } \\
\text { competition, regulation, demography). (reverse-coded) }\end{array}$ & 0.76 \\
\hline As 2 & New opportunities to serve our clients are quickly understood. & 0.87 \\
\hline As 3 & $\begin{array}{l}\text { Our organization quickly analyses and interprets changing } \\
\text { market demands. }\end{array}$ & 0.84 \\
\hline \multicolumn{3}{|c|}{ ( } \\
\hline \multicolumn{3}{|c|}{ Transformation } \\
\hline $\operatorname{Tr} 1$ & $\begin{array}{l}\text { Our organization regularly considers the consequences of changing } \\
\text { market demands in terms of new products and services. }\end{array}$ & Eliminated \\
\hline $\operatorname{Tr} 2$ & $\begin{array}{l}\text { Employees record and store newly acquired knowledge for } \\
\text { future reference. }\end{array}$ & 0.77 \\
\hline $\operatorname{Tr} 3$ & $\begin{array}{l}\text { Our organization quickly recognizes the usefulness of new external } \\
\text { knowledge to existing knowledge. }\end{array}$ & 0.78 \\
\hline $\operatorname{Tr} 4$ & Employees hardly share practical experience. (reverse-coded) & Eliminated \\
\hline $\operatorname{Tr} 5$ & $\begin{array}{l}\text { We laboriously grasp the opportunities for our unit from new external } \\
\text { knowledge. (reverse-coded) }\end{array}$ & 0.60 \\
\hline $\operatorname{Tr} 6$ & $\begin{array}{l}\text { In our organization, we periodically meet to discuss consequences of } \\
\text { market trends and new product development. }\end{array}$ & 0.68 \\
\hline
\end{tabular}


Table 3.1. (continued)

\begin{tabular}{|c|c|c|}
\hline \multicolumn{3}{|c|}{ Exploitation } \\
\hline Ex 1 & It is clearly known how activities within our unit should be performed. & Eliminated \\
\hline Ex 2 & Client complaints fall on deaf ears in our organization. (reverse-coded) & 0.73 \\
\hline Ex 3 & Our organization has a clear division of roles and responsibilities. & 0.56 \\
\hline Ex 4 & We constantly consider how to better exploit knowledge. & 0.85 \\
\hline Ex 5 & $\begin{array}{l}\text { Our unit has difficulty implementing new products and services. } \\
\text { (reverse-coded) }\end{array}$ & Eliminated \\
\hline Ex 6 & Employees have a common language regarding our products and services. & Eliminated \\
\hline \multicolumn{3}{|c|}{ Service Innovation Performance } \\
\hline \multicolumn{2}{|r|}{ Sources: De Brentani (1989) and Carbonell et al. (2009), 7-point Likert scale } & Loadings \\
\hline \multicolumn{2}{|r|}{$1 \quad$ Our new services give us an important competitive advantage. } & 0.96 \\
\hline \multicolumn{2}{|r|}{$\begin{array}{l}\text { Our customers experience our new services as superior to those of } \\
\text { our competitors. }\end{array}$} & 0.97 \\
\hline \multicolumn{2}{|r|}{ Our customer solutions are superior to those of our competitors. } & 0.95 \\
\hline \multicolumn{3}{|c|}{ Employee collaboration } \\
\hline \multicolumn{2}{|r|}{ Source: Ordanini and Parasuraman (2011), 7-point Likert scale } & Loadings \\
\hline 1 & $\begin{array}{l}\text { Employees are actively engaged in generating and screening ideas for } \\
\text { new services. }\end{array}$ & 0.77 \\
\hline 2 & $\begin{array}{l}\text { Employees are actively engaged in establishing goals and priorities for } \\
\text { our strategies. }\end{array}$ & 0.86 \\
\hline 3 & $\begin{array}{l}\text { Employees are adequately represented on project teams and other } \\
\text { strategic activities. }\end{array}$ & 0.88 \\
\hline
\end{tabular}

To measure this control variable, we asked the respondents to indicate the extent to which they agree with the statement, 'Front-line employees are highly educated'. Finally, we control for whether the SMEs engaged in product innovation activity, as this could have an impact upon the endogenous variables in the conceptual model.

\section{Analysis}

We used partial least squares structural equation modelling (PLS-SEM) to test the model and hypotheses. As a multivariate analysis technique, PLS enables researchers to examine latent and manifest variables simultaneously (Fornell, 1987). This method is particularly useful when analysing sources of competitive advantage (Hair et al., 2012), and PLS-SEM is appropriate for this study for several reasons. First, it can deal with non-normal data (Chin, 1998; Hair et al., 2012). Hair et al. (2012) advise conducting Kolmogorov-Smirnov or Shapiro-Wilk tests to assess whether data are normally distributed; both tests indicate that our variables are non-normally distributed. We also check for skewness and kurtosis, following the general guidelines (Hair et al., 2016), and thus confirm that our data are non-normally distributed. Second, PLS-SEM can deal with small sample sizes (Chin, 1998; 
Hair et al., 2012). Our final sample size of 100 respondents is comparable to the sample size of Wilden et al. (2013) who use PLS-SEM for a similar study. Hair et al. $(2016,2012)$ offer minimum sample size requirements for PLS-SEM research to detect different R2values at a $5 \%$ significance level while still accounting for the complexity of the PLS path model (i.e. maximum number of arrows pointing at a construct). For this research, the maximum number of arrows is five, so we need 45 observations to identify R2 values of at least 0.25 at a $5 \%$ significance level. Thus, our sample is sufficiently large. Third, PLS-SEM can handle both reflective and formative constructs (Hair et al., 2012; Henseler et al., 2009). In addition to the reflective constructs, such as employee collaboration, we measure PACAP and RACAP as reflective-formative constructs, similar to the operationalization of dynamic capabilities by Wilden et al. (2013). For these reasons, we use PLS-SEM and, specifically, apply SmartPLS 3.0 to conduct the analyses (Ringle et al., 2015). Our model assessment consists of two steps. First, we evaluate the measurement, or outer, model, which connects manifest variables to their latent variables. We use a standard PLS-SEM algorithm and settings and apply case-wise deletion for missing values. Second, we test the structural model, which reveals the relationships among latent variables (Fornell and Larker, 1981; Hulland, 1999).

\section{Results}

\section{Measurement model}

To ensure construct reliability, we check the item loadings and composite reliability values. First, for individual item reliability, we note the loadings. A common rule of thumb is that item loadings should be 0.7 or higher (Hair et al., 2016), although Hulland (1999) acknowledges that several items in an estimated model may have loadings below this threshold, especially for newly developed scales or existing scales transferred to a new context. Items with loadings between 0.40 and 0.70 thus should be considered for removal only if their deletion increases the composite reliability or average variance extracted (AVE) (Hair et al., 2016). With these criteria, we delete two items with loadings less than 0.4 from the exploitation dimension of RACAP, two items from the transformation dimension and one item from the exploitation dimension of RACAP, which improved the composite reliability and AVE values. All other items are retained. Because Jansen et al.'s (2005) scale originally was developed for large organizations, the low item loadings of several items might reflect our SME study context. For construct reliability, Hair et al. (2016) recommend relying on the composite reliability score in PLS-SEM research, although Cronbach's alpha is a more common measure of internal consistency. Unlike Cronbach's alpha, though, composite reliability does not assume that all indicators are equally reliable. Furthermore, Cronbach's alpha is sensitive to the number of items in the scale (Hair et al., 2011, 2016). As Table 3.2 reveals, the composite reliability is above the recommended threshold of 0.7 for all latent variables.

The measure of convergent validity uses the AVE, which should be greater than 0.5 (Bagozzi and Yi, 1988; Hair et al., 2016). The lowest AVE we find is 0.51, so this condition 
is satisfied for all our constructs. In turn, we regard the internal consistency of each construct as sufficient. To ensure discriminant validity, each construct also must share more variance with its measures than with any other constructs, as indicated by a higher square root of the AVE for each construct compared with its correlations with other constructs (Fornell and Larker, 1981; Hair et al., 2016). The square root of the AVE also should have a value of at least 0.7 (Chin, 1998). As Table 3.3 shows, all the constructs met these criteria; this implies the presence of discriminant validity.

To assess the second-order formative ACAP construct, we test for the multicollinearity of its formative indicators, that is, the first-order reflective constructs acquisition, assimilation, transformation and exploitation (Diamantopoulos et al., 2008; Henseler et al., 2009). The variance inflation factors do not exceed 1.949, which is well below the commonly accepted threshold of 5 (Hair et al., 2016). Furthermore, the formative indicators are all significant, with weights between 0.437 and 0.810 . Therefore, we verify the validity of the second-order formative construct.

Both our dependent and independent variables come from the same source, so common method bias could be a potential threat (Podsakoff et al., 2003). Therefore, we conduct two statistical analyses to assess the degree to which a common method bias is present. First, Harman's single-factor test indicates that only $23.86 \%$ of the variance is explained, so no single factor accounts for the majority of variance. Second, we follow a procedure developed specifically for PLS research by Liang et al. (2007; see also Lanero et al., 2016; Lechner and Gudmundsson, 2014) and create a common method factor that includes the indicators of all constructs in the model (Podsakoff et al., 2003; Williams et al., 2003). Next, we compute how much of the variance for each indicator can be attributed to the principal construct and the method factor. Only 3 of the 24 method factor loadings

Table 3.2. Reliability, Validity and Measurement Model

\begin{tabular}{|c|c|c|c|c|}
\hline Reflective Factor & $\begin{array}{l}\text { Number } \\
\text { of Items }\end{array}$ & $\begin{array}{l}\text { Range of } \\
\text { Loadings }\end{array}$ & $\begin{array}{l}\text { Average } \\
\text { Variance Extracted }\end{array}$ & $\begin{array}{l}\text { Composite } \\
\text { Reliability }\end{array}$ \\
\hline Employee Collaboration & 3 & $0.77-0.88$ & 0.71 & 0.88 \\
\hline Acquisition & 3 & $0.66-0.79$ & 0.55 & 0.78 \\
\hline Assimilation & 3 & $0.76-0.87$ & 0.68 & 0.86 \\
\hline Transformation & 4 & $0.60-0.78$ & 0.51 & 0.80 \\
\hline Exploitation & 3 & $0.56-0.85$ & 0.52 & 0.76 \\
\hline $\begin{array}{l}\text { Service Innovation } \\
\text { Performance }\end{array}$ & 3 & $0.95-0.97$ & 0.92 & 0.98 \\
\hline Formative Factor & \multicolumn{2}{|c|}{ Number of Items } & Range of Weights & $\begin{array}{l}\text { Variance } \\
\text { Inflation Factors }\end{array}$ \\
\hline PACAP & \multicolumn{2}{|l|}{2} & $0.437-0.810$ & $1.215-1.401$ \\
\hline RACAP & \multicolumn{2}{|l|}{2} & $0.473-0.642$ & $1.910-1.949$ \\
\hline
\end{tabular}




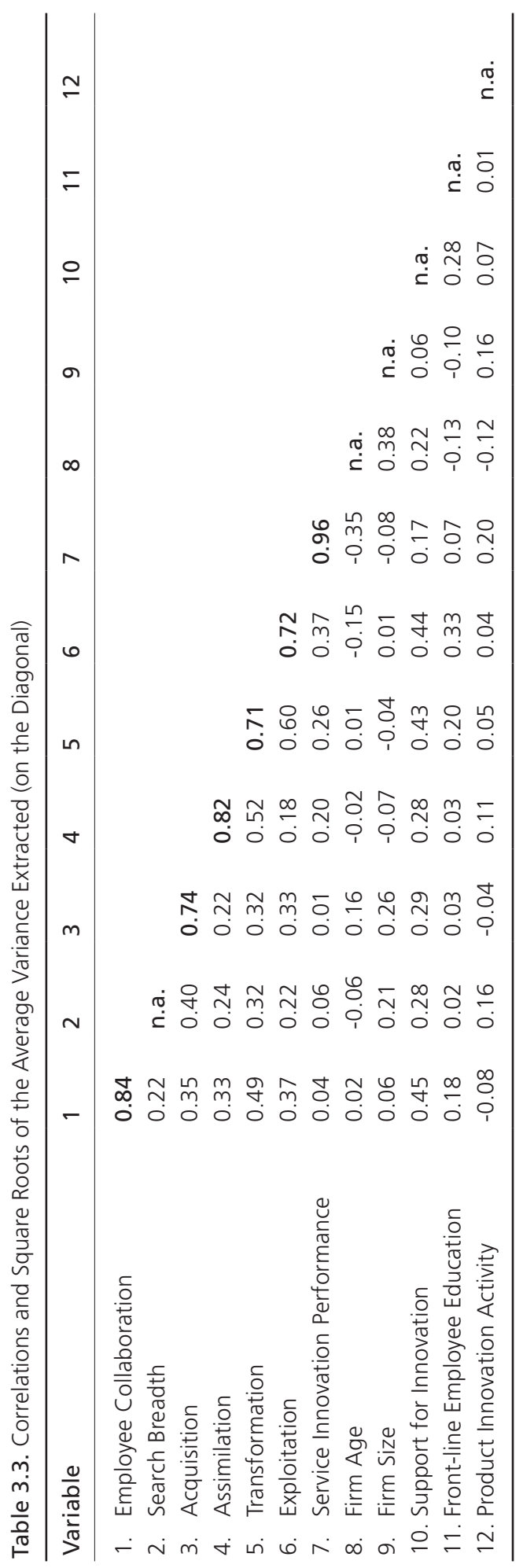


are significant, and the substantive variances of the indicators are substantially greater than their method variances. Therefore, common method bias is not a concern for this study. Because the conditions for the measurement model all are satisfied, we turn our focus to the structural model.

\section{Structural model}

To evaluate the structural model, we use the R2 values of the dependent variables: 0.33 for PACAP, 0.41 for RACAP and 0.25 for service innovation performance, all well above the commonly accepted thresholds set by Falk and Miller (1992), Chin (1998) and Hair et al. (2011). These values are also comparable to those in existing PLS research in SME contexts (e.g. Brettel and Rottenberger, 2013; Sousa et al., 2014). We determine the significance of the coefficients according to 5000 bootstrap samples (Hair et al., 2011). Among the control variables - firm age, firm size, support for innovation, frontline employee education and product innovation activity - only firm age has a negative significant effect on service innovation performance. Younger firms are able to achieve higher service innovation performance.

In line with our first hypothesis, an SME's RACAP has a positive effect on service innovation performance $(=0.267, p<0.05)$. Although we did not formulate an explicit hypothesis about the link between PACAP and RACAP, our results indicate that PACAP has a significant effect on RACAP at the $0.1 \%$ significance level $(=0.427, p>0.001)$. This finding concurs with previous research models that depict ACAP as a sequential process, where RACAP builds on PACAP (Todorova and Durisin, 2007; Volberda et al., 2010; Zahra and George, 2002). Consistent with $\mathrm{H} 2 \mathrm{a}$, employee collaboration has a positive influence on an SME's PACAP $(=0.395, \mathrm{p}<0.001)$, and as we predicted in $\mathrm{H} 2 \mathrm{~b}$, it also has a positive effect on an SME's RACAP $(=0.314, p<0.01)$. Finally, an SME's search breadth relates positively to its PACAP, in support of $\mathrm{H3}(=0.342, \mathrm{p}<0.01)$ (Figure 3.3).

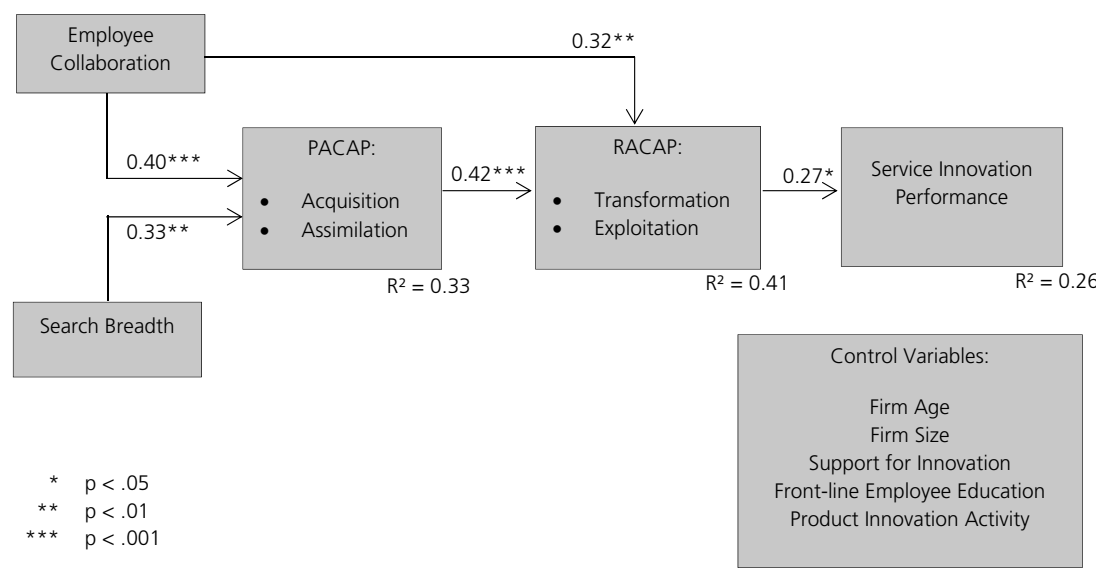

Figure 3.3. Results 


\section{Robustness check}

Some items from the transformation and exploitation dimension were omitted from the analysis because these items had low loadings or their deletion improved the AVE and composite reliability. To check whether this affected the final results of this study, an extra analysis including all previously omitted ACAP items was conducted. None of the hypothesized relationships significantly changed after adding the items, strengthening the support for our results.

\section{Discussion and conclusion}

In manufacturing industries, SMEs are increasingly focused on servitization strategies (Visnjic et al., 2016). Despite their concerted efforts, most firms fail to deliver service innovations effectively and do not achieve the expected servitization benefits (Neely, 2008; Visnjic et al., 2016). Given that service innovations offer an important way to retain or gain competitive advantages (Storey et al., 2016), it is important to find ways for manufacturing SMEs to deliver service innovations more successfully. This study was conducted from an intra-organizational SME perspective to reveal how SMEs can improve their innovation performance by answering the second research question of this dissertation:

Which organizational mechanisms allow SMEs to achieve service innovation performance?

Using a dynamic capabilities perspective, we empirically investigate ACAP as a potential antecedent of service innovation performance in SMEs, as well as how an SME's search breadth, through its effect on PACAP, and employee collaboration, through its effects on both PACAP and RACAP, can drive service innovation performance. We find support for all our hypotheses. Using external knowledge, through RACAP, has a positive effect on service innovation performance, so a manufacturing SME can achieve service innovation performance if it has the capability to transform and exploit relevant external knowledge it has acquired and assimilated. Collaboration with employees in the innovation process also drives service innovation performance by augmenting all dimensions of ACAP. More diverse innovation partners affect service innovation performance too, through its impact on PACAP.

These findings offer several contributions to theory. First, they help increase our understanding of how manufacturing SMEs can achieve service innovation performance and provide theoretical and managerial guidelines of how to reach a service-based competitive advantage. We do this by showing how internal and external collaboration drive the development of a dynamic knowledge capability, which in turn leads to a competitive advantage based on service innovation. Our findings provide empirical support for Storey et al.'s (2016) suggestion that ACAP is an important driver of service innovation performance. Some scholars suggest that dynamic capabilities are required 
for the early phases of initiating servitization, but research into the effect of dynamic capabilities, as a critical success factor for servitization performance, is missing (Kanninen et al., 2017). To address this gap, we show that ACAP as a dynamic capability drives service innovation performance. In so doing, we also contribute to the debate about whether successful servitization requires a radical change in the way organizations think about their operations and value delivery (Gaiardelli et al., 2015). Many organizations fail to servitize successfully, and the key factors that lead to product innovation performance differ from those that lead to service innovation success (Nijssen et al., 2006), prompting some researchers to propose that servitization demands a new approach (Benedettini et al., 2015). For example, Storey et al. (2016), claim that 'servitizing manufacturing firms need to adapt their innovation practices and capabilities to recognize the differences between services and products' (p. 19). Without denying the differences, our results demonstrate that similar knowledge mechanisms drive both types of innovation. Previous research already confirms the positive influence of ACAP on product innovation (Alegra et al., 2013; Chen et al., 2009; Fosfuri and Tribó, 2008; Tsai, 2001); we show that ACAP also drives service innovation performance. The importance of developing and increasing the firm's knowledge base thus does not change in relation to servitization processes. Rather, the main differences may involve the nature of the external knowledge that gets acquired, assimilated, transformed and exploited. Because services are intangible, the relevant knowledge tends to be more tacit and difficult to manage (BlindenbachDriessen and Ende, 2014).

Second, we substantiate that employee collaboration has a positive impact on the development of a dynamic knowledge capability (ACAP). This finding advances the dynamic capabilities literature, where less attention has been devoted to the context of SMEs (Kevill et al., 2017) and which has focused predominantly on organization-level outcomes (Battisti and Deakins, 2017; Rice et al., 2015; Vickers and Lyon, 2014). We illustrate that in an SME context, ACAP is a sequential process, such that RACAP builds on PACAP. Prior research also reveals increasing consideration of a microfoundations perspective on dynamic capabilities, and the role of managers in particular (Helfat and Peteraf, 2015; Kevill et al., 2017; Wilden et al., 2016; Winter, 2013). However, in addition to managers, other organizational actors affect the development of dynamic capabilities too (Helfat and Peteraf, 2015). In support of this assertion, we show that it is not just managers but also employees who have important roles for the development of dynamic capabilities. Dynamic capabilities depend on the ability of organizational members to act (Wilden et al., 2016), as reflected in the link between employee collaboration in the service innovation process and ACAP as a dynamic capability.

Third, we extend SME service innovation literature. Relatively little research has considered service innovation in an SME context (Kowalkowski et al., 2013; Van de Vrande et al., 2009), and that which does reveals that manufacturing SMEs depend heavily on actors in their network to extend into the service business, because of their 
lack of resources. We contribute to this literature by detailing how SMEs rely on their diverse networks. An SME's external knowledge acquisition and assimilation capabilities depend on the diversity of its innovation partners. In this sense, we provide an initial response to a question posed by Mina et al. (2014): 'An important question remains as to whether openness (in the service innovation process) translates into superior market performance' (p. 863). We show that a more diverse set of innovation partners leads to the development of PACAP. In turn, PACAP is positively associated with RACAP, ultimately leading to a competitive advantage based on service innovation.

The analysis also has implications for SME management and policy-makers. Service innovations can help manufacturing SMEs retain their competitive advantage even when products become increasingly commoditized (Chesbrough, 2011). The existing literature proposes that servitization is the best strategy for manufacturing organizations to escape the commodity trap (Chesbrough, 2011), but to outperform competitors through service innovation, they must develop or enhance their ACAP. Having employees who can participate actively in the service innovation process and increasing the diversity of external partners, also offer key means to develop ACAP and indirectly improve service innovation performance.

Given that service innovations can help firms retain their competitive advantages (Chesbrough, 2011), subsidies aimed at stimulating service innovation represent an effective policy for strengthening local manufacturing. Investing in SME capacity to acquire, assimilate, transform and exploit external knowledge can spur service innovation performance. In particular, if SMEs lack information about potential partners and the benefits of cooperation with a diverse set of partners (Hewitt-Dundas and Roper, 2017), network events and awareness sessions, during which SME managers can discuss cooperation possibilities with customers, suppliers, competitors, universities and local governments, could be beneficial. Such events may encourage the development of the acquisition and assimilation dimensions of ACAP. Workshops and training programmes in which employees from all departments collectively work on an innovation case also could reiterate the power of employee collaboration for innovation, resulting in more organization-wide involvement in innovation efforts that encourage growth in all dimensions of ACAP.

Our study has several limitations. First, the cross-sectional nature of the data limits our ability to verify the causal relationships. In other words, the sequencing of the effects that we find cannot be tested. It could be the case that a successful service innovation in its turn reinforces the degree to which employees are included in the service innovation process. Future longitudinal data could provide conclusive evidence for the temporal sequencing of these effects. Second, caution is warranted regarding the generalizability of the results of this study. The model is analysed based on a sample of Dutch servitizing manufacturing SMEs, which is a very specific cultural context. Furthermore, although selection bias is not an issue, the fact that only servitizing manufacturing SMEs are part of the analysis limits the representativeness of our sample. Third, our data do not allow us 
to distinguish among different types of service innovations. Services are heterogeneous and can manifest in very different offerings (Ulaga and Reinartz, 2011). Therefore, it is possible that drivers of service innovation performance are not identical across different types of service innovation, a point that warrants further investigation. For example, researchers could use Berry et al.'s (2006) typology to investigate the effects of ACAP on different types of service innovations. In addition, further research could investigate whether ACAP develops differently in manufacturing SMEs that choose to servitize and strive for service innovation performance, compared with SMEs that do not choose this route. Finally, achieving service innovation performance requires a changed mind-set throughout the organization (Benedettini et al., 2015). Our research suggests that SMEs should ensure the collaboration of their employees in the service innovation process, but additional studies could investigate how manufacturing SMEs can establish the effective adoption of such a mind-set. Investments in employee motivation, training and other capability developments should be encouraged (Kanninen et al., 2017). An interesting research avenue would be to investigate how managers can stimulate employee collaboration, such as through support for innovation, which eventually should lead to service innovation performance and successful servitization efforts. 



\section{Chapter 4}

Identifying customer requirements for SMEs' servitized offerings A dyadic study 


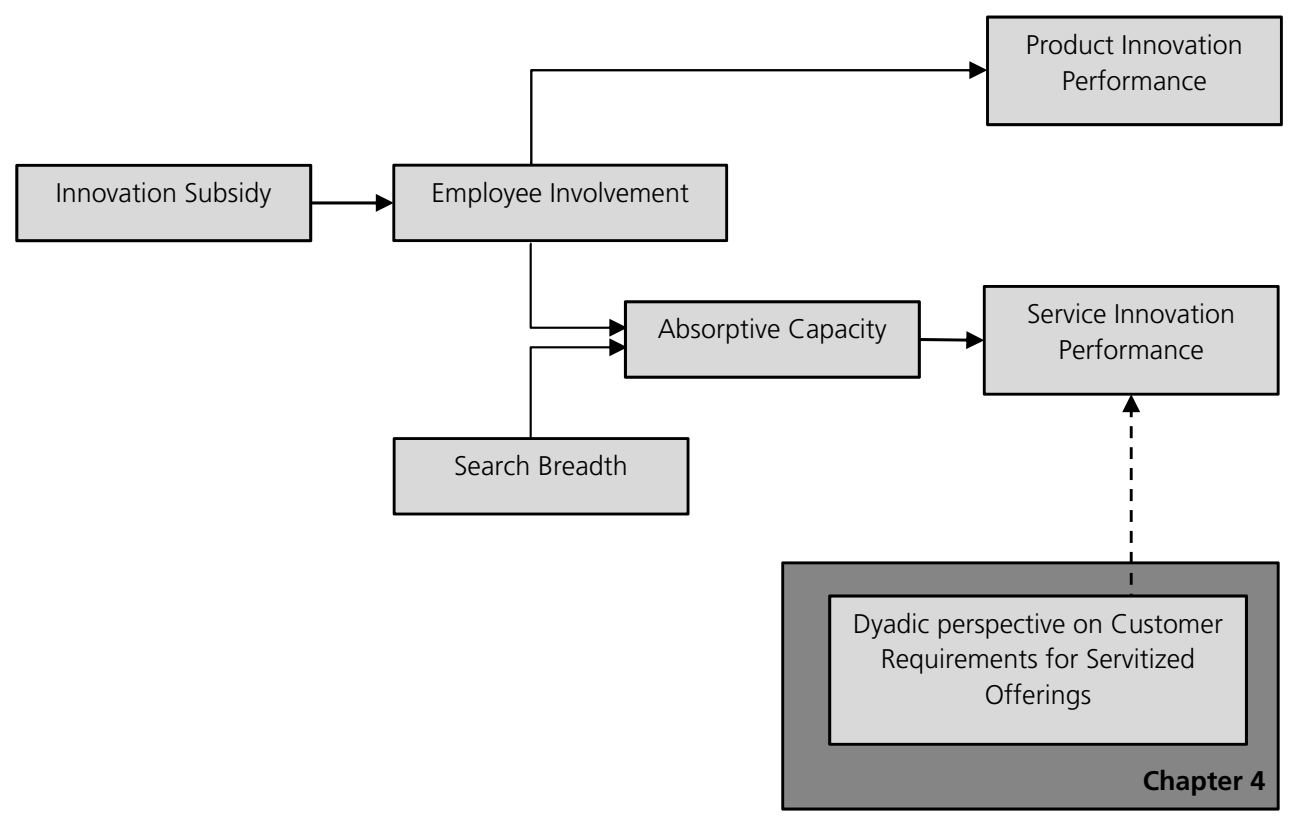

Figure 4.1. Dissertation research model - Focus of chapter 4 


\section{Introduction}

In the previous chapter, we adopted the perspective of manufacturing SMEs and investigated how they can achieve a competitive advantage based on service innovation. Achieving such a competitive advantage is one of the major reasons manufacturing SMEs pursue servitization strategies (Gebauer et al., 2005). Another important motivation for servitization is that services can increase customer loyalty and improve the response to and satisfaction of customer needs (Baines et al., 2017; Gaiardelli et al., 2014; Ostrom et al., 2010). However, many SMEs are unsuccessful in their servitization efforts (Ambroise et al., 2018), whether because they provide a servitized offering that is not what customers need or because the offer fails to create sufficient value (Valtakosi, 2017). In this chapter, we employ a dyadic research design to investigate the requirements for servitized offerings from a customer perspective, focusing on the offerings rather than the process through which the offerings are developed.

Anticipating customer needs is comparable to Tuli et al.'s (2007) notion of defining customer requirements (Saul and Gebauer, 2018). Customers increasingly demand services that can help them make the right decisions, get the product when and where they want it, utilize their purchase to its full potential, and help them cope when things go wrong (Baines et al., 2009; Olivia and Kallenberg, 2003; Vandermerwe and Rada, 1988). Moreover, customers want to focus on their own core competencies and outsource peripheral service activities (Fliess and Lexutt, 2017; Gebauer et al., 2007), in an effort to improve their production processes, so they demand increasingly sophisticated and customized services (Baines et al., 2009). Responding to these customer needs drives the servitization performance of manufacturing SMEs and requires these firms to be customer-centric (Shah et al., 2006; Storey et al., 2016).

The service-dominant logic (SDL) acknowledges the importance of such customer centricity, noting that the value of a service is perceived and determined by the customer based on "value in use" (Vargo and Lusch, 2004). We adopt an SDL perspective, which fits our servitization context, and avoid perspectives rooted in transactional or productoriented thinking (Michel, Brown and Gallan, 2008; Ordanini and Parasuraman, 2011). To be both effective and efficient at employing servitization strategies, manufacturing companies must understand how customers value their offerings (Baines et al., 2009; Vandermerwe, 2000), which can be achieved by developing servitized offerings in active collaboration with the customer (Green et al., 2017; Jaakkola and Hakanen, 2013), or what we refer to as co-creation of offerings (Oertzen et al., 2018). Customers consider cocreation with the manufacturer crucial to define their own requirements; manufacturers often underemphasize the importance of co-creation in this step of the process (Hakanen and Jaakkola, 2012; Tuli et al., 2007). Suppliers' inattention to relational aspects of cocreation also can result in lost sales opportunities, dissatisfied customers, and lower profitability (Tuli et al., 2007). 
Most studies evaluate servitization by large organizations, and these results cannot be extended blindly to an SME context (Ambroise et al., 2018; Kowalkowski et al., 2013; Valtakosi and Witell, 2018). Rather, SMEs must apply different tactics to benefit from servitization, because they may not possess the resources needed to cover investments in service businesses (Clegg et al., 2017; Gebauer, Paiola and Edvardsson, 2012). For example, SMEs often lack resources and capabilities to analyse customer service requirements (Hsieh and Chou, 2018). Because it is unclear to what extent SMEs engage in co-creation with customers when defining the requirements for servitized offerings, Research Question 3A asks:

To what extent do SMEs engage in co-creation when anticipating customer needs?

Servitizing manufacturers' tendency to underemphasize the importance of co-creation when defining the customer requirements of servitized offerings also seems to extend to research (Tuli et al., 2007). Studies of servitized offerings rarely take a customer perspective (Fliess and Lexutt, 2017; Valtakosi, 2017). Antioco et al. (2008) recommend that researchers investigate how customers perceive servitized offerings to find ways to improve the offerings or delivery process. In a study of the key success factors for delivering servitized offerings, Ulaga and Reinartz (2011) also state that it would be helpful to verify the servitizing manufacturing companies' perceptions of their customers' requirements by using actual customer insights. In short, there is a clear need to understand how customers derive value from service offerings, rather than having the value defined by the manufacturers (Neely, 2008; Vargo and Lusch, 2004). We aim to address this lack of attention with Research Question 3B:

What requirements for servitized offerings do customers have?

We use qualitative data collected from 33 in-depth interviews across 24 manufacturing SME-customer(s) dyads to investigate customers' requirements for servitized offerings and how servitizing manufacturing SMEs involve customers to anticipate those requirements. Specifically, we interviewed 9 manufacturing SME owner/managers and 2-3 customers of each SME, resulting in 24 unique dyads. We identify differences in the extent to which SMEs engage in co-creation: Some directly co-create with customers, but others do not. Moreover, we uncover key customer requirements related to reliability, customer-supplier relationships, pricing, responsiveness, tangible feedback and training, sustainable impacts on the customer organization, end-customer focus, and alignment with the internal organization.

With these findings, this chapter makes several contributions. First, we extend SME literature by addressing one of the key challenges that manufacturing SMEs face in the transition from products to servitized offerings (Paiola et al., 2013), namely, 
the anticipation of customer requirements, given SMEs' limited resources and capabilities (Hsieh and Chou, 2018). Second, we add to servitization literature by providing a taxonomy of customer requirements for servitized offerings, depending on the chosen strategy. We apply Ambroise et al.'s (2018) classification of SME servitization strategies - added services, activities reconfiguration, and business model reconfiguration - to account for this heterogeneity and confirm the need to move beyond traditional categorizations based on technical characteristics. Therefore, this taxonomy offers important insights regarding how to servitize successfully. Third, we provide a methodological contribution, by revealing the merits of dyadic servitization research, in line with recent calls for studies that shed light on how servitization affects customers and other stakeholders (Fliess and Lexutt, 2017). The dyadic set-up of our study enables us to go beyond the SME's exclusive perception of customer requirements and establish actual customer insights.

\section{Theoretical framework}

\section{Servitization strategies and SMEs}

The motives underlying servitization strategies can be strategic, financial, or marketing (Gebauer, Fleisch and Friedli, 2005; Gebauer, Gustafsson and Witell, 2011). Servitization features a high degree of heterogeneity among organizations (Ambroise et al., 2018), prompting different classifications of servitization strategies in extant literature. In these classifications, service strategies range from offering basic services, such as maintenance and support, to fully integrated combinations of products and services (Gebauer, 2008; Mathieu, 2001; Ulaga and Reinartz, 2011). We accordingly distinguish different SME servitization strategies; whereas most classifications reflect the technical characteristics of the offering (Kohtamäki et al., 2013), Ambroise et al. (2018) suggest going further, to identify strategies according to their impacts on the customer activity chain or the SME and customer business model.

We use Ambroise et al.'s (2018) classification, which features three types of strategies: added services, activities reconfiguration, and business model reconfiguration. When SMEs add services, they remain product providers and integrate service proposals, such as delivery or documentation services. This strategy does not affect the customer organization or the activity chain; its goal is to increase the focal product's value by including additional services. An activities reconfiguration strategy instead includes services that modify the customer's activity chain. The manufacturing SME performs new activities or assumes responsibility for specific customer processes, leading to a reconfiguration of responsibilities relative to traditional business models, such as when it provides software that can monitor the customer's production processes in real time. Finally, SMEs that pursue business model reconfiguration completely change their own and their customer's business models. The resulting offerings often do not transfer ownership of the product to the customer, such as outsourcing the entire process required to bathe patients in healthcare institutions. 
All three categories of servitization demand some co-creation between manufacturing companies and customers though (Ambroise et al., 2018; Gebauer et al., 2010; Valtakoski, 2017), because the collection, treatment, and analysis of customers' requirements is essential to developing adequate offerings (Kohtamäki and Partanen, 2016). Co-creation with customers represents the greatest difference between a product-oriented view and the SDL and therefore is a crucial consequence of servitization (Fliess and Lexutt, 2017; Martin and Horne, 1992; Raddats et al., 2015). Customers emphasize the importance of co-creation for defining their requirements, customization, integrating and deploying servitized offerings, and postdeployment customer support (Tuli et al., 2007). The value perceived by the customer is not always the same as that anticipated by the manufacturer (Matthyssens and Vandenbempt, 2008; Zhang and Banerji, 2017). As the SDL asserts, customer responsiveness and frequent customer interactions are key to successful service development (Fliess and Lexutt, 2017; Gebauer et al., 2005; Lusch and Vargo, 2006). Customer co-creation includes the active collaboration with customers in different stages (Oertzen et al., 2018), such that some stages (e.g., problem identification) require higher levels of co-creation. At this point, the exchange of knowledge and diagnosis of requirements are decisive (Ambroise et al., 2018). In summary, the pursuit of servitization strategies warrants continuous co-creation between the SME and the customer, to enable the SME to anticipate its customers' requirements (Ambroise et al., 2018; Kohtamäki and Partanen, 2016).

However, anticipating customer requirements remains a challenge, especially for SMEs that lack sufficient resources and capabilities to analyse service requirements in particular (Hsieh and Chou, 2018). If SMEs do not possess the necessary resources to engage in the service business (Gebauer, Paiola and Edvardsson, 2010; 2012), can servitizing SMEs engage in co-creation and anticipate their customer's requirements? This study attempts to gain insights to the extent to which SMEs actually engage in such co-creation.

\section{Customer priorities for service offerings}

Few studies take the customer's perspective on the servitized offerings of manufacturing firms (Baines et al., 2009; Sjödin et al., 2016). A servitization endeavour needs to align with customer requirements to have a chance of success (Fliess and Lexutt, 2017); customer demand for the servitized offerings is a crucial precondition of success (Kowalkowski et al., 2011). Tuli et al. (2007) assert that customers are not always aware of their own business needs, so providers must ask the right questions during the discovery process. They also find that servitizing SMEs should seek to understand customers' broad future needs, provide support in terms of spare parts and maintenance, and further develop the offering.

\section{Methodology}

To gather novel insights, we employed a dyadic, qualitative research approach, which offers an effective way to gain new knowledge about a phenomenon (Eisenhardt, 1989; 
Yin, 2009). We conducted initial in-depth interviews with servitizing manufacturing SME owner/managers to get a sense of their servitized offering and how they involved customers in its development. Through in-depth interviews with (potential) customers, we also sought to determine the customers' requirements for servitized offerings. The interview guides of these semi-structured interviews can be found in the appendix. The unit of analysis is the SME-customer dyad. The dyadic data thus provide insights into the following questions: To what extent do manufacturing SMEs engage in co-creation with their customers when anticipating customer requirements to design new servitized offerings? What requirements do the customers express? In line with Kowalkowski et al. (2013), we use an abductive approach and go back and forth between theoretical insights and empirical observations (Dubois and Gibbert, 2010). Abduction occupies the middle ground between induction and deduction, allowing for the acceptance of existing theory but also enabling data-driven theory generation (Järvensivu and Törnroos, 2010). We rely mostly on induction in the early phase, then deduction in later phases (Kowalkowski et al., 2013). Thus initially, we let the data guide the analysis, and then subsequently, we increasingly turn to existing theory.

\section{Sampling/case selection}

We selected dyads on the basis of theoretical sampling and access (Taskanen and Aminoff, 2015). Manufacturing SMEs that participated in the LimburgMakers subsidy program were contacted to determine if they were servitizing their offerings, such that the role of services was gaining importance in their business models. If so, they were qualified as eligible participants. With telephone conversations, we checked whether servitization was a relevant topic and whether each SME was planning to servitize its offerings in the near future. To spark the interest of the SME owner/managers, we promised a detailed report of the study findings, tailored to their specific situation. Of the 13 servitizing SMEs that were eligible candidates, 11 indicated they would like to take part in the study and receive the customized report, for a participation rate of almost $85 \%$. The researcher responsible for collecting the data planned face-to-face interviews with the participating SMEs, during which we verified whether managers were willing to participate, because we required the cooperation of the SME owner/manager but also needed them to refer some of their customers to us. Specifically, we asked these interviewees for the contact details of two or three potential customers of the servitized offering. At this point, 2 of the 11 initial SMEs had to quit, because they could not obtain permission to forward customer contact details. From the 9 remaining SMEs and their customers, we gathered 24 interviews. In the customer interviews, the researcher provided an adequate summary of the (planned) servitized offering and asked the customers about their requirements. The researcher contacted the customers via telephone and explained the ultimate purpose of the study, namely, to investigate how servitizing manufacturing SMEs can align their offerings with customers' requirements. Notably, $89 \%$ of the contacted customers agreed to participate, suggesting the strong willingness to co-create the development process 
for servitized offerings. The in-depth interviews were scheduled to take place either face-to-face at the customers' offices or via Skype. Table 4.1 summarizes the servitizing manufacturing SMEs, their offerings, and the customer companies that participated, with all names disguised to ensure confidentiality.

\section{Data collection}

To identify both customer requirements for servitized offerings and how servitizing SMEs co-create with customers, we designed two separate, semi-structured interview protocols. The semi-structured interview protocol and use of an independent researcher make it possible to repeat the study with similar results (Kowalkowski et al., 2013; Yin, 2003). The interview protocol for the SMEs was as follows: First, we obtained general information about the interviewee (position in the firm, job history) and the organization (firm age, amount of employees, brief history, general activities and offerings). Second, the interviewer asked about the current extent of servitization and servitized offerings. Throughout the interviews, servitization was defined as an organizational strategy in which services play an increasingly important role and contribute to firm revenues. Third, the interviewee provided in-depth insight into the new (planned) servitized offering. Fourth, potential customer contact details were requested. The semi-structured interview protocol for the customers was slightly different, but we still started with general information about the interviewee and organization, followed by questions about the current extent of servitized offerings they received in general. The interviewer then provided a thorough overview of the planned servitized offering from the servitizing SME and asked customers to reflect on this offering, in terms of their requirements and priorities.

The interviews were conducted between February and May 2017 in the Netherlands. The interviews with the SMEs lasted 1 hour and 47 minutes on average; the customer interviews lasted 1 hour and 2 minutes on average. Most interviews were conducted face-to-face, but 3 interviews with informants located far away took place via Skype.

\section{Data analysis and interpretation}

All interviewees allowed their interviews to be recorded, after which they were transcribed verbatim, resulting in 660 pages of written text. The corresponding author performed the data collection, and the entire research team, along with one external coder, participated in the data analysis, to guarantee complementary insights and increase the reliability of the findings (Eisenhardt, 1989).

First, the transcripts of the SME interviews were scrutinized by the corresponding author. All relevant information related to co-creation with customers in the process of anticipating customer requirements was gathered, summarized and interpreted for each SME. The external coder then confirmed whether the summaries were accurate and whether the interpretations were correct. The inter-rater reliability was 0.84 , well above the conventional cut-off point (Cohen and Cohen, 1983). The summaries were 
discussed among the author team, to highlight patterns, similarities, and differences across SMEs, as well as find possible links to existing theory. If necessary, the research team revisited the original data to obtain greater detail about each case, which allowed for a more in-depth understanding. These discussions then produced the framework for SME co-creation in anticipation of customer requirements for servitized offerings and its underlying motivations.

Second, with analyses of the customer interviews, we sought to identify customer requirements for servitized offerings. This analysis is similar to the approach for analysing the customer interviews, except that the insights and findings reflect three additional criteria, similar to Tuli et al. (2007):

1. Is the idea or insight applicable beyond a specific context? Answers that were very specifically related to a certain offering were not taken into account.

2. Did multiple participants mention the idea (Bendapudi and Leone, 2002)? Requirements that were mentioned by only one interviewee were excluded from our results. ${ }^{3}$

3. Does the idea go beyond the "obvious" and provide interesting and useful conclusions (Kohli and Jaworski, 1990)? We decided not to discuss obvious points, such as that the servitized offering has to add value to the customer's organization.

Ultimately, this approach enabled the author team to construct a taxonomy of customer requirements for servitized offerings. Subsequently, one of the authors, who was native Dutch and fluent in English, translated the findings from Dutch into English. The quality of the translation was evaluated by the remaining members of the research team.

\section{Results}

Among our sample of 9 servitizing manufacturing SMEs, 2 follow an added services strategy, 5 SMEs pursue an activities reconfiguration strategy, and 2 conduct a business model reconfiguration strategy.

\section{Co-creation in anticipation of customer requirements for servitized offerings}

In this section, we examine and interpret the results of the interviews to answer Research Question 3A: To what extent do SMEs engage in co-creation when anticipating customer needs? As Table 4.2 shows, the sample contains an approximately equal distribution of

\footnotetext{
${ }^{3}$ For example, when interviewing a customer of Caretaker Ltd. about the service-level agreement, he indicated the company wanted to obtain certain add-ons of the product for free. These add-ons were very specific to the offering provided by Caretaker Ltd. to this customer, so we did not incorporate it into our discussion.
} 
Table 4.1. Overview of SMEs and customers participating in the study

\begin{tabular}{|c|c|c|c|}
\hline Firm & Founding year & Employees & Service offering \\
\hline Conveyor Ltd. & 1994 & 98 & $\begin{array}{l}\text { Digital service platform/app that optimizes } \\
\text { repair services. All machines with conveyor belts } \\
\text { have a QR-code linked to the app, providing all } \\
\text { necessary information about the conveyor belt }\end{array}$ \\
\hline Stockingsupport Ltd. & 1994 & 165 & $\begin{array}{l}\text { Performing bathing process for healthcare } \\
\text { patients }\end{array}$ \\
\hline Workbench Ltd. & 2008 & 24 & $\begin{array}{l}\text { Software providing real-time insight into } \\
\text { the customer's production processes }\end{array}$ \\
\hline Moonraker Ltd. & 1991 & 15 & $\begin{array}{l}\text { High-tech engineering services on a project } \\
\text { basis }\end{array}$ \\
\hline Flowchart Ltd. & 1979 & 20 & $\begin{array}{l}\text { Software providing real-time insight into } \\
\text { the customer's processes }\end{array}$ \\
\hline Digester Ltd. & 1952 & 23 & $\begin{array}{l}\text { Providing customers with a suitcase with spares } \\
\text { for parts that break down most often }\end{array}$ \\
\hline Shepherd Ltd. & 1982 & 25 & $\begin{array}{l}\text { Providing a central platform that offers real-time } \\
\text { overviews of conditions in cattle sheds }\end{array}$ \\
\hline Merchant Ltd. & 2016 & 6 & $\begin{array}{l}\text { Filling in idle machine capacity via an online } \\
\text { platform }\end{array}$ \\
\hline Caretaker Ltd. & 2013 & 12 & $\begin{array}{l}\text { Providing maintenance and repair services via } \\
\text { a service-level agreement }\end{array}$ \\
\hline
\end{tabular}




\begin{tabular}{|c|c|c|c|}
\hline Servitization strategy & Current product offering & Customer ID & Type of customers interviewed \\
\hline \multirow[t]{3}{*}{ Added services } & \multirow{3}{*}{$\begin{array}{l}\text { Conveyor belts transport } \\
\text { line machinery }\end{array}$} & $A$ & Recycling company \\
\hline & & B & Aluminium sand foundry \\
\hline & & C & $\begin{array}{l}\text { Producer of fertilizer for } \\
\text { mushroom cultivation }\end{array}$ \\
\hline \multirow{3}{*}{$\begin{array}{l}\text { Business model } \\
\text { reconfiguration }\end{array}$} & \multirow[t]{3}{*}{ Diverse healthcare products } & $\mathrm{D}$ & Large hospital \\
\hline & & $E$ & Large healthcare institution \\
\hline & & $\mathrm{F}$ & Large healthcare institution \\
\hline \multirow[t]{3}{*}{ Activities reconfiguration } & \multirow[t]{3}{*}{ Automated (robot) solutions } & G & $\begin{array}{l}\text { Mechanical precision } \\
\text { parts supplier }\end{array}$ \\
\hline & & $\mathrm{H}$ & $\begin{array}{l}\text { Mechanical precision } \\
\text { parts supplier }\end{array}$ \\
\hline & & । & $\begin{array}{l}\text { Mechanical precision } \\
\text { parts supplier }\end{array}$ \\
\hline \multirow[t]{3}{*}{ Activities reconfiguration } & \multirow[t]{3}{*}{ Cryogenic products } & J & $\begin{array}{l}\text { High-tech company in } \\
\text { semiconductor industry }\end{array}$ \\
\hline & & K & $\begin{array}{l}\text { High-tech company in } \\
\text { semiconductor industry }\end{array}$ \\
\hline & & L & $\begin{array}{l}\text { Producer of machines for solar } \\
\text { cell production }\end{array}$ \\
\hline \multirow[t]{3}{*}{ Activities reconfiguration } & \multirow{3}{*}{$\begin{array}{l}\text { Products for preservations } \\
\text { of agricultural products in } \\
\text { sheds, such as air washers }\end{array}$} & M & $\begin{array}{l}\text { Ventilation technique installer } \\
\text { for agro food industry }\end{array}$ \\
\hline & & $\mathrm{N}$ & Pig farm \\
\hline & & 0 & Agricultural farm \\
\hline \multirow[t]{2}{*}{ Activities reconfiguration } & \multirow{2}{*}{$\begin{array}{l}\text { Machines for processing } \\
\text { agricultural products, such } \\
\text { as carrots }\end{array}$} & $P$ & French fries producer \\
\hline & & Q & French fries producer \\
\hline \multirow[t]{2}{*}{ Activities reconfiguration } & \multirow{2}{*}{$\begin{array}{l}\text { Climate control systems for } \\
\text { cattle sheds }\end{array}$} & $\mathrm{R}$ & Poultry farm \\
\hline & & $\mathrm{S}$ & Pig farm \\
\hline \multirow[t]{2}{*}{$\begin{array}{l}\text { Business model } \\
\text { reconfiguration }\end{array}$} & \multirow[t]{2}{*}{ 3D-printing products } & $\mathrm{T}$ & $\begin{array}{l}\text { Mechanical precision } \\
\text { parts supplier }\end{array}$ \\
\hline & & U & $\begin{array}{l}\text { Mechanical precision parts } \\
\text { supplier for medical sector and } \\
\text { airline industry }\end{array}$ \\
\hline \multirow[t]{3}{*}{ Added services } & \multirow[t]{3}{*}{ Diverse healthcare products } & V & Community care centre \\
\hline & & W & $\begin{array}{l}\text { Regional healthcare } \\
\text { institution for people suffering } \\
\text { from dementia }\end{array}$ \\
\hline & & $x$ & Regional healthcare institution \\
\hline
\end{tabular}


Table 4.2. SME co-creation with customers when anticipating customer requirements for servitized offerings and underlying motivations

\begin{tabular}{lll}
\hline & No customer co-creation & Customer co-creation \\
\hline SMEs & Conveyor Ltd. & Caretaker Ltd. \\
& Shepherd Ltd. & Workbench Ltd. \\
& Digester Ltd. & Stockingsupport Ltd. \\
& Flowchart Ltd. & Merchant Ltd. \\
& Moonraker Ltd. & \\
\hline Underlying & - Knowledge is internally available & - Co-creation is initiated by the customer \\
motivations & $-\quad$ Lack of resources to co-create & SME sees the added value \\
& - Co-creation is not in SME's nature & of co-creation \\
\hline
\end{tabular}

SMEs that co-create with their customers and those that do not. With one exception, older SMEs - founded before 2000 - do not co-create with customers.

\section{No co-creation}

Despite evidence that co-creation with customers is important for identifying customer requirements for a new service (Ambroise et al., 2018), some SMEs do not involve their customers directly, for three main reasons. First, some of the interviewees believe that their SME has the necessary knowledge available internally, as illustrated by the following quote:

Actually, we got the idea already quite a while ago already. Our engineers had just been playing with the latest techniques, because that is what they like to do. It's just that the market is going in that direction. If we don't provide our customer's data via software online, accessible via mobile devices, someone else will. So we base our decision to develop this software more or less on gut feeling. Our feeling about what we should be doing. (Flowchart Ltd.)

For example, Workbench Ltd. was developing software to monitor customers' internal processes, which they already were doing. As a result, it could anticipate its customers' requirements:

As an entrepreneur I see a lot of opportunities because I am doing the same thing as my customers. Therefore, it is easy for me to recognize opportunities. As a result we started to develop the software that allows our customers to monitor their machines real-time. 
Second, some managers knew they should co-create with customers in the development process, but collaboration with the customer was not in the company's DNA:

We always say we should include customers in our development process, but we do not actually do it. I think it is just more in our nature to have an internal focus instead of collaborating with customers. I think that collaboration with our customers would ultimately create the most value added for both us and the customer. (Shepherd Ltd.)

Third, some simply lacked the time and resources to co-create with customers:

We have a lot of different responsibilities, such as marketing, production, sales and maintenance that receive priority over the development of new services and consulting customers in the process. We now almost have the financial options to hire someone dedicated to that. (Digester Ltd.)

\section{Co-creation}

Other SMEs had direct contact with their customers in their effort to anticipate customer requirements for new services. With one exception, they are younger SMEs, founded after the year 2000. In some cases, new services resulted directly from customers initiating the co-creation, such as for Caretaker Ltd.:

Our new services are developed primarily as a result of customers directly expressing their needs. The ball often starts rolling when we are doing something else for a customer, we talk to their management and employees and they express their needs.... Then we start a conversation: What could be an interesting solution for you? ... After a while, we get more of a feeling for what need we are actually attempting to satisfy.

Some SME managers noted the importance of co-creating with customers when defining customer requirements, so they deliberately sought interactions with customers:

We deliberately put our employees in the "user-situation" together with customers, in order to make sure they receive first-hand information. We need to have intense contact with our target market and not have many parties in between. (Stockingsupport Ltd.) 
Months, or maybe even years, before we started developing the software, I went to existing customers to talk about the idea, whether it is possible. Then you taste the need. (Workbench Ltd.)

We call potential customers, visit them, talk to them and adapt our value proposition based on what our customers tell us.... Even if you have the greatest idea, if you take it to the market $60 \%$ does not like it, says they do not have the need or are doing it themselves. I know that even this $60 \%$ ultimately has a need, but maybe we are too small or the timing is not right, or we first have to offer something else. And you only know that if you actually talk to your customers. (Merchant Ltd.)

\section{Customer requirements for service offerings}

We next turn to Research Question 3B: What requirements for servitized offerings do customers have? Some of the customer requirements that we identify align with the service quality (SERVQUAL) dimensions identified by Parasuraman et al. (1985). The SERVQUAL concept is closely related to customer requirements for servitized offerings, because customers derive value from a service depending on its ability to fulfill their requirements (Vargo and Lusch, 2004). The SERVQUAL instrument evaluates service quality on five dimensions: tangibles, reliability, responsiveness, assurance, and empathy. The tangibles, reliability, and responsiveness dimensions also surfaced in our analysis. Tangibles refer to the appearance of physical facilities, equipment, personnel, and written materials; reliability refers to an ability to perform the promised service dependably and accurately; and responsiveness is the degree to which the service provider is willing to help customers and provide prompt service. We also find that the needs for assurance, provided by courteous employees who convey trust and confidence, and empathy, manifested as caring, individualized attention from the firm to customers, converge in our analysis. Therefore, we merge the assurance and empathy dimensions of SERVQUAL into a customer-supplier relationship dimension. Furthermore, we identify five novel customer requirements for servitized offerings: pricing, feedback and training, sustainable impact on the customer organization, end-customer focus, and alignment with the customer's internal organization. We elaborate on these different categories and the specific service aspects they contain next, followed by a synthesis of the findings.

\section{Reliability}

According to Parasuraman et al. (1985), reliability relates to the ability to perform the promised service dependably and accurately. The customer interviews clearly revealed it as a relevant dimension for all three servitization strategies. Customers want service providers with a high level of expertise, so they can rely on them to perform the service 
and comfortably outsource the related activities fully, without having to invest time or resources in it, as the following quote exemplifies:

I do not need to know what is wrong. They should be the experts and figure out how to solve the issue! I just want to come to the factory next day and see that they have solved the problem. (Customer B - Conveyor Ltd.)

\section{Responsiveness}

Many interviewees mentioned responsiveness as important, in line with Parasuraman et al.'s (1985) findings, for both the added services and activities reconfiguration strategies. It reflects the extent to which the service provider is willing to help customers and provide prompt service (Parasuraman et al., 1985). Customers expect to receive quick and, in some cases, 24/7 service from service providers in their geographic proximity. For example,

If we have a standstill we need them to fix it within a few hours, because a standstill costs us $€ 160$ per minute, so our installation has to run.

(Customer A - Conveyor Ltd.)

If we would sign a service-level agreement and one of the devices breaks down, I would minimally expect a maintenance technician on my doorstep the next day. (Customer W - Caretaker Ltd.)

I need to be able to reach them in the middle of the night, and want them to jump in their car right away, if necessary. (Customer P-Digester Ltd.)

\section{Tangibles}

Tangibles reflect the appearance of physical facilities, equipment, personnel, websites, mobile phone apps, and communication materials. They form physical and virtual representations or images of the provided service (Wilson et al., 2016). For this category, customers mentioned aspects such as the design of an application or software, its continuous development and ease of use, and customization options. According to these customers, tangible aspects of a service are important for organizations that pursue the added services and activities reconfiguration strategies.

I think the design of the web application should be attractive. This could be done for instance by using graphical representation instead of just plain text. I would like that. (Customer O - Flowchart Ltd.) 
I want to be able to customize the design of the software they provide. They need to provide me with an offering that contains just that what I want, not too little, not too much. (Customer $\mathrm{H}$ - Workbench Ltd.)

\title{
Customer-supplier relationship
}

Tuli et al. (2007) argue that customers have a relational process view of servitized offerings. Similarly, our interviews reveal that the customer-supplier relationship is a customer priority for all servitization strategies. On the one hand, a preexisting relationship can be a main reason to choose a service provider; on the other hand, long-term future collaboration perspectives may convince customers:

\begin{abstract}
We have been happy with their devices for a long time. We are never obliged to stick with them, but it is of course very convenient if you stay with the same supplier if you expand. It is easy because you can connect devices from the same supplier to one another. (Customer $\mathrm{N}$-Flowchart Ltd.)
\end{abstract}

I want a service provider with a solid organization and long future perspective, because that allows me to build a long-term relationship.

(Customer R - Shepherd Ltd.)

Some customers also expressed that long-term collaborations require an SME to earn no more than some limited percentage of its total revenue from their specific collaboration, because that limitation ensures that the service provider is not totally dependent on the customer and has stable future options. Other important aspects related to the customer-supplier relationship include clear agreements, open communication, active listening to customer requirements, mutual trust, and an ability to empathize and understand the customer's business.

\section{Pricing}

Pricing refers to aspects of the offering related to costs and payments. Pricing decisions have significant influences on revenue streams and profitability (Zeithaml et al., 1985), and inadequate pricing causes many companies to be unable to servitize successfully (Gebauer et al., 2005). For the added services and activities reconfiguration strategies, customers emphasized a fair price as important and also demanded a clear business case, upfront. Some customers noted that they would expect future discounts in return for their loyalty, and others stipulated that they wanted services performed on a fixed price basis instead of hourly invoices. For SMEs following a business model reconfiguration strategy, customers note that the way the price is calculated also matters. Specifically, they sought 
organizations that would agree on the price upfront, instead of issuing hourly invoices afterward. The following quotes illustrate such reactions:

I would really need to see a clear and honest business case before I sign a servicelevel agreement. How high are the call-out costs? What would a reparation cost without the agreement, so what is the advantage if I buy off this risk?

(Customer X-Caretaker Ltd.)

We have a lot of suppliers offering services that are billed via hourly invoice. I am looking for suppliers who go beyond that. For instance, if a project and its scope are clearly delineated, a service provider should be able to devise a good plan and make a suitable tender offer. (Customer J - Moonraker Ltd.)

\section{Feedback and training}

Customers of SMEs that pursue added services and activities reconfiguration strategies indicate they value service providers that go beyond simple service provision. From their point of view, servitized offerings inherently involve interactions and co-creation (Hakanen and Jaakkola, 2012). Customers want these service providers to think along with them, demonstrate critical thinking, and then proactively provide feedback, suggestions for improvement, training, or workshops for using the offering. As following quotes illustrate, service providers must demonstrate critical thinking and provide added-value training:

To us, it is important that service providers do not just go along with everything we say. I want a service provider who tells me: Yes, we understand your problem and the solution you propose, but given our competences we offer a better alternative.

(Customer K-Moonraker Ltd.)

It would be great if they could do a little workshop for our employees on how to use the product once they are here for maintenance. It would be a good memory freshener about all different functionalities and applications for our employees.

(Customer V -Caretaker Ltd.)

\section{Sustainable impact on customer organization}

Contrary to the added services and activities reconfiguration strategies, customers of SMEs pursuing business model reconfiguration strategies tended to emphasize the bigger picture, including long-term effects on their business management instead of focusing on pricing for example. This demand entails organizational sustainability, a topic that is highly relevant for SMEs (Darcy et al., 2014). Interviewees stated that a service offering 
should be efficient and sustainable, with positive effects on business management and the sustainability of the customer's organization.

Such service offerings should be sustainable and have a positive effect on our business management. In this case, outsourcing the bathing process could potentially solve the problem we have with a shortage of nurses on the labor market. (Customer D -Stockingsupport Ltd.)

The offering should be sustainable in the long run. Not just for the environment, but also for us as a company. (Customer $U$-Merchant Ltd.)

\section{End-customer focus}

Organizations that follow a business model reconfiguration strategy completely overhaul their own and their customers' business models and get involved in customers' activity chains (Ambroise et al., 2018). Vandermerwe and Rada (1988) note that through servitization, firms move down the distribution chain and grant increasing attention to end consumers. As our study shows, providing servitized offerings often involves interactions with the customer's customer, or end-customers. It became apparent from the interviews that customers want the service providers to create value for their end-customers and take their requirements into consideration too, as follows:

Our service providers should put value creation for the end customer central. They should not try to think of something that improves anything for us - the customer in between - but really focus on serving the needs of the end customer. If they do that, then together we could make huge steps. (Customer -Merchant Ltd.)

I would need a service provider with employees that have the appropriate attitude and mindset toward my patients. (Customer E -Stockingsupport Ltd.)

\subsubsection{Alignment with internal processes}

Finally, customers of SMEs pursuing business model reconfiguration strategies consider it important that the performed services align with their existing internal processes. Similarly, Alghisi and Saccani (2015) find that it is critical to provide servitized offerings that can be tailored to the customer organization. Then other processes or activities may be linked to the activity that is outsourced to the service provider, as the following example illustrates: 
Bathing our patients currently is an important part of our nurse's job which is intertwined with other tasks. During the bathing, nurses check whether a wound

has healed, or they test the motor skills of a patient, so we can intervene in time if necessary. At the moment we cannot separate these tasks. (Customer F Stockingsupport Ltd.)

\section{Discussion}

\section{Distinguishing SMEs by the extent to which they co-create with customers}

The first goal of this study was to explore the extent to which servitizing manufacturing SMEs co-create with their customers to anticipate their requirements for service offerings. Collecting and analysing customer's requirements is an essential part of service provision (Kohtamäki and Partanen, 2016). Some researchers even assert that co-creation is the key distinction between a product-centred and a service-centred view, such that it constitutes one of the most crucial challenges of servitization (Fliess and Lexutt, 2017; Martin and Horne, 1992; Raddats et al., 2015). Customers emphasize the importance of co-creation for defining their requirements, whereas servitizing manufacturers tend to take a transactional view (Tuli et al., 2007). Despite widespread agreement among servitization scholars that customer co-creation is a fundamental precondition for success (Fliess and Lexutt, 2017; Gebauer et al., 2005; Lusch and Vargo, 2006), only 5 of the 9 SMEs in our sample co-create to identify their customers' requirements. There are three reasons SMEs do not engage in co-creation. First, they lack the time and resources to co-create (Hsieh and Chou, 2018). Second, co-creation might not be in the SME's nature, even if management realizes it is important. Notably, with one exception, the older SMEs founded before 2000 are the organizations that do not involve their customers in the process, implying an influence of organizational inertia, such that stable processes and policies makes it difficult for existing firms to adapt to changing environments (Hannan and Freeman, 1984). Routines may become so embedded within the organization that it issues automatic responses based on its prior experiences and exhibits internal resistance to change (Nelson and Winter, 1982), even changes that would lead to necessary cocreation efforts. Third, some SMEs assert that they already possess knowledge about their market and customers. Therefore, they anticipate customer requirements within their organizational boundaries, without direct customer co-creation. In contrast, the 4 SMEs that directly involve their customers cite two main motivations. First, customers sometimes initiate co-creation by expressing their requirements. Second, some SMEs realize the importance of customer co-creation and actively involve their customers. 


\section{Customer requirements for servitized offerings by SMEs' servitization strategy}

As a second goal, we sought to identify customers' requirements for servitized offerings. Some identified customer requirements for servitized offerings are analogous to the dimensions with which Parasuraman et al. (1985) measure service quality, namely, the responsiveness and reliability of the service provider and tangible aspects, such as software design. The importance of a good customer-supplier relationship reflects Tuli et al.'s (2007) finding that customers view a solution as a set of customer-supplier relational processes. In terms of pricing, it is not just the price but also the way it gets calculated that is relevant. This aspect constitutes a major challenge though, because servitizing firms often have given their services away for free in the past, to support their product sales, and now they struggle to change their pricing and revenue models in ways that customers will accept (Reinartz and Ulaga, 2008).

Customers also emphasize the relevance of an alignment with their own internal processes. Activities, processes, and competencies all need to be aligned between the service provider and the customer for servitization to be successful (Fliess and Lexutt, 2017). Such an alignment also requires the customer to share critical information about its business processes (Tuli et al., 2007). Other key priorities include feedback and training, the offering's impact on organizational sustainability, and a focus on the endcustomer. Taking Ambroise et al.'s (2018) classification of SME servitization strategies into account provides several insights, as detailed in Table 4.3. The importance of a reliable service provider, a good customer-supplier relationship, and pricing are universal across all servitization strategies. The value of the relationship between customer and supplier also reflects findings by Tuli et al. (2007) that customers view servitized offerings as a set of relational processes.

A comparison of the customer requirements across the added services and activities reconfiguration strategies, as pursued by 2 and 5 SMEs, respectively, relative to those for the business model reconfiguration strategy, as followed by 2 SMEs, yields interesting insights. The differences in requirements across strategies suggest that when a servitized offering involves a complete overhaul of the customer's business model, distinct priorities rise to the surface. Responsiveness, tangibles, and feedback and training are important customer requirements for the added services and activities reconfiguration strategies, because they focus on the servitized offering and its proper functioning. For SMEs with a business model reconfiguration strategy, alignment with internal processes, sustainable impacts on customer organization, and a focus on the end-customer are vital, reflecting the demand that the servitized offering fits the organization and its bigger picture overall.

\section{Conclusions}

Although SMEs increasingly follow servitization strategies, many are unsuccessful in their efforts (Ambroise et al., 2018), possibly because a servitized offering is not what 
Table 4.3. Taxonomy of customer requirements for servitized offerings per servitization strategy

\begin{tabular}{llll}
\hline & Added & Activities & Business model \\
Requirements & services & reconfiguration & reconfiguration \\
strategy & strategy & strategy \\
\hline
\end{tabular}

Basic requirements across all servitization strategies

1. Reliability

2. Customer-supplier relationship

3. Pricing

$\begin{array}{lll}\checkmark & \checkmark & \checkmark \\ \checkmark & \checkmark & \checkmark \\ \checkmark & \checkmark & \checkmark\end{array}$

Requirements focused on offering and its proper functioning
4. Responsiveness
5. Tangibles
6. Feedback \& training

Requirements focused on fit with customer organization and long-term effects

7. Sustainable impact on customer organization

8. End-customer focus

9. Alignment with internal processes

the customer needs or because it fails to create sufficient value (Valtakosi, 2017). With a dyadic, qualitative study, we advance knowledge on how SMEs can provide more appealing servitized offerings to customers.

First, we highlight the extent to which servitizing SMEs engage in co-creation when defining customer requirements (Research Question 3A). Servitization scholars have shown that customer co-creation facilitates SMEs' understanding of customer requirements for their servitized offerings (Green et al., 2017; Hakanen and Jaakkola, 2012). From the current research, we can further deduce that many SMEs simply do not engage in co-creation, because they lack the resources, have internal customer knowledge, or find co-creation unnatural. Because co-creation ensures alignment between the servitized offering and customer needs (Hakanen and Jaakkola, 2012), we posit that this negligence is a key driver of unsuccessful servitization. Stimulating SMEs to co-create servitized offerings could drastically increase their success.

Second, we provide critical insights into the requirements that customers establish for servitized offerings (Research Question 3B). In total, we identify 9 customer requirements, distinct across servitization strategies, as the taxonomy in Table 4.3 details. This taxonomy, derived from actual customer data, specifies which customer requirements to take into account, depending on the SME's chosen servitization strategy. For example, the customer-supplier relationship is an important factor for all three servitization strategies, but adopting a business model reconfiguration strategy means that the servitizing manufacturing SME also needs to demonstrate the sustainable impact 
of its offering on the customer organization. Using the guidelines established by this taxonomy can facilitate successful servitization, by increasing the alignment between the servitized offering and customer needs.

These findings in turn produce several contributions to prior literature. First, we add to SME literature by addressing the largely overlooked challenges facing SMEs as they transition from products to servitized offerings (Paiola et al., 2013). One of these challenges is anticipating customer requirements, which is difficult for SMEs with their limited resources and capabilities (Hsieh and Chou, 2018). Thus SMEs in particular must adopt a customer-centric perspective to identify customer requirements for servitized offerings (Alpkan, et al., 2007; Clegg et al., 2017; Vargo and Lusch, 2004). We provide novel insights into how SMEs cope with this challenge by investigating how servitizing SMEs involve their customers in the process of developing servitized offerings. We differentiate SMEs that do and do not directly co-create with customers and outline their underlying motivations.

Second, we add a customer perspective to servitization literature. Even when it advocates customer-centricity (Clegg et al., 2017; Vargo and Lusch, 2004), existing research tends to ignore the customer perspective on servitized offerings. However, customer demand is a basic precondition for servitization (Kowalkowski et al., 2011), and not living up to customer requirements is one of the main reasons that many servitization efforts fail (Valtakosi, 2017). We develop a taxonomy that reveals customers' priorities for servitized offerings, according to the SME's servitization strategy. Some requirements appear universal across strategies, but differences also arise, depending on whether the strategy requires a change to the business model of the servitizing SME and its customer. If SMEs pursue a strategy that changes the business models of their and their customer's organization, the resulting requirements focus more on the long-term effects of the offering and its fit with the entire organization. For the other strategies, the requirements are more centred on the offering itself and its proper functioning.

Third, we offer a methodological contribution. With our dyadic study design, we answer calls for this type of research as a key means to shed further light on how servitization affects customers and other stakeholders (Fliess and Lexutt, 2017). It also goes beyond the SME's perspective, such that we can analyse actual customer requirements. By including both SME owner/managers and their customers in this study, we also derive detailed reports, with findings tailored to specific SMEs that provide owner/managers with unique customer insights, without demanding more of their limited resources (Hsieh and Chou, 2018). Moreover, we confirm that customers are willing to participate, because they saw this study as an opportunity to voice their preferences for servitized offerings.

Even as more firms adopt servitization strategies, their attempts continue to fail often (Valtakosi, 2017). With their resource limitations (Gebauer, Paiola and Edvardsson, 2012), SMEs cannot afford such failures, especially if they result from a resolvable inability to meet customer requirements (Valtakosi, 2017). Our analysis uncovers customer requirements 
for three different servitization strategies; taking these requirements into account when developing and positioning new servitized offerings should increase acceptance of the offerings by customers. For example, if they adopt a business model reconfiguration strategy, SMEs should ensure their offering aligns with the customer's internal processes and adds value for end-customers as well. This effort ultimately should result in more successful servitization outcomes.

We also note the informants' high willingness to participate in this study. The servitizing SMEs recognized the value of the research; some SME owner/managers asked repeatedly when the tailor-made report would be available. These servitizing SMEs sought guidance for how to align their servitized offerings with their customer requirements. In addition, the $89 \%$ participation rate by customers highlights their desire to express their requirements and cooperate. Our research experiences in turn indicate a vast opportunity for policy makers seeking to improve servitization efforts: They should bring servitizing SMEs and customers closer together. Starting the conversation, as we did for our research, and facilitating the interaction between SMEs and customers should enhance servitization efforts (Fliess and Lexutt, 2017; Lusch and Vargo, 2006).

Our taxonomy provides an indication of which requirements are relevant to each servitization strategy, without detailing how the servitized offerings should be configured to satisfy these requirements. What constitutes a good relationship or fast response is customer specific, and we encourage SMEs to engage in co-creation with their customers to find out how their servitized offering should be tailored to a specific customer. We find that only half of the SMEs in our sample engage in co-creation, so we also recommend that policy makers should work to create more awareness, especially among older SMEs, about the importance of co-creation. Our results indicate that proactive customer behaviours can induce SME co-creation routines; by initiating co-creation, customers can ensure that SMEs have a better understanding of their requirements (Green et al., 2017). Ultimately, this effort will result in a better alignment between the SME's customer offerings and their own requirements.

The data for this qualitative study were obtained in interviews with 9 SME owner/ managers and 2-3 customers per SME, an approach that provides in-depth insights but also has several limitations. First, we used only one key informant per SME, mainly to limit the time participants needed to invest in the study; we wanted to lower barriers to participation as much as possible. From a service provider perspective though, the interviewed owner/manager might not have a complete picture of how customer requirements and priorities are anticipated by (frontline) employees. Further research should include SMEs' employees, at multiple layers in the organization, to gather more evidence. Second, our data are cross-sectional. Customers considered a new servitized offering and indicated their requirements for it. These requirements might change after the customers actually adopt and implement the servitized offering. Longitudinal studies would be helpful in this regard. Third, our sample size is limited, and only 2 SMEs took an 
added services servitization strategy, while 2 pursued a business model reconfiguration strategy. Larger samples might reveal whether involving customers in the anticipation of their requirements differs by the chosen servitization strategy. In this study, we focused on customer requirements for servitized offerings as such. Future research could further help SMEs servitize successfully by investigating customer requirements for the process through which the offerings are developed. Finally, further research could expand the dyadic perspective to take end-customers into account, reflecting our finding that, from a direct customer point of view, the added value for the end-customer is very important. 




\section{Chapter 5}

Conclusion 

With this dissertation, I sought to provide a holistic view of how to improve the innovation performance of SMEs, by adopting perspectives of three different, relevant actors in the SME innovation process. With this final chapter, I provide a concise summary of the results of the studies (see Table 5.1), then synthesize the findings to formulate an answer to my overarching research question: What are the drivers of SME innovation performance? Finally, I offer some final thoughts and avenues for further research.

\section{Synopsis}

In Chapter 2, I take a policy maker perspective and investigate the impact of innovation subsidy programs to contribute to the debate among academics and policy makers about whether investments in innovation subsidy programs are well spent (Clarysse et al., 2009). I position my study within the field of behavioural additionality research, which focuses

Table 5.1. Summary of the studies

\begin{tabular}{|c|c|c|c|}
\hline & Chapter 2 & Chapter 3 & Chapter 4 \\
\hline Perspective & Policy maker & Intra-organizational SME & SME-customer dyad \\
\hline Method & $\begin{array}{l}\text { Combined matching and } \\
\text { difference-in-differences } \\
\text { approach }\end{array}$ & $\begin{array}{l}\text { Structural } \\
\text { equation modelling }\end{array}$ & $\begin{array}{l}\text { Qualitative } \\
\text { content analysis }\end{array}$ \\
\hline $\begin{array}{l}\text { Research } \\
\text { Question }\end{array}$ & $\begin{array}{l}\text { What is the impact of } \\
\text { receiving an innovation } \\
\text { subsidy on an SME's } \\
\text { employee involvement? }\end{array}$ & $\begin{array}{l}\text { What are the organizational } \\
\text { mechanisms allowing } \\
\text { SMEs to achieve service } \\
\text { innovation performance? }\end{array}$ & $\begin{array}{l}\text { To what extent do SMEs } \\
\text { engage in co-creation } \\
\text { when anticipating } \\
\text { customer needs, and } \\
\text { what requirements for } \\
\text { servitized offerings do } \\
\text { customers have? }\end{array}$ \\
\hline Key Finding & $\begin{array}{l}\text { Innovation subsidies result } \\
\text { in increased employee } \\
\text { involvement. In turn, this } \\
\text { involvement has a positive } \\
\text { influence on an SME's } \\
\text { innovation performance. }\end{array}$ & $\begin{array}{l}\text { Internal employee } \\
\text { collaboration and a diverse } \\
\text { set of external innovation } \\
\text { partners reinforce an SME's } \\
\text { absorptive capacity, which } \\
\text { drives service innovation } \\
\text { performance. }\end{array}$ & $\begin{array}{l}\text { About half of the SMEs } \\
\text { co-create servitized } \\
\text { offerings. Customers } \\
\text { have } 9 \text { requirements } \\
\text { for servitized offerings, } \\
\text { and their relevance } \\
\text { depends on the chosen } \\
\text { servitization strategy. }\end{array}$ \\
\hline $\begin{array}{l}\text { Key } \\
\text { Contribution }\end{array}$ & $\begin{array}{l}\text { Robust evidence that } \\
\text { subsidies structurally } \\
\text { improve organizational } \\
\text { innovation behaviour, } \\
\text { beyond the scope of } \\
\text { a specific } \\
\text { innovation project. }\end{array}$ & $\begin{array}{l}\text { A framework of how } \\
\text { manufacturing SMEs } \\
\text { can achieve service } \\
\text { innovation performance, } \\
\text { allowing more successful } \\
\text { servitization efforts. }\end{array}$ & $\begin{array}{l}\text { A taxonomy that grants } \\
\text { insights into the customer } \\
\text { requirements for } \\
\text { servitized offerings per } \\
\text { servitization strategy. }\end{array}$ \\
\hline
\end{tabular}


on changes in a firm's behavior after receiving a subsidy. The data set, consisting of longitudinal data I collected from manufacturing SMEs, reveals the effects of innovation subsidies from a unique angle and thus establishes some novel insights. Namely, I identify changes in internal collaboration behaviour after receiving a subsidy, because innovation subsidies provide SMEs with financial resources that enable SME management to involve their employees in strategic activities such as innovation. This significant finding complements existing knowledge about the positive effects of employee involvement, by revealing its influence on product innovation performance. Thus, innovation subsidies can have a more structural effect on an SME's innovation performance, beyond support for a specific innovation project, through their potential to alter organizational behaviour.

In Chapter 3, I adopt an intra-organizational SME perspective to find out which organizational mechanisms manufacturing SMEs can use to achieve a competitive advantage based on service innovations. Manufacturing SMEs acknowledge that services delivery is becoming an increasingly important part of their business model (PA Consulting Group, 2018), but they lack systematic insights into how to conduct service innovation (Baines et al., 2009). I find that both internal employee collaboration and collaboration with diverse external innovation partners can stimulate the development of absorptive capacity - that is, an ability to recognize, assimilate, and exploit valuable external knowledge (Cohen and Levinthal, 1990). When SMEs possess absorptive capacity, they can use this ability to develop service innovations that are superior to those offered by their competitors.

In Chapter 4, I leverage a dyadic SME-customer perspective to shed light on the extent to which SMEs engage in co-creation, as well as the actual customer requirements for servitized offerings. Customer co-creation facilitates the accurate identification of customers' requirements for servitized offerings (Fliess and Lexutt, 2017), but whether SMEs engage in co-creation is unknown. Insights into actual customer requirements for servitized offerings could enable SMEs to provide offerings that are more optimally tailored to customer needs. From interviews with both SMEs and their respective customers, I deduce that many SMEs do not engage in co-creation, for three reasons: because they believe the knowledge is internally available, because it is not in the SME's nature to cocreate, or because they lack the resources to involve customers. When SMEs engage in cocreation, it is because they see the value added or because customers initiate the process. Considering actual customer requirements for servitized offerings, I create a taxonomy that highlights the pricing strategy, a solid customer-supplier relationship, and being a reliable service provider as important criteria for all strategies. In addition, alignment with the internal processes of the customer, consideration of the end-customer, and an offering's contribution to the long-term sustainability of the customer organization are important for servitization strategies that radically change the business models of both the customer and the supplier. For servitization strategies that have less impact on the business models, priorities focused on the servitized offering and its proper functioning are more important, such as a quick response from the service provider, tangible design 
aspects, and feedback and training on how to use the offering. Taking my taxonomy as a starting point to design new offerings should help manufacturing SMEs increase their chances of servitization success.

\section{Synthesis}

The answer to the overarching research question of this dissertation - What are the drivers of SME innovation performance? - is grounded in the central premise of the systems of innovation approach (Edquist, 1997). This theory poses that "innovation is an interactive process that requires intensive communication and collaboration between different actors, both within companies as well as between firms or other organizations, such as universities, financing institutions or government agencies" (Tödtling and Trippl, 2005, p. 1205). In the research model in Figure 5.1 I omit the chapters to highlight how the different actors - both internal and external to the SME - influence innovation performance outcomes. According to the studies that constitute this dissertation, internal employees, external policy makers, customers, and other innovation partners (e.g., suppliers, competitors, universities) all contribute to an SME's innovation performance. Policy makers can stimulate employee involvement by launching subsidy programs, which not only increase employee involvement but also encourage collaboration with diverse external innovation partners, thereby enhancing the SME's ability to extract and utilize valuable external knowledge to improve innovation performance. I explicitly focus on how the three central actors in this dissertation (SMEs, policy makers, and customers) can enhance SMEs' innovation performance.

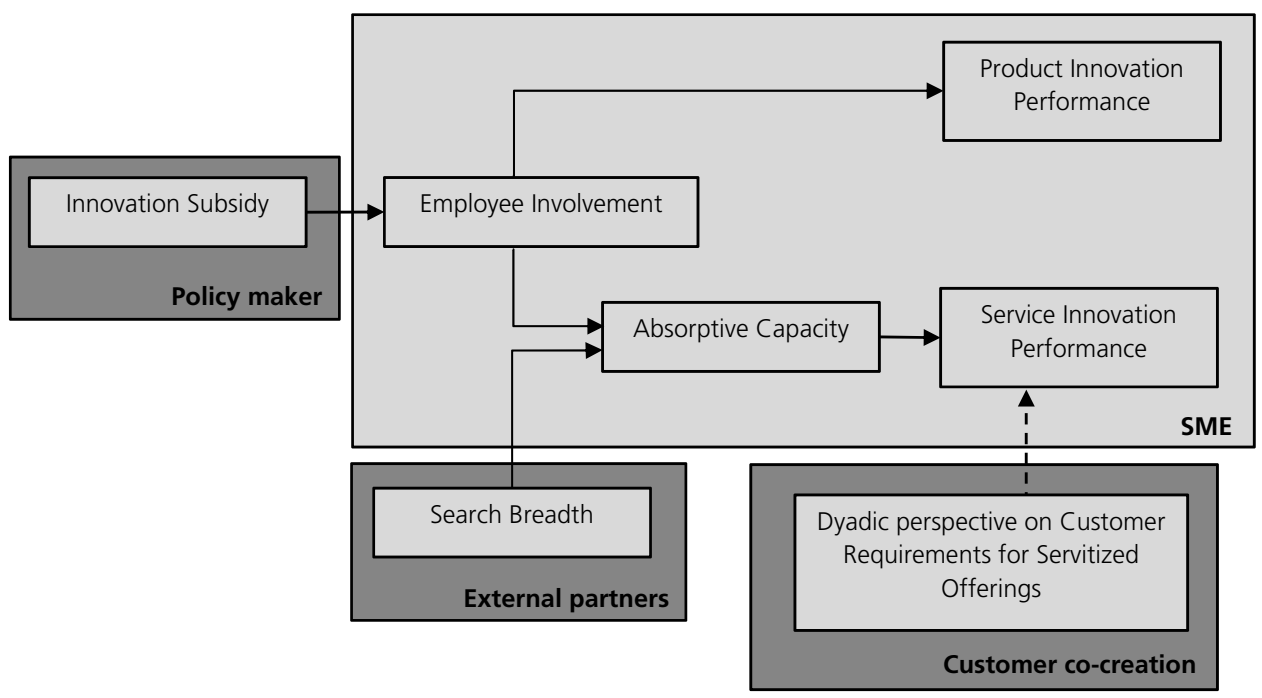

Figure 5.1. Research model depicting different actors in SME innovation process 


\section{SMES}

This dissertation offers clear insights into how collaboration can contribute to a manufacturing SME's innovation performance. Chapters 2 and 3 demonstrate that internal collaboration is crucial; if SME managers stimulate employee involvement, the SME will gain a greater ability to recognize and leverage valuable information from its external environment. This knowledge processing capability can enhance competitive advantages, through both product (Fosfuri and Tribó, 2008) and service innovation. The findings in Chapter 3 further indicate that external collaborations with a diverse set of innovation partners - including customers, suppliers, competitors, government, and universities enhance knowledge processing capabilities too. In Chapter 4, I determine that too many SMEs do not engage in co-creation with their customers for service innovation. In light of the growing share of SMEs that provide services, the importance of customer cocreation has increased too, as a means to ensure that new servitized offerings align with customer needs.

Moreover, SME managers' awareness of and application for public funding opportunities and innovation subsidies can be of great value to an SME's innovation performance. Innovation subsidies provide SMEs with direct financial resources to support innovation projects. These financial resources help ensure that human resources - in the form of employee involvement - are dedicated to innovation beyond the scope of a specific innovation project. Ultimately, it can lead to enhanced innovation performance.

\section{Policy makers}

Innovating SMEs grow twice as fast as firms that fail to innovate (EU Publications, 2017). However, a lack of financial and human resources often inhibits their innovation (Freel, 2000; Madrid-Guijarro, Garcia and Van Auken, 2009). Policy makers therefore should help SMEs overcome these barriers by providing financial resources, in the form of innovation subsidies. Economists and policy makers agree on the need to stimulate innovation (EU Publications, 2017) and the importance of evaluating public innovation policies (González and Pazó, 2008). In Chapter 2, I cite the increasing awareness among policy makers that SME interactions with innovation policy instruments affect the firm's behaviour, even after it has received public support (Clarysse et al., 2009). By identifying innovation subsidies as drivers of employee involvement, I also provide an entirely new rationale for public investments in subsidy programs, because the structural involvement of employees enhances the innovation process and SMEs' innovation performance. Because the increase in employee involvement is structural, such that it extends beyond the specific innovation project to which a subsidy is dedicated, subsidy programs appear to offer effective tools for strengthening innovation in SMEs.

The results in Chapter 3 also indicate another opportunity for policy makers to drive SME innovation performance, because they show that collaborations with diverse sets of external innovation partners increase the SME's ability to recognize and use valuable 
external knowledge, to the benefit of its innovation performance. Policy makers should stimulate cooperation between SMEs and diverse partners, spanning the local government, suppliers, customers, competitors, and universities, by creating more incentives to collaborate and facilitating platforms for doing so. Network events could bring different actors together to help them find potential synergies for innovation collaboration. Spurring collaboration between SMEs and their customers seems especially promising, because customer co-creation is vital to servitization success (Storey et al., 2016), yet only half of the servitizing SMEs in my sample currently co-create with their customers.

\section{Customers}

Customers of manufacturing SMEs should be proactive in expressing their needs and wants. In Chapter 4, I find that about half of the SMEs co-create with their customers to devise new servitized offerings, for which a customer-centric focus is vital (Vargo and Lusch, 2004), such that customer involvement will improve the alignment between the offering and customer needs. My interviews with representatives of customer firms show that customers can express their requirements, but only a few of them initiate their own involvement in the development of new servitized offerings. If customer firms start the co-creation process by clearly articulating their needs, there is a higher chance that they can be directly involved in this development, which ultimately should increase their satisfaction with the SME's offerings.

\section{Directions for further research}

Beyond these insights into how to increase the innovation performance of manufacturing SMEs, this dissertation suggests several valuable avenues for continued research that can advance knowledge on this topic even further. Each chapter details several specific directions; in this section, I take a broader perspective on the research conducted with my co-authors for this dissertation to contemplate novel ways to investigate innovation efforts by manufacturing SMEs.

The greatest opportunities - and also the greatest challenges - for advancing literature on innovation by SMEs likely stem from orchestrated data collection. Most SME innovation research still relies on cross-sectional data (Love and Roper, 2015), but such studies cannot explain why correlations exist or eliminate external influences completely (Humphreys, McAdam and Leckey, 2005). Longitudinal research offers a solution, but it is costly and time consuming (Humphreys et al., 2005). The notoriously low survey response rates from small business owners also mean that independently collecting longitudinal data at a large enough scale to conduct meaningful analyses is difficult (Brinkerink, 2018). Some academics use panel data sets from existing databases (e.g. González and Pazó, 2008; Karhunen and Huovari, 2015; Roper and Hewitt-Dundas, 2016), but doing so limits their ability to construct their research, because the items included in the surveys have been predetermined by others. 
The data collection methods I employed involved primary sources (SMEs and their customers), participating in the LimburgMakers subsidy program, and the data gathering efforts were supported by the province of Limburg and LIOF. By using their existing networks and displaying their trademarks in all communications with the participants, I enlarged my potential pool of participants and gained credibility for my research projects. Combined with relentless attempts to gather responses (i.e., via mail, e-mail, phone calls, and company visits), I achieved a response rate of $37.4 \%$ for the second wave of data collection, after an initial participation rate of $14.4 \%$ for the first survey. In turn, I could compile the longitudinal data set for Chapter 2. Additional inquiries might adopt a similar approach and join forces with local governments and industry to enhance data collection efforts. For example, connecting a research project to a specific subsidy program might support a mandate that recipient SMEs must participate in the research to receive the subsidy. Research based on such self-collected, longitudinal data sets may provide even more interesting and robust contributions to SME innovation theory, especially with regard to whether receiving an innovation subsidy has other behavioural effects on the organization, such as hiring or training routines, beyond increasing employee involvement.

Another opportunity comes from elaborating on the findings, using the novel methodology from Chapter 4. I acted as a sort of bridge between the servitizing manufacturing SMEs and their customers. Reviewing new servitized offering ideas by the SMEs and explaining them to potential customers served as a sort of triple-edged sword. First, I gained unique insights into customer requirements for servitized offerings and thus could construct the proposed taxonomy for different servitization strategies. Second, the research helped the SMEs shape and position their servitized offerings. Third, this approach granted SME customers an opportunity to voice their needs and priorities. Initiatives that build on this foundation might expand theory on how to servitize successfully, while also truly assisting servitizing SMEs in devising new servitized offerings in reality. A related and potentially interesting avenue for research would be to investigate co-creation and customer requirements throughout the entire development process; the intensity of co-creation activities likely varies across different stages of the development process (Fliess and Lexutt, 2017), and customer requirements for servitized offerings also might change over time. Insights into these fluctuations would provide servitizing SMEs with invaluable information about how to position and develop their servitized offerings.

Another fruitful avenue for further research relates to the rapidly changing landscape in which SMEs are operating. Industry 4.0 and digitization open up opportunities for new types of innovation such as Internet of Things solutions and smart factories. These innovations allow SMEs to revolutionize inflexible processes with high-performance computers and intelligent products and machines via active exchange of information (Sommer, 2015). However, SMEs are not ready for the challenges these type of innovations demand in terms of new business models and employee training (Sommer, 2015). This issues a need for guidance and public support beyond providing financial assistance (Issa, 
Lucke and Bauernhansl, 2017). Future research could investigate how policy makers can aid SMEs in overcoming these new barriers associated with modern types of innovation.

Another interesting development takes place within the needs of the workforce. Today, employees increasingly value the possibility to "work smarter", which means being able to work everywhere, at any time (VodafoneZiggo and EY, 2018). Therefore, to remain attractive employers, SMEs need to provide employees with the tools that facilitate this new way of working. In turn, this will lead to increased levels of employee satisfaction and effectiveness. In light of this increased effectiveness, future inquiries could research how "smart working" affects internal innovation collaboration routines such as employee involvement, because colleagues will more often have meetings via platforms such as Skype for business instead of face-to-face meetings at the office.

\section{Final thoughts}

The research reported in this dissertation provides a multi-actor perspective on how innovation performance of manufacturing SMEs can be enhanced. Perhaps more importantly, it provides an example of how academics and practitioners can come together to disseminate research that advances theory while also establishing meaningful results for policy makers and SMEs. Considering the importance of innovation in SMEs, I hope this work inspires readers to adopt similar approaches to advance knowledge on this topic even further. 

References 

Acs, Z. J., \& Audretsch, D. B. (1988). Innovation in large and small firms: an empirical analysis. The American economic review, 78(4), 678-690.

Aerts, K., \& Schmidt, T. (2008). Two for the price of one? Additionality effects of R\&D subsidies: A comparison between Flanders and Germany. Research Policy, 37, 806-822.

Aldrich, H., \& Herker, D. (1977). Boundary spanning roles and organization structure. Academy of Management Review, 2(2), 217-230.

Alegre, J., Sengupta, K., \& Lapiedra, R. (2013). Knowledge management and innovation performance in a high-tech SMEs industry. International Small Business Journal, 31(4), 454-470.

Alghisi, A., \& Saccani, N. (2015). Internal and external alignment in the servitization journeyovercoming the challenges. Production Planning \& Control, 26(14-15), 1219-1232.

Alpkan, L., Yilmaz, C., \& Kaya, N. (2007). Market orientation and planning flexibility in SMEs: performance implications and an empirical investigation. International Small Business Journal, 25(2), 152-172.

Amah, E., \& Ahiauzu, A. (2013). Employee involvement and organizational effectiveness. Journal of Management Development, 32(7), 661-674.

Ambroise, L., Prim-Allaz, I., Teyssier, C., \& Peillon, S. (2018). The environment-strategy-structure fit and performance of industrial servitized SMEs. Journal of Service Management, 29(2), 301-328.

Anderson, N. R., \& West, M. A. (1998). Measuring climate for work group innovation: development and validation of the team climate inventory. Journal of Organizational Behavior: The International Journal of Industrial, Occupational and Organizational Psychology and Behavior, 19(3), 235-258.

Andries, P., \& Czarnitzki, D. (2014). Small firm innovation performance and employee involvement. Small Business Economics, 43(1), 21-38.

Antioco, M., Moenaert, R. K., Lindgreen, A., \& Wetzels, M. G. (2008). Organizational antecedents to and consequences of service business orientations in manufacturing companies. Journal of the Academy of Marketing Science, 36(3), 337-358.

Antonioli, D., Marzucchi, A., \& Montresor, S. (2014). Regional innovation policy and innovative organizations: looking for additional effects. European Planning Studies, 22(1), 64-83.

Armstrong, J. S., \& Overton, T. S. (1977). Estimating nonresponse bias in mail surveys. Journal of Marketing Research, 396-402.

Arvanitis, S., Donzé, L., \& Sydow, N. (2010). Impact of Swiss technology policy on firm innovation performance: an evaluation based on a matching approach. Science and Public Policy, 37(1), 63-78.

Atuahene-Gima, K. (1996). Differential potency of factors affecting innovation performance in manufacturing and services firms in Australia. Journal of Product Innovation Management 13(1): 35-52.

Autio, E., Kanninen, S., \& Gustafsson, R. (2008). First-and second-order additionality and learning outcomes in collaborative R\&D programs. Research Policy, 37(1), 59-76.

Bagozzi, R. P., \& Yi, Y. (1988). On the evaluation of structural equation models. Journal of the Academy of Marketing Science, 16(1), 74-94.

Baines, T. S., Lightfoot, H. W., Benedettini, O., \& Kay, J. M. (2009). The servitization of manufacturing: A review of literature and reflection on future challenges. Journal of Manufacturing Technology Management, 20(5), 547-567.

Baines, T., Ziaee Bigdeli, A., Bustinza, O. F., Shi, V. G., Baldwin, J., \& Ridgway, K. (2017). Servitization: revisiting the state-of-the-art and research priorities. International Journal of Operations \& Production Management, 37(2), 256-278.

Balasubramanian, N., \& Lee, J. (2008). Firm age and innovation. Industrial and Corporate Change, 17(5), 1019-1047.

Basco, R. (2014). Exploring the influence of the family upon firm performance: Does strategic behaviour matter? International Small Business Journal, 32(8), 967-995. 
Battisti, M., \& Deakins, D. (2017). The relationship between dynamic capabilities, the firm's resource base and performance in a post-disaster environment. International Small Business Journal, 35(1), 78-98.

Baum, J. R., Locke, E. A., \& Smith, K. G. (2001). A multidimensional model of venture growth. Academy of Management Journal, 44(2), 292-303.

Beck, M., Lopes-Bento, C., \& Schenker-Wicki, A. (2016). Radical or incremental: Where does R\&D policy hit? Research Policy, 45(4), 869-883.

Becker, J. M., Klein, K., \& Wetzels, M. (2012). Hierarchical latent variable models in PLS-SEM: guidelines for using reflective-formative type models. Long Range Planning, 45(5-6), 359-394.

Becker, S. O., \& Ichino, A. (2002). Estimation of average treatment effects based on propensity scores. The Stata Journal, 2(4), 358-377.

Bendapudi, N., \& Leone, R. P. (2002). Managing business-to-business customer relationships following key contact employee turnover in a vendor firm. Journal of Marketing, 66(2), 83-101.

Benedettini, O., Davies, J., \& Neely, A. (2015). A capability-based view of service transitions. Working Paper, University of Cambridge, Cambridge. Available at: http:// cambridgeservicealliance.eng.cam.ac.uk/resources/ Downloads/Monthly\%20Papers/2015April_ Capabilitybasedviewofservicetransition.pdf.

Benson, D., \& Ziedonis, R. H. (2009). Corporate venture capital as a window on new technologies: Implications for the performance of corporate investors when acquiring startups. Organization Science, 20(2), 329-351.

Berchicci, L., de Jong, J. P., \& Freel, M. (2015). Remote collaboration and innovative performance: the moderating role of R\&D intensity. Industrial and Corporate Change, 25(3), 429-446.

Berger, A. N., \& Udell, G. F. (1995). Relationship lending and lines of credit in small firm finance. Journal of Business, 68(3) 351-381.

Berry, L. L., Shankar, V., Parish, J. T., Cadwallader, S., \& Dotzel, T. (2006). Creating new markets through service innovation. MIT Sloan Management Review, 47(2), 56.
Bessant, J. (1999). The rise and fall of Supernet': a case study of technology transfer policy for smaller firms. Research Policy, 28(6), 601-614.

Bishop, K., D'Este, P., \& Neely, A. (2011). Gaining from interactions with universities: Multiple methods for nurturing absorptive capacity. Research Policy, 40(1), 30-40.

Bitner, M. J., Ostrom, A. L., \& Morgan, F. N. (2008). Service blueprinting: a practical technique for service innovation. California management review, 50(3), 66-94.

Blindenbach-Driessen, F., \& Van den Ende, J. (2014). The locus of innovation: The effect of a separate innovation unit on exploration, exploitation, and ambidexterity in manufacturing and service firms. Journal of Product Innovation Management, 31(5), 1089-1105.

Brettel, M., \& Rottenberger, J. D. (2013). Examining the link between entrepreneurial orientation and learning processes in small and medium-sized enterprises. Journal of Small Business Management, 51(4), 471-490.

Brinkerink, J. A. H. (2018). Innovation Management in Small and Medium-Sized Family Firms: The Role of Family-Induced Differences in Attitudes and Decision Models. Doctoral thesis, Maastricht University.

Brooks, A. C. (2000). Public subsidies and charitable giving: crowding out, crowding in, or both? Journal of Policy Analysis and Management, 19 (3), 451-464.

Brunswicker, S., \& Vanhaverbeke, W. (2015). Open innovation in small and medium-sized enterprises (SMEs): External knowledge sourcing strategies and internal organizational facilitators. Journal of Small Business Management, 53(4), 1241-1263.

Buisseret, T., Cameron, H. and Georghiou, L. (1995). What difference does it make additionality in the public support of R\&D in large firms. International Journal of Technology Management 10(4-6): 587-600.

Busom, I., \& Fernández-Ribas, A. (2008). The impact of firm participation in R\&D 
programmes on R\&D partnerships. Research Policy, 37(2), 240-257.

Busso, M., DiNardo, J., \& McCrary, J. (2014). New evidence on the finite sample properties of propensity score reweighting and matching estimators. Review of Economics and Statistics, 96(5), 885-897.

Caliendo, M., \& Kopeinig, S. (2008). Some practical guidance for the implementation of propensity score matching. Journal of Economic Surveys, 22(1), 31-72.

Caloffi, A., Rossi, F., \& Russo, M. (2015). What makes SMEs more likely to collaborate? Analysing the role of regional innovation policy. European Planning Studies, 23(7), 1245-1264.

Carbonell, P., Rodríguez-Escudero, A. I., \& Pujari, D. (2009). Customer involvement in new service development: An examination of antecedents and outcomes. Journal of product innovation management, 26(5), 536-550.

Cassiman, B., \& Golovko, E. (2011). Innovation and internationalization through exports. Journal of International Business Studies, 42(1), 56-75.

Castrogiovanni, G. J. (2011). The role of human capital factors in small business performance and success. In C. Cooper \& R. Burke (Eds.), Human Resource Management in Small Business: Achieving Peak Performance (pp. 71-92). Cheltenham: Edward Elgar.

Caves, R., \& Porter, M. 1977. From entry business: conjectural decisions and contrived deterrence to new competition. Quarterly Journal of Economics, 91(2), 241-262.

Cepeda-Carrion, G., Cegarra-Navarro, J. G., \& Jimenez-Jimenez, D. (2012). The effect of absorptive capacity on innovativeness: Context and information systems capability as catalysts. British Journal of Management, 23(1), 110-129.

Cerulli, G., 2010. Modelling and measuring the effect of public subsidies on business R\&D: A critical review of the econometric literature. The Economic Record, 86(274), 421-449.

Cerulli, G., Gabriele, R., \& Potì, B. (2016). The role of firm R\&D effort and collaboration as mediating drivers of innovation policy effectiveness. Industry and Innovation, 23(5), 426-447.

Chávez, S. M. (2011). Behavioural additionality in the context of regional innovation policy in Spain. Innovation, 13(1), 95-110.

Chapman, G., \& Hewitt-Dundas, N. (2018). The effect of public support on senior manager attitudes to innovation. Technovation, 69, 28-39.

Chen, C., \& Huang, Y. (2010). Creative workforce density, organizational slack, and innovation performance. Journal of Business Research, 63(4), 411-417.

Chen, Y. S., Lin, M. J. J., \& Chang, C. H. (2009). The positive effects of relationship learning and absorptive capacity on innovation performance and competitive advantage in industrial markets. Industrial Marketing Management, 38(2), 152-158.

Chesbrough, H. (2011). The case for open services innovation: the commodity trap. California Management Review, 53(3), 5-20.

Chin, W. (1998). The partial least squares approach to structural equation modelling. In G. Marcoulides (Ed.), Modern Methods for Business Research. Mahwah, NJ: Lawrence Erlbaum Associates, 295-336.

Chirico, F., \& Nordqvist, M. (2010). Dynamic capabilities and trans-generational value creation in family firms: The role of organizational culture. International Small Business Journal, 28(5), 487-504.

Clarysse, B., Bilsen, V., Steurs, G., \& Consult, I. (2006). Behavioural additionality of the R\&D subsidies programme of IWT-Flanders (Belgium). In OECD (Ed.) Government R\&D Funding and Company Behaviour: Measuring Behavioural Additionality (pp. 91-114). Paris: OECD.

Clarysse, B., Wright, M., \& Mustar, P. (2009). Behavioural additionality of R\&D subsidies: A learning perspective. Research Policy, 38(10), 1517-1533.

Classen, N., Van Gils, A., Bammens, Y., \& Carree, M. (2012). Accessing resources from innovation partners: The search breadth of family SMEs. Journal of Small Business Management, 50(2), 191-215.

Clegg, B., Little, P., Govette, S., \& Logue, J. (2017). Transformation of a small-to-medium- 
sized enterprise to a multi-organisation productservice solution provider. International Journal of Production Economics, 192, 81-91.

Cohen, J., \& Cohen, P. (1983). Applied Multiple Regression/Correlation Analysis for The Behavioral Sciences. Hillsdale, NJ: Lawrence Erlbaum Associates.

Cohen, W., \& Levinthal, D. (1990). Absorptive capacity: A new perspective on learning and innovation. Administrative Science Quarterly 35, 128-152.

Cohen, W., \& Levinthal, D. (1994). Fortune favors the prepared firm. Management Science, 40(2), 227-251.

Cooper, R. G., \& Edgett, S. J. (1999). Product development for the service sector: lessons from market leaders. Perseus Books, Cambridge, MA.

Cunningham, P., \& Gök, A. (2012). The impact and effectiveness of policies to support collaboration for R\&D and innovation. NESTA Working Paper, 12(06). London: NESTA.

Czarnitzki, D., Ebersberger, B., \& Fier, A. (2007). The relationship between R\&D collaboration, subsidies and R\&D performance: empirical evidence from Finland and Germany. Journal of Applied Econometrics, 22(7), 1347-1366.

Czarnitzki, D., \& Hussinger, K. (2004). The Link between $R \& D$ Subsidies, $R \& D$ Spending and Technological Performance. Mannheim: Centre for European Economic Research (ZEW).

Czarnitzki, D., \& Licht, G. (2006). Additionality of public R\&D grants in a transition economy. Economics of Transition, 14(1), 101-131.

Czarnitzki, D., \& Lopes-Bento, C. (2014). Innovation subsidies: Does the funding source matter for innovation intensity and performance? Empirical evidence from Germany. Industry and Innovation, 21(5), 380-409.

Dada, O., \& Fogg, H. (2016). Organizational learning, entrepreneurial orientation, and the role of university engagement in SMEs. International Small Business Journal, 34(1), 86-104.

Darcy, C., Hill, J., McCabe, T. J., \& McGovern, P. (2014). A consideration of organisational sustainability in the SME context: A resource-based view and composite model. European Journal of Training and Development, 38(5), 398-414.

Davenport, S., Grimes, C., \& Davies, J. (1998). Research collaboration and behavioural additionality: a New Zealand case study. Technology Analysis \& Strategic Management, 10(1), 55-68.

De Brentani, U. (1989). Success and failure in new industrial services. Journal of Product Innovation Management 6(4), 239-528.

De Clercq, D., Dimov, D., \& Thongpapanl, N. (2015). Structural and relational interdependence and entrepreneurial orientation in small and medium-sized enterprises: The mediating role of internal knowledge-sharing. International Small Business Journal, 33(5), 514-536.

De Jong, J. P., \& Vermeulen, P. A. (2006). Determinants of product innovation in small firms: A comparison across industries. International small business journal, 24(6), 587-609.

Denison, D. R. (1984). Bringing corporate culture to the bottom line. Organizational Dynamics, 13(2), 5-22.

Dess, G. G., \& Robinson Jr, R. B. (1984). Measuring organizational performance in the absence of objective measures: the case of the privately-held firm and conglomerate business unit. Strategic Management Journal, 5(3), 265-273.

Diamantopoulos, A., Riefler, P., \& Roth, K. P. (2008). Advancing formative measurement models. Journal of Business Research, 61(12), 1203-1218.

Drew, S. A. (1997). From knowledge to action: the impact of benchmarking on organizational performance. Long Range Planning, 30(3), 427-441.

Dubois, A., \& Gibbert, M. (2010). From complexity to transparency: managing the interplay between theory, method and empirical phenomena in IMM case studies. Industrial Marketing Management, 39(1), 129-136.

Edquist, C. (ed.) (1997) Systems of Innovation - Technologies, Institutions and Organizations. London/Washington: Pinter.

Eisenhardt, K. M. (1989). Building theories from case study research. Academy of management review, 14(4), 532-550. 
Eisenhardt, K. M., \& Martin, J. A. (2000). Dynamic capabilities: what are they? Strategic Management Journal, 21(10-11), 1105-1121.

EU Publications (2017). Annual report on European SMEs 2016/2017. Retrieved June 22, 2018 from: https://publications.europa.eu/ en/publication-detail/-/publication/0b7b64b6ca80-11e7-8e69-01aa75ed71a1/language-en

European Commission (2013). Lessons from a decade of innovation policy. Retrieved June 6, 2018 from: https://ec.europa.eu/docsroom/ documents/5220/attachments/1/translations/ en/renditions/pdf

European Commission (2018). Infographic: Presents the latest data on European SMEs based on the annual report. Retrieved June 22, 2018 from: https://ec.europa.eu/docsroom/ documents/26563/attachments/5/translations/ en/renditions/native

European Service Innovation Centre (2013). Summary assessment of the Province of Limburg. Retrieved June 29, 2018 from: http:// ec.europa.eu/DocsRoom/documents/5124/ attachments/1/translations/en/renditions/native

Evanschitzky, H., Wangenheim, F. V., \& Woisetschläger, D. M. (2011). Service \& solution innovation: Overview and research agenda. Industrial Marketing Management, 40(5), 657-660.

Fainshmidt, S., \& Frazier, M. L. (2017). What facilitates dynamic capabilities? The role of organizational climate for trust. Long Range Planning, 50(5), 550-566.

Falk, R. (2007). Measuring the effects of public support schemes on firms' innovation activities: Survey evidence from Austria. Research Policy, 36(5), 665-679.

Falk, R., \& Miller, N. (1992). A Primer for Soft Modeling. Akron, $\mathrm{OH}$ : University of Akron Press.

Fier, A., Aschhoff, B., \& Löhlein, H. (2006). Behavioural additionality of public R\&D funding in Germany. Government R\&D Funding and Company Behaviour: Measuring Behavioural Additionality (pp. 127 - 149). Paris: OECD.
Flatten, T. C., Greve, G. I., \& Brettel, M. (2011). Absorptive capacity and firm performance in SMEs: The mediating influence of strategic alliances. European Management Review, 8(3), 137-152.

Fliess, S. and Lexutt, E. (2017), "How to be successful with servitization - guidelines for research and management", Industrial Marketing Management (in press, corrected proof), available at: https://doi.org/10.1016/j. indmarman.2017.11.012 (accessed June 6, 2018)

Fornell, C. (1987). A second generation of multivariate analysis: Classification of methods and implications for marketing research. In $\mathrm{M}$. Houston (Ed.), Review of Marketing. Chicago, IL: American Marketing Association, 407-450.

Fornell, C., \& Larcker, D. F. (1981). Evaluating structural equation models with unobservable variables and measurement error. Journal of marketing research, 39-50.

Fosfuri, A., \& Tribó, J. A. (2008). Exploring the antecedents of potential absorptive capacity and its impact on innovation performance. Omega, 36(2), 173-187.

Freel, M. S. (2000). Barriers to product innovation in small manufacturing firms. International Small Business Journal, 18(2), 60-80.

Freiling, J., \& Dressel, K. (2015). Exploring constrained rates of adoption of total cost of ownership models: A service-dominant logic analysis. International Small Business Journal, 33(7), 774-793.

Frenk, J. (1992). Balancing relevance and excellence: organizational responses to link research with decision making. Social Science \& Medicine, 35(11), 1397-1404.

Frölich, M. (2004). Finite-sample properties of propensity-score matching and weighting estimators. Review of Economics and Statistics, 86(1), 77-90.

Gaiardelli, P., Martinez, V., \& Cavalieri, S. (2015). The strategic transition to services: a dominant logic perspective and its implications for operations. Production Planning \& Control 26(14-15), 1165-1170. 
Gaiardelli, P., Songini, L., \& Saccani, N. (2014). The automotive industry: heading towards servitization in turbulent times. In Servitization in Industry (pp. 55-72). Springer, Cham.

Gebauer, H. (2008). Identifying service strategies in product manufacturing companies by exploring environment - strategy configurations. Industrial Marketing Management, 37(3), 278-291.

Gebauer, H., Edvardsson, B., Gustafsson, A., \& Witell, L. (2010). Match or mismatch: strategystructure configurations in the service business of manufacturing companies. Journal of Service Research, 13(2), 184-197.

Gebauer, H., Fleisch, E., \& Friedli, T. (2005). Overcoming the service paradox in manufacturing companies. European Management Journal, 23(1), 14-26.

Gebauer, H., Gustafsson, A., \& Witell, L. (2011). Competitive advantage through service differentiation by manufacturing companies. Journal of business research, 64(12), 1270-1280.

Gebauer, H., Krempl, R., Fleisch, E., \& Friedli, T. (2008). Innovation of product-related services. Managing Service Quality: An International Journal, 18(4), 387-404.

Gebauer, H., Paiola, M., \& Edvardsson, B. (2010). Service business development in small and medium capital goods manufacturing companies. Managing Service Quality: An International Journal, 20(2), 123-139.

Gebauer, H., Paiola, M., \& Edvardsson, B. (2012). A capability perspective on service business development in small and mediumsized suppliers. Scandinavian Journal of Management, 28(4), 321-339.

Gebauer, H., Wang, C., Beckenbauer, B., \& Krempl, R. (2007). Business-to-business marketing as a key factor for increasing service revenue in China. Journal of Business \& Industrial Marketing, 22(2), 126-137.

Gebauer, H., Worch, H., \& Truffer, B. (2012). Absorptive capacity, learning processes and combinative capabilities as determinants of strategic innovation. European Management Journal, 30(1), 57-73.
Geneste, L., \& Galvin, P. (2015). Trust and knowledge acquisition by small and mediumsized firms in weak client-firm exchange relationships. International Small Business Journal, 33(3), 277-298.

Gómez-Mejía, L. R., Haynes, K. T., NúñezNickel, M., Jacobson, K. J., \& Moyano-Fuentes, J. (2007). Socioemotional wealth and business risks in family-controlled firms: Evidence from Spanish olive oil mills. Administrative Science Quarterly, 52(1), 106-137.

George, G. (2005). Slack resources and the performance of privately held firms. Academy of Management Journal, 48(4), 661-676.

Georghiou, L. (2002). Additionality and impact of R\&D subsidies. IWT Studies, 40, 57-64.

Georghiou, L., \& Clarysse, B. (2006). Introduction and synthesis, in government $R \& D$ funding and company behaviour. Measuring behavioural additionality, p. 243. Paris: OECD.

Georghiou, L., \& Roessner, D. (2000). Evaluating technology programs: tools and methods. Research Policy 29, 657-678.

Gök, A. (2010). Evolutionary Approach to Innovation Policy Evaluation: Behavioural Additionality and Organisational Routines. Manchester: University of Manchester.

Gök, A., \& Edler, J. (2012). The use of behavioural additionality evaluation in innovation policy making. Research Evaluation, 21(4), 306-318.

González, X., \& Pazó, C. (2008). Do public subsidies stimulate private $R \& D$ spending? Research Policy, 37(3), 371-389.

Green, M. H., Davies, P., \& Ng, I. C. (2017). Two strands of servitization: A thematic analysis of traditional and customer co-created servitization and future research directions. International Journal of Production Economics, 192, 40-53.

Hair, J., Hult, G., Ringle, C., et al. (2016). A Primer on Partial Least Squares Structural Equation Modeling (PLSSEM). Los Angeles: SAGE.

Hair, J. F., Ringle, C. M., \& Sarstedt, M. (2011). PLS-SEM: Indeed a silver bullet. Journal of Marketing Theory and Practice, 19(2), 139-152. 
Hair, J. F., Sarstedt, M., Pieper, T. M., \& Ringle, C. M. (2012). The use of partial least squares structural equation modeling in strategic management research: a review of past practices and recommendations for future applications. Long Range Planning, 45(5-6), 320-340.

Hakanen, T., \& Jaakkola, E. (2012). Co-creating customer-focused solutions within business networks: a service perspective. Journal of Service Management, 23(4), 593-611.

Hannan, M., \& Freeman, J. (1984). Structural inertia and organizational change. American sociological review, 49(2), 149-164.

He, Z. L., \& Wong, P. K. (2004). Exploration vs. exploitation: An empirical test of the ambidexterity hypothesis. Organization science, 15(4), 481-494.

Heckman, J. (1979). Sample selection bias as a specification error. Econometrica 47(1), 153-161.

Helfat, C. E., \& Peteraf, M. A. (2015). Managerial cognitive capabilities and the microfoundations of dynamic capabilities. Strategic Management Journal, 36(6), 831-850.

Helfat, C. E., \& Winter, S. G. (2011). Untangling dynamic and operational capabilities: Strategy for the (N) ever-changing world. Strategic Management Journal, 32(11), 1243-1250.

Helfat, C., Finkelstein, S., Mitchell, W., et al. (2009). Dynamic Capabilities: Understanding Strategic Change in Organizations. Hoboken, NJ: John Wiley \& Sons.

Henseler, J., Ringle, C., \& Sinkovics, R. (2009). The use of partial least squares path modeling in international marketing. Advances in International Marketing 20, 277-319.

Herrera, L., \& Nieto, M. (2008). The national innovation policy effect according to firm location. Technovation, 28(8), 540-550.

Herrera, L., \& Sánchez-González, G. (2013). Firm size and innovation policy. International Small Business Journal, 31(2), 137-155.

Herrmann, P., \& Nadkarni, S. (2014). Managing strategic change: The duality of CEO personality. Strategic Management Journal, 35(9), 1318-1342.
Herzog, P., \& Leker, J. (2010). Open and closed innovation-different innovation cultures for different strategies. International Journal of Technology Management, 52(3/4), 322-343.

Hewitt-Dundas, N., \& Roper, S. (2010). Output Additionality of Public Support for Innovation: Evidence for Irish Manufacturing Plants. European Planning Studies, 18(1), 107-122.

Hewitt-Dundas, N., \& Roper, S. (2018). Exploring market failures in open innovation. International Small Business Journal, 36(1), 23-40.

Hoffmann, C., Wulf, T., \& Stubner, S. (2016). Understanding the performance consequences of family involvement in the top management team: The role of long-term orientation. International Small Business Journal, 34(3), 345-368.

Hoffman, K., Parejo, M., Bessant, J., \& Perren, L. (1998). Small firms, R\&D, technology and innovation in the UK: a literature review. Technovation, 18(1), 39-55.

Hotho, J. J., Becker-Ritterspach, F., \& SakaHelmhout, A. (2012). Enriching absorptive capacity through social interaction. British Journal of Management, 23(3), 383-401.

Hottenrott, H., \& Lopes-Bento, C. (2014). (International) R\&D collaboration and SMEs: The effectiveness of targeted public R\&D support schemes. Research Policy, 43(6), 1055-1066.

Hsieh, Y., \& Chou, Y. (2018). Modeling the impact of service innovation for small and medium enterprises: A system dynamics approach. Simulation Modelling Practice and Theory, 82, 84-102.

Hsu, F. M., Horng, D. J., \& Hsueh, C. C. (2009). The effect of government-sponsored R\&D programmes on additionality in recipient firms in Taiwan. Technovation, 29(3), 204-217.

Huergo, E., \& Jaumandreu, J. (2004). How does probability of innovation change with firm age? Small Business Economics, 22(3-4), 193-207.

Hulland, J. (1999). Use of partial least squares (PLS) in strategic management research: A review of four recent studies. Strategic Management Journal, 20(2), 195-204. 
Humphreys, P., McAdam, R., \& Leckey, J. (2005). Longitudinal evaluation of innovation implementation in SMEs. European Journal of Innovation Management, 8(3), 283-304.

Imbens, G. W., \& Wooldridge, J. M. (2009). Recent developments in the econometrics of program evaluation. Journal of Economic Literature, 47(1), 5-86.

Islam, R., \& Zaki Hj. Ismail, A. (2008). Employee motivation: a Malaysian perspective. International Journal of Commerce and Management, 18(4), 344-362.

Issa, A., Lucke, D., \& Bauernhansl, T. (2017). Mobilizing SMEs Towards Industrie 4.0-enabled Smart Products. Procedia CIRP, 63, 670-674.

Jaakkola, E., \& Hakanen, T. (2013). Value co-creation in solution networks. Industrial Marketing Management, 42(1), 47-58.

Jansen, J. J., Van Den Bosch, F. A., \& Volberda, H. W. (2005). Managing potential and realized absorptive capacity: how do organizational antecedents matter? Academy of Management Journal, 48(6), 999-1015.

Kaiser, U. (2006). Private R\&D and public R\&D subsidies: Microeconometric evidence for Denmark. Nationaløkonomisk Tidsskrift, 144(1), 1-17.

Kanninen, T., Penttinen, E., Tinnilä, M., \& Kaario, K. (2017). Exploring the dynamic capabilities required for servitization: The case process industry. Business Process Management Journal, 23(2), 226-247.

Karhunen, H., \& Huovari, J. (2015). R\&D subsidies and productivity in SMEs. Small Business Economics, 45(4), 805-823.

Kastalli, I. V., \& Van Looy, B. (2013). Servitization: Disentangling the impact of service business model innovation on manufacturing firm performance. Journal of Operations Management, 31(4), 169-180.

Katz, R., \& Allen, T. J. (1982). Investigating the Not Invented Here $(\mathrm{NIH})$ syndrome: A look at the performance, tenure, and communication patterns of $50 \mathrm{R} \& \mathrm{D}$ Project Groups. R\&D Management, 12(1), 7-20.
Kelley, S. W. (1993). Discretion and the service employee. Journal of retailing, 69(1), 104-126.

Kevill, A., Trehan, K., \& Easterby-Smith, M. (2017). Perceiving 'capability' within dynamic capabilities: The role of owner-manager self-efficacy. International Small Business Journal, 35(8), 883-902.

Kindström, D., Kowalkowski, C., \& Sandberg, E. (2013). Enabling service innovation: A dynamic capabilities approach. Journal of Business Research, 66(8), 1063-1073.

Kleinbaum, A. M., \& Stuart, T. E. (2014). Network responsiveness: The social structural microfoundations of dynamic capabilities. Academy of Management Perspectives, 28(4), 353-367.

Klette, T., Moen, J., \& Grilliches, Z. (2000). Do subsidies to commercial $R \& D$ reduce market failure? Research Policy 29, 471-496.

Kogut, B., \& Zander, U. (1992). Knowledge of the firm, combinative capabilities, and the replication of technology. Organization science, 3(3), 383-397.

Kohli, A. K., \& Jaworski, B. J. (1990). Market orientation: the construct, research propositions, and managerial implications. The Journal of Marketing, 54, 1-18.

Kohtamäki, M., \& Partanen, J. (2016). Cocreating value from knowledge-intensive business services in manufacturing firms: the moderating role of relationship learning in supplier-customer interactions. Journal of Business Research, 69(7), 2498-2506.

Kohtamäki, M., Partanen, J., Parida, V., \& Wincent, J. (2013). Non-linear relationship between industrial service offering and sales growth: The moderating role of network capabilities. Industrial Marketing Management, 42(8), 1374-1385.

Kowalkowski, C., Kindström, D., \& Witell, L. (2011). Internalisation or externalisation? Examining organisational arrangements for industrial services. Managing Service Quality, 21(4), 373-391.

Kowalkowski, C., Witell, L., \& Gustafsson, A. (2013). Any way goes: Identifying value constellations for service infusion in SMEs. Industrial Marketing Management, 42(1), 18-30. 
La Rocca, A., Moscatelli, P., Perna, A., \& Snehota, I. (2016). Customer involvement in new product development in B2B: The role of sales. Industrial Marketing Management, 58, 45-57.

Lanero, A., Vázquez, J. L., \& Aza, C. L. (2016). Social cognitive determinants of entrepreneurial career choice in university students. International Small Business Journal, 34(8), 1053-1075.

Laursen, K., \& Salter, A. (2006). Open for innovation: the role of openness in explaining innovation performance among UK manufacturing firms. Strategic management journal, 27(2), 131-150.

Lechner, C., \& Gudmundsson, S. V. (2014). Entrepreneurial orientation, firm strategy and small firm performance. International Small Business Journal, 32(1), 36-60.

Leuven, E., \& Sianesi, B. (2018). PSMATCH2: Stata module to perform full Mahalanobis and propensity score matching, common support graphing, and covariate imbalance testing. https://ideas.repec.org/c/boc/bocode/s432001. html (accessed February 8, 2018).

Liang, H., Saraf, N., Hu, Q., \& Xue, Y. (2007). Assimilation of enterprise systems: the effect of institutional pressures and the mediating role of top management. MIS quarterly, 31(1), 59-87.

Liao, S. H., Fei, W. C., \& Liu, C. T. (2008). Relationships between knowledge inertia, organizational learning and organization innovation. Technovation, 28(4), 183-195.

Lightfoot, H. W., \& Gebauer, H. (2011). Exploring the alignment between service strategy and service innovation. Journal of Service Management, 22(5), 664-683.

Cox, R. (2013). Geld voor innovatieve producten. Limburgs Dagblad.

LIOF (2013). 5 vragen aan Twan Beurskens, gedeputeerde Provincie Limburg. Retrieved June 25, 2018 from: http://www.meerondernemen. nl/meer-ondernemen-nummer-9/5-vragen-aan/\# . W22kydlza70

Love, J. H., \& Roper, S. (2015). SME innovation, exporting and growth: A review of existing evidence. International Small Business Journal, 33(1), 28-48.

Lubatkin, M. H., Simsek, Z., Ling, Y., \& Veiga, J. F. (2006). Ambidexterity and performance in small-to medium-sized firms: The pivotal role of top management team behavioral integration. Journal of management, 32(5), 646-672.

Lusch, R., \& Vargo, S. (2006). ServiceDominant Logic as a Foundation for Building a General Theory. The Service-Dominant Logic of Marketing: Dialog, Debate and Directions, Lusch, R. and Vargo, S. eds. Armonk, NY: M.E. Sharpe, 406-420.

Lusch, R. F., Vargo, S. L., \& O'brien, M. (2007). Competing through service: Insights from servicedominant logic. Journal of Retailing, 83(1), 5-18.

Lytle, R. S., Hom, P. W., \& Mokwa, M. P. (1998). SERV*OR: A managerial measure of organizational service-orientation. Journal of Retailing, 74(4), 455-489.

Madrid-Guijarro, A., Garcia, D., \& Van Auken, H. (2009). Barriers to innovation among Spanish manufacturing SMEs. Journal of Small Business Management, 47(4), 465-488.

Maes, J., \& Sels, L. (2014). SMEs' radical product innovation: The role of internally and externally oriented knowledge capabilities. Journal of Small Business Management, 52(1), 141-163.

Martin Jr, C. R., \& Horne, D. A. (1992). Restructuring towards a service orientation: the strategic challenges. International Journal of Service Industry Management, 3(1), 25-38.

Masiello, B., Izzo, F., \& Canoro, C. (2015). The structural, relational and cognitive configuration of innovation networks between SMEs and public research organisations. International Small Business Journal, 33(2), 169-193.

Mathieu, V. (2001). Service strategies within the manufacturing sector: Benefits, costs and partnership. International Journal of Service Industry Management, 12(5), 451-475.

Matthyssens, P., \& Vandenbempt, K. (2008). Moving from basic offerings to value-added 
solutions: Strategies, barriers and alignment. Industrial Marketing Management, 37(3), 316-328.

Melton, H. L., \& Hartline, M. D. (2010). Customer and frontline employee influence on new service development performance. Journal of Service Research, 13(4), 411-425.

Melton, H. L., \& Hartline, M. D. (2013). Employee collaboration, learning orientation, and new service development performance. Journal of Service Research, 16(1), 67-81.

Mendes, L. (2012). Employees' involvement and quality improvement in manufacturing small and medium enterprise (SME): A comparative analysis. African Journal of Business Management, 6(23), 6980.

Mennens, K., Van Gils, A., OdekerkenSchröder, G., \& Letterie, W. (2018). Exploring antecedents of service innovation performance in manufacturing SMEs. International Small Business Journal, 36(5), 500-520.

Meuleman, M., \& De Maeseneire, W. (2012). Do R\&D subsidies affect SMEs' access to external financing? Research Policy, 41(3), 580-591.

Michel, S., Brown, S. W., \& Gallan, A. S. (2008). An expanded and strategic view of discontinuous innovations: deploying a servicedominant logic. Journal of the academy of marketing science, 36(1), 54-66.

Millimet, D. L., \& Tchernis, R. (2009). On the specification of propensity scores, with applications to the analysis of trade policies. Journal of Business \& Economic Statistics, 27(3), 397-415.

Mina, A., Bascavusoglu-Moreau, E., \& Hughes, A. (2014). Open service innovation and the firm's search for external knowledge. Research Policy, 43(5), 853-866.

Moreno, A. M., \& Casillas, J. C. (2008). Entrepreneurial orientation and growth of SMEs: A causal model. Entrepreneurship theory and practice, 32(3), 507-528.

Muscio, A. (2007). The impact of absorptive capacity on SMEs' collaboration. Economics of Innovation and New Technology, 16(8), 653-668.
Naman, J. L., \& Slevin, D. P. (1993). Entrepreneurship and the concept of fit: A model and empirical tests. Strategic Management Journal, 14(2), 137-153.

Neely, A. (2008). Exploring the financial consequences of the servitization of manufacturing. Operations Management Research, 1(2), 103-118.

Neicu, D., Teirlinck, P., \& Kelchtermans, S. (2016). Dipping in the policy mix: Do R\&D subsidies foster behavioral additionality effects of R\&D tax credits? Economics of Innovation and New Technology, 25(3), 218-239.

Nelson, R. \& Winter S. (1982). An Evolutionary Theory of Economic Change. Belknap Press: Cambridge, MA.

Nijssen, E. J., Hillebrand, B., Vermeulen, P. A., \& Kemp, R. G. (2006). Exploring product and service innovation similarities and differences. International Journal of Research in Marketing, 23(3), 241-251.

Nohria, N., \& Gulati, R. (1996). Is slack good or bad for innovation? Academy of management Journal, 39(5), 1245-1264.

Nolan, A. (2008). Evaluating the impact of eligibility for free care on the use of general practitioner (GP) services: a difference-indifference matching approach. Social Science \& Medicine, 67(7), 1164-1172.

Nooteboom, B. (1994). Innovation and diffusion in small firms: theory and evidence. Small Business Economics, 6(5), 327-347.

Norrman, C., \& Bager-Sjögren, L. (2010). Entrepreneurship policy to support new innovative ventures: Is it effective? International Small Business Journal, 28(6), 602-619.

Nutley, S., Walter, I., \& Davies, H. T. (2003). From knowing to doing: a framework for understanding the evidence-into-practice agenda. Evaluation, 9(2), 125-148.

OECD (2018). Enabling SMEs to scale up. Retrieved June 25, 2018 from: https://www.oecd. org/cfe/smes/ministerial/documents/2018-SMEMinisterial-Conference-Plenary-Session-1.pdf 
Oertzen, A. S., Odekerken-Schröder, G., Brax, S. A., \& Mager, B. (2018). Co-creating servicesconceptual clarification, forms and outcomes. Journal of Service Management.

Oliva, R., \& Kallenberg, R. (2003). Managing the transition from products to services. International journal of service industry management, 14(2), 160-172.

Ordanini, A., \& Parasuraman, A. (2011). Service innovation viewed through a servicedominant logic lens: a conceptual framework and empirical analysis. Journal of Service Research, 14(1), 3-23.

Ostrom, A. L., Bitner, M. J., Brown, S. W., Burkhard, K. A., Goul, M., Smith-Daniels, V., Demirkan, H., \& Rabinovich, E. (2010). Moving forward and making a difference: research priorities for the science of service. Journal of Service Research, 13(1), 4-36.

PA Consulting Group (2018). From products to services: Creating sustainable growth in industrial manufacturing through servitization. Retrieved August 6, 2018 from: http://www2. paconsulting.com/ Servitization_download. $\mathrm{html}$ ?_ga $=2.46980007 .1096946392 .1533912150-$ 692282910.1533549858

Paiola, M., Saccani, N., Perona, M., \& Gebauer, H. (2013). Moving from products to solutions: Strategic approaches for developing capabilities. European Management Journal, 31(4), 390-409.

Parasuraman, A., Zeithaml, V., \& Berry, L. (1985). A conceptual model of service quality and its implications for future research. Journal of Marketing, 49, 41-50.

Perkmann, M., \& Walsh, K. (2007). Universityindustry relationships and open innovation: Towards a research agenda. International Journal of Management Reviews, 9(4), 259-280.

Podsakoff, P. M., MacKenzie, S. B., Lee, J. Y., \& Podsakoff, N. P. (2003). Common method biases in behavioral research: A critical review of the literature and recommended remedies. Journal of Applied Psychology, 88(5), 879.

Poon, J. M., Ainuddin, R. A., \& Junit, S. O. H. (2006). Effects of self-concept traits and entrepreneurial orientation on firm performance. International Small Business Journal, 24(1), 61-82.

Porter, M. E. (1979). The structure within industries and companies' performance. The Review of Economics and Statistics, 214-227.

Pun, K. F., \& Chin, K. S. (1999). Bridging the needs and provisions of quality education and training: an empirical study in Hong Kong industries. International Journal of Quality \& Reliability Management, 16(8), 792-810.

Pun, K. F., Chin, K. S., \& Gill, R. (2001). Determinants of employee involvement practices in manufacturing enterprises. Total Quality Management, 12(1), 95-109.

Radas, S., \& Božić, L. (2009). The antecedents of SME innovativeness in an emerging transition economy. Technovation, 29(6-7), 438-450.

Raddats, C., Burton, J., \& Ashman, R. (2015). Resource configurations for services success in manufacturing companies. Journal of Service Management, 26(1), 97-116.

Raja, J. Z., Johnson, M., \& Goffin, K. (2015, January). Uncovering the competitive priorities for servitization: A repertory grid study. In Academy of Management Proceedings (Vol. 2015, No. 1, p. 11988). Academy of Management.

Raymond, L., \& St-Pierre, J. (2010). R\&D as a determinant of innovation in manufacturing SMEs: An attempt at empirical clarification. Technovation, 30(1), 48-56.

Reinartz, W. and Ulaga, W. (2008). "How to Sell Services Profitably." Harvard Business Review, 86(5), 90-98.

Rice, J., Liao, T. S., Galvin, P., \& Martin, N. (2015). A configuration-based approach to integrating dynamic capabilities and market transformation in small and medium-sized enterprises to achieve firm performance. International Small Business Journal, 33(3), 231-253.

Ringle, C., Wende, S., \& Becker, J. (2015). Smartp/s 3. Böenningstedt: SmartPLS GmbH. Available at: http://www.smartpls.com. 
Rohlfer, S. (2008). Employee involvement and participation in SMEs: a synthesis of extant research. Journal of Evolutionary Studies in Business, 3(1), 112-136.

Roper, S., \& Hewitt-Dundas, N. (2016). The legacy of public subsidies for innovation: input, output and behavioural additionality effects. Warwick: ERC (Enterprise Research Centre) Research Paper, (21).

Rosenbaum, P. R., \& Rubin, D. B. (1983). The central role of the propensity score in observational studies for causal effects. Biometrika, 70(1), 41-55.

Rosenbusch, N., Brinckmann, J., \& Bausch, A. (2011). Is innovation always beneficial? A metaanalysis of the relationship between innovation and performance in SMEs. Journal of business Venturing, 26(4), 441-457.

Rossi, F., Caloffi, A., \& Russo, M. (2016). Networked by design: Can policy requirements influence organisations' networking behaviour? Technological Forecasting and Social Change, 105, 203-214.

Rothaermel, F. T., \& Alexandre, M. T. (2009). Ambidexterity in technology sourcing: The moderating role of absorptive capacity. Organization Science, 20(4), 759-780.

Rubin, D. (2008). For objective causal inference, design trumps analysis. The Annals of Applied Statistics, 2(3), 808-840.

Ruiz-Moreno, A., Garcia-Morales, V. J., \& Llorens-Montes, F. J. (2008). The moderating effect of organizational slack on the relation between perceptions of support for innovation and organizational climate. Personnel Review, 37(5), 509-525.

Sameer, M., \& Özbilgin, M. F. (2014). Employee voice in the SME context. Handbook of Research on Employee Voice: Elgar original reference (pp. 410-420). Cheltenham: Edward Elgar.

Sastre, J., Vera, V., \& Eduardo, C. (2017). Cooperation for innovation in developing countries and its effects: evidence from Ecuador. Journal of Technology Management \& Innovation, 12(3), 48-57.
Saul, C. J., \& Gebauer, H. (2018). Born solution providers - Dynamic capabilities for providing solutions. Industrial Marketing Management (in press, corrected proof), available at: https:// doi.org/10.1016/j.indmarman.2018.01.007 (accessed Jun 3, 2018).

Sawhney, M., Wolcott, R. C., \& Arroniz, I. (2006). The 12 different ways for companies to innovate. MIT Sloan management review, 47(3), 75.

Schein, E. (2004). Organizational Culture and Leadership. San Francisco, CA: Jossey-Bass.

Schneider, B., \& Bowen, D. (1984). New service design, development and implementation and the employee. In W. George and C. Marshall (Eds.), Developing New Services. Chicago, IL: American Marketing Association, 82-101.

Schumpeter, J.A., 1942. Capitalism, Socialism and Democracy. Routledge, London, pp. 82-83.

Shah, D., Rust, R. T., Parasuraman, A., Staelin, R., \& Day, G. S. (2006). The path to customer centricity. Journal of service research, 9(2), 113-124.

Shankar, V., Berry, L. L., \& Dotzel, T. (2009). A practical guide to combining products services. Harvard Business Review, 87(11), 94-99.

Singh, J. V. (1986). Performance, slack, and risk taking in organizational decision making. Academy of Management Journal, 29(3), 562-585.

Sjödin, D. R., Parida, V., \& Kohtamäki, M. (2016). Capability configurations for advanced service offerings in manufacturing firms: Using fuzzy set qualitative comparative analysis. Journal of Business Research, 69(11), 5330-5335.

Slater, S., \& Narver, J. (1995). Market orientation and the learning organization. Journal of Marketing 59, 63-74.

Smith, J. A., \& Todd, P. E. (2005). Does matching overcome LaLonde's critique of nonexperimental estimators? Journal of Econometrics, 125(1), 305-353.

Sommer, L. (2015). Industrial revolution-industry 4.0: Are German manufacturing SMEs the first victims of this revolution? Journal of Industrial Engineering and Management, 8(5), 1512-1532. 
Sousa, C. M., Lengler, J. F., \& MartínezLópez, F. J. (2014). Testing for linear and quadratic effects between price adaptation and export performance: the impact of values and perceptions. Journal of Small Business Management, 52(3), 501-520.

Spring, M., \& Araujo, L. (2009). Service, services and products: rethinking operations strategy. International Journal of Operations \& Production Management, 29(5), 444-467.

Storey, C., \& Easingwood, C. (1998). The augmented service offering: A conceptualization and study of its impact on new service success. Journal of Product Innovation Management, 15(4), 335-351.

Storey, C., \& Hull, F. M. (2010). Service development success: a contingent approach by knowledge strategy. Journal of Service Management, 21(2), 140-161.

Storey, C., Cankurtaran, P., Papastathopoulou, P., \& Hultink, E. J. (2016). Success factors for service innovation: A meta-analysis. Journal of Product Innovation Management, 33(5), 527-548.

Storey, D. (2000). Six steps to heaven: Evaluating the impact of public policies to support small businesses in developed economies. In D. Sexton \& H. Landstrom (Eds.), Handbook of Entrepreneurship (pp. 176-193). Oxford: Blackwell.

Story, V. M., Raddats, C., Burton, J., Zolkiewski, J., \& Baines, T. (2017). Capabilities for advanced services: A multi-actor perspective. Industrial Marketing Management, 60, 54-68.

Sun, H., Kee Hui, I., Tam, A. Y., \& Frick, J. (2000). Employee involvement and quality management. The TQM Magazine, 12(5), 350-354.

Tanskanen, K., \& Aminoff, A. (2015). Buyer and supplier attractiveness in a strategic relationship-A dyadic multiple-case study. Industrial Marketing Management, 50, 128-141.

Teece, D. J. (1980). Economies of scope and the scope of the enterprise. Journal of Economic Behavior \& Organization, 1(3), 223-247.

Teece, D. J. (2007). Explicating dynamic capabilities: the nature and microfoundations of (sustainable) enterprise performance. Strategic Management Journal, 28(13), 1319-1350.

Teece, D. J., Pisano, G., \& Shuen, A. (1997). Dynamic capabilities and strategic management. Strategic Management Journal, 18(7), 509-533.

Terziovski, M. (2010). Innovation practice and its performance implications in small and medium enterprises (SMEs) in the manufacturing sector: a resource-based view. Strategic Management Journal, 31(8), 892-902.

Tether, B. S. (2002). Who co-operates for innovation, and why: an empirical analysis. Research Policy, 31(6), 947-967.

Todorova, G., \& Durisin, B. (2007). Absorptive capacity: Valuing a reconceptualization. Academy of Management Review, 32(3), 774-786.

Tödtling, F., \& Trippl, M. (2005). One size fits all?: Towards a differentiated regional innovation policy approach. Research policy, 34(8), 1203-1219.

Tsai, W. (2001). Knowledge transfer in intraorganizational networks: Effects of network position and absorptive capacity on business unit innovation and performance. Academy of Management Journal, 44(5), 996-1004.

Tuli, K. R., Kohli, A. K., \& Bharadwaj, S. G. (2007). Rethinking customer solutions: From product bundles to relational processes. Journal of Marketing, 71(3), 1-17.

Uhlaner, L. M., van Stel, A., Duplat, V., \& Zhou, H. (2013). Disentangling the effects of organizational capabilities, innovation and firm size on SME sales growth. Small Business Economics, 41(3), 581-607.

Ulaga, W., \& Reinartz, W. J. (2011). Hybrid offerings: how manufacturing firms combine goods and services successfully. Journal of marketing, 75(6), 5-23.

Valtakoski, A. (2017). Explaining servitization failure and deservitization: A knowledgebased perspective. Industrial Marketing Management, 60, 138-150.

Valtakoski, A., \&Witell, L. (2018). Service capabilities and servitized SME performance: contingency on 
firm age. International Journal of Operations \& Production Management, 38(4), 1144-1164.

Van de Ven, A. H. (1986). Central problems in the management of innovation. Management Science, 32(5), 590-607.

Van de Vrande, V., De Jong, J. P., Vanhaverbeke, W., \& De Rochemont, M. (2009). Open innovation in SMEs: Trends, motives and management challenges. Technovation, 29(6-7), 423-437.

Van Wijk, R., Van den Bosch, F., \& Volberda, H. (2001). The impact of knowledge depth and breadth of absorbed knowledge on levels of exploration and exploitation. Paper presented at the annual meeting of the Academy of Management, August 6th, Washington, DC.

Vandermerwe, S., \& Rada, J. (1988). Servitization of business: adding value by adding services. European management journal, 6(4), 314-324.

Vargo, S. L., \& Lusch, R. F. (2004). Evolving to a new dominant logic for marketing. Journal of marketing, 68(1), 1-17.

Vega-Jurado, J., Gutiérrez-Gracia, A., \& Fernández-de-Lucio, I. (2008). Analyzing the determinants of firm's absorptive capacity: beyond R\&D. R\&D Management, 38(4), 392-405.

Vickers, I., \& Lyon, F. (2014). Beyond green niches? Growth strategies of environmentallymotivated social enterprises. International Small Business Journal, 32(4), 449-470.

Visnjic, I., Wiengarten, F., \& Neely, A. (2016). Only the brave: Product innovation, service business model innovation, and their impact on performance. Journal of Product Innovation Management, 33(1), 36-52.

VodafoneZiggo \& EY (2018). The impacts of Smart Working. Retrieved August 22, 2018 from: https://www.vodafoneziggo.nl/documents/86/ Eindrapportage_Impact_meting_slim_ werken_2018.pdf

Volberda, H. W., Foss, N. J., \& Lyles, M. A. (2010). Perspective-Absorbing the concept of absorptive capacity: How to realize its potential in the organization field. Organization science, 21(4), 931-951.
Voss, C., Johnston, R., Silvestro, R., et al. (1992). Measurement of innovation and design performance in services. Design Management Journal 3(1), 40-46.

Vossen, R. W. (1998). Relative strengths and weaknesses of small firms in innovation. International small business journal, 16(3), 88-94.

Wanzenböck, I., Scherngell, T., \& Fischer, M. M. (2013). How do firm characteristics affect behavioural additionalities of public R\&D subsidies? Evidence for the Austrian transport sector. Technovation, 33(2-3), 66-77.

Welikala, D., \& Sohal, A. S. (2008). Total Quality Management and employees' involvement: A case study of an Australian organization. Total Quality Management, 19(6), 627-642.

Whittaker, D. H., Fath, B. P., \& Fiedler, A. (2016). Assembling capabilities for innovation: Evidence from New Zealand SMEs. International Small Business Journal, 34(1), 123-143.

WijLimburg (2018). Oproep Koninklijke Metaalunie: MKB innoveert te traag. Retrieved August 2, 2018 from: https://www.wijlimburg. nl/nieuws-overzicht/oproep-koninklijkemetaalunie-mkb-innoveert-te-traag/

Wiklund, J., \& Shepherd, D. (2005). Entrepreneurial orientation and small business performance: a configurational approach. Journal of Business Venturing, 20(1), 71-91.

Wilden, R., Devinney, T. M., \& Dowling, G. R. (2016). The architecture of dynamic capability research identifying the building blocks of a configurational approach. The Academy of Management Annals, 10(1), 997-1076.

Wilden, R., Gudergan, S. P., Nielsen, B. B., \& Lings, I. (2013). Dynamic capabilities and performance: strategy, structure and environment. Long Range Planning, 46(1-2), 72-96.

Wilkinson, A. (1998). Empowerment: theory and practice. Personnel Review, 27(1), 40-56.

Williams, L. J., Edwards, J. R., \& Vandenberg, R. J. (2003). Recent advances in causal modeling methods for organizational and management research. Journal of Management, 29(6), 903-936. 
Winter, S. G. (2013). Habit, deliberation, and action: Strengthening the microfoundations of routines and capabilities. Academy of Management Perspectives, 27(2), 120-137.

Wilson, A., Zeithaml, V. A., Bitner, M. J., \& Gremler, D. D. (2016). Services marketing: Integrating customer focus across the firm (No. 3nd Eu). McGraw Hill, London.

Yin, R. (2009). Case study research: Design and methods (applied social research methods). London and Singapore: Sage.

Zahra, S. A., \& Garvis, D. M. (2000). International corporate entrepreneurship and firm performance: The moderating effect of international environmental hostility. Journal of Business Venturing, 15(5-6), 469-492.

Zahra, S. A., \& George, G. (2002). Absorptive capacity: A review, reconceptualization, and extension. Academy of Management Review, 27(2), 185-203.
Zatzick, C. D., \& Iverson, R. D. (2011). Putting employee involvement in context: a crosslevel model examining job satisfaction and absenteeism in high-involvement work systems. The International Journal of Human Resource Management, 22(17), 3462-3476.

Zeithaml, V. A., Parasuraman, A., \& Berry, L. L. (1985). Problems and strategies in services marketing. Journal of Marketing, 49(2), 33-46.

Zhang, M., Macpherson, A., \& Jones, O. (2006). Conceptualizing the learning process in SMEs: improving innovation through external orientation. International Small Business Journal, 24(3), 299-323.

Zhang, W., \& Banerji, S. (2017). Challenges of servitization: A systematic literature review. Industrial Marketing Management, 65, 217-227.

Zhou, K. Z., \& Wu, F. (2010). Technological capability, strategic flexibility, and product innovation. Strategic Management Journal, 31(5), 547-561. 

Appendix: Interview guide 



\section{General questions}

- Introduction (Research goals, emphasize anonimity)

" Explore customer requirements from provider and customer perspective

" Theoretical, but also practical relevance of research for SMEs

- What is your role/position and responsibility? What is your age?

- Age organization \& amount of FTE

- What are your organization's global activities, existing product and service offering?

"What customer need does it fill?

- Why are you participating in this research?

\section{Servitization questions}

- Ask about and explain servitization

- To what degree is servitization relevant within your organization?

"If so, why did you servitize?

- How do you take customer needs into account when developing new services?

"What type of customers do you serve? B2B? National/international?

" Have you heard of co-creation? How have your customers been involved in developing new services?

\section{Specific servitized offering questions}

- What does the offering exactly look like?

- What information and insights about your customer's needs regarding this offering do you currently have?

- What do customers need when considering this offering? How can you convince customers of this offering? What are must-haves?

- What distinguishes your offering from competitors? Why will customers choose yoúr offering? 


\section{General questions}

- Introduction (Research goals, emphasize anonimity)

" Explore customer requirements from provider and customer perspective

" Theoretical, but also practical relevance of research for SMEs

- What is your role/position and responsibility? What is your age?

- Age organization \& amount of FTE

- What are your organization's global activities, existing product and service offering?

"What customer need does it fill?

- Why are you participating in this research?

\section{Servitization questions}

- Ask about and explain servitization

- To what degree is servitization relevant within your organization?

"If so, why did you servitize?

- To what degree are your suppliers servitizing? Why do they do this?

- Have you heard of co-creation? Have providers/suppliers included you when they were developing new services?

- Are you currently receiving services?

\section{Specific servitized offering questions}

... (SME name) can provide you the following offering: (explain the specific offering):

- What is the first thing coming to mind when hearing about this offering?

- What are important aspects of this offering?

- What are must-haves of this offering?

- What are the advantages and disadvantages of this offering?

- If you would need to choose between this offering and another provider offering more or less the same, what do you take into account when deciding? 


Valorization addendum 



\section{Knowledge valorization}

Universities are powerhouses of research, but policy makers and practitioners often refrain from using academic research to its fullest potential (Nutley, Walter and Davies, 2003). This can be partially attributed to differences in communication style: Researchers typically communicate in complicated, scientific language, whereas policy makers and practitioners need to make accessible decisions in a way that can be understood by everyone (Frenk, 1992). In order to make academic research more accessible, Article 22 has been added to the regulation governing the attainment of doctoral degrees at Maastricht University (2018). It specifies that a doctoral candidate shall include an addendum about valorization to their dissertation. This knowledge valorization refers to "the process of creating value from knowledge, by making knowledge suitable and/or available for social (and/or economic) use and by making knowledge suitable for translation into competitive products, services, processes and new commercial activities". In this research project, knowledge valorization was encapsulated in the composition of the research assignment and the project team - consisting of not only researchers, but also a policy maker from the province of Limburg and business developers from LIOF - and the close collaboration with SMEs in the province of Limburg. In this chapter, I further detail how this valorization has taken place.

\section{Knowledge valorization process}

The main practical objective attached to this research project was to examine to what extent the LimburgMakers subsidy program has structurally enhanced the competitiveness of participating SMEs. Over the course of the project, yearly reports informed all stakeholders about the research results and quarterly meetings took place between policy makers from the Province of Limburg, business developers from LIOF and the research team to exchange important aspects of the research. These included potential research avenues, content and dissemination of the questionnaires, and evaluation and communication of the results. The constant interplay between academics and practitioners benefited the research project in multiple areas: First, it ensured that the research results were relevant for industry stakeholders such as policy makers or SMEs. Identified theoretical research gaps were always cross-checked for their practical relevance. Second, the policy maker and business developers' networks were leveraged to increase response rates for questionnaires or to find participants for the qualitative study. Third, possible explanations and theories for the results were tested for their viability by making use of the policy maker and business developers' expertise and experience. Fourth, it enabled the wide dissemination of results: Through the policy maker and business developers' network the findings of the research were presented at multiple SME network events and to important stakeholders in the field of SME innovation. 


\section{Knowledge valorization content}

Chapter 2 guides policy makers in their search for robust evidence that innovation subsidy programs result in significant and tangible outcomes. As prior research has shown, innovation subsidies are associated with higher short-term SME R\&D input and output, such as patents and external collaboration behaviour (Clarysse et al., 2009). This study shows that innovation subsidies structurally affect internal collaboration behaviour as well. Namely, the findings reveal that receiving innovation subsidies has an effect on the involvement of an SME's employees. Employee involvement is known to be a driving force behind employee satisfaction, innovation performance, firm profitability and organizational effectiveness (Andries and Czarnitzki, 2014; Mendes, 2012; Porter, 1979; Pun and Chin, 1999). These findings provide policy makers with an important new rationale to employ subsidy programs as a tool to stimulate innovation within SMEs, thereby supporting the investments of the province of Limburg in the innovation project subsidies of the LimburgMakers program and potential future programs.

Additionally, this chapter reports a positive effect of employee involvement on SME product innovation performance. In light of this result, managers can boost their innovation performance by ensuring the involvement of their employees. Prior research suggests that showing their commitment toward involvement and offering rewards for employees that display the desired behavior are the most effective ways for SME managers to stimulate employee involvement (Pun et al., 2001).

Chapter 3 provides manufacturing SMEs with a roadmap to how they can achieve a competitive advantage based on service innovations. Price pressure and decreasing product margins, caused by intensifying competition (Gebauer et al., 2005), force SMEs to combine their products with excellent services to distinguish their offerings. The results of this study indicate that collaboration between internal stakeholders and with a diverse set of external partners, such as suppliers, customers and competitors, strengthen an SME's absorptive capacity - the ability to gather and use relevant external knowledge. In turn, absorptive capacity allows the SME to achieve a competitive advantage based on service innovation and evade price pressures and decreasing margins. Therefore, policies aimed at stimulating an SME's internal and external collaboration represent an effective method to strengthen the manufacturing industry. For instance, policy makers can organize network events during which SMEs are incentivized to cooperate with customers, suppliers, competitors, universities or local government. Next to this, a companywide workshop during which employees collectively work on an innovation case can intensify the involvement of employees in innovation efforts. In the province of Limburg, the central player and venue for such initiatives could be the Brightlands Campusses, where business, research and government are intertwined through a triple helix collaboration in the world's leading locations for smart services, sustainable manufacturing, healthy food and innovative diagnostics. 
Chapter 4 informs SMEs about the requirements their customers have for servitized offerings. It delivers a taxonomy of requirements for various servitization strategies. Taking the guidelines of this taxonomy into account is important, because not living up to customer requirements is one of the main determinants of failed servitization efforts (Valtakosi, 2017). SMEs can figure out how their offerings should be shaped to meet these requirements by engaging in co-creation with their customers. For instance, responsiveness could mean service within a few hours for one customer, and service within two days for another. However, this manuscript shows that only half of the SMEs in the sample engage in co-creation, despite its widely acclaimed critical role in achieving servitization success (Baines et al., 2009; Green et al., 2017; Tuli et al., 2007). Policy makers need to stimulate SMEs in this province to co-create. The Smart Services Campus is an ideal outlet to facilitate such initiatives, because co-creation is one of the pillars on which this Campus is built.

During the data collection process, two or three customer interviews took place for every SME that participated in this study. Next to the results that were aggregated and reported in chapter 4, important SME-specific insights were generated during the interviews. These insights were made available to every participating SMEs by means of a tailor-made report. An example of these insights was a customer of a software development SME mentioning that the software was too complex in its usage:

\footnotetext{
The software is installed at many farms, but many farmers tell me they stop using it after a couple of months, because it is just too complex. The program should be much easier to use, much more customer friendly. I should not need to read an instruction manual, I need to fully understand how to use it after 30 minutes of trial and error! (Customer of software development SME)
}

Without this PhD-study, this feedback may never have reached the software development SME, because it typically does not co-create its offerings with customers. Therefore, these specific insights further assist the 9 participating SMEs from the province of Limburg to servitize successfully.

To conclude, I would like to characterise this dissertation to a child raised by three parents: UM School of Business and Economics, province of Limburg and LIOF. Of course, the parents have had different roles - one provided daily care for the child while the others tended to their jobs - but each parent enriched the child's upbringing with his or her own, unique life lessons and experiences, granting the infant the strongest possible foundation for the rest of its life. I hope that after reading this dissertation you acknowledge the great value that resides in this type of research collaboration. 

Summary 

SME innovation is highly important, as it is not only a key antecedent of SME performance and competitiveness, but also spurs employment and growth of an industry. Unfortunately, SMEs often fail to realize successful innovation outcomes. In this dissertation, I investigate the drivers of SME innovation performance in three empirical chapters, turning to a different perspective on SME innovation in each chapter.

In Chapter 2, my co-authors and I adopt a policy maker perspective on achieving SME innovation performance by investigating whether innovation subsidies have an enduring effect on the innovation process of SMEs. Specifically, we examine the influence of subsidies that provide support for innovation projects on employee involvement by comparing subsidized to unsubsidized SMEs. We test this relationship by applying a conditional difference-in-differences analysis to our longitudinal data set, involving manufacturing SMEs in the Dutch province of Limburg. Our findings reveal a greater increase in employee involvement among SMEs that receive a subsidy, thereby providing compelling evidence for the structural impact of innovation subsidies on an SMEs' internal organization. In an additional analysis, we establish the important role of employee involvement in achieving product innovation performance.

In Chapter 3, my co-authors and I embrace an intra-organizational perspective to discover how manufacturing SMEs can achieve innovation performance. We draw on dynamic capabilities theory to explain how absorptive capacity - the ability to recognize, assimilate and utilize valuable external knowledge - is a critical factor in accomplishing service innovation performance. Our structural equation modelling analysis confirms this, and indicates that absorptive capacity is driven by the degree to which employees are involved in the service innovation process and the SME's diversity of external innovation partners.

In Chapter 4, my co-authors and I take a dyadic perspective, representing both SMEs and customers. We analyse both the requirements that customers establish for innovative offerings and the extent to which SMEs engage in co-creation when determining these requirements. With in-depth interviews across 24 SME-customer dyads, we conclude that about half of the SMEs in our sample engage in co-creation in the process of defining their customers' requirements for servitized offerings. Furthermore, we identify 9 customer requirements for servitized offering and find that their importance to customers depends on the servitization strategy the providing SME pursues. 

Curriculum vitae 

Kars Martijn Anne Gerard Mennens was born in Puth, The Netherlands on the 29th of May 1992. He completed his primary education in Bingelrade, and later obtained his high school diploma from the Gymnasium at Trevianum Scholengroep in Sittard in 2010. Thereafter, he started his Bachelor degree International Business with a major in Organization at Maastricht University School of Business and Economics. He spent his sixth and final semester at Nova Universidade de Lisboa in Portugal. After receiving his BSc. degree in 2013, he did an internship at a local consultancy firm - Tulser - to discover his deeper interests. As a result, he applied for the MSc International Business Organization, Change and Consultancy program in 2014, from which he graduated with distinction (cum laude) in 2015.

Feeling that there was more to his academic career, Kars started as a doctoral candidate in September 2015. The research project, connected to the LimburgMakers innovation subsidy program, had started in the beginning of 2014 and needed a new driving force. Being installed at the Departments of both Organization and Strategy, and Marketing and Supply Chain Management, Kars received guidance throughout his PhD-process from Prof. Dr. Gaby Odekerken-Schröder, Prof. Dr. Wilko Letterie and Dr. Anita Van Gils. His research focuses on innovation in SMEs and the effectiveness of innovation subsidies. He regularly presented his research to industrial (LIOF and SMEs) and governmental (Province of Limburg) stakeholders, providing him with invaluable feedback and insights concerning the practical relevance of his work. His first research project, on how to achieve a competitive advantage based on service innovation, was presented at the ICSB conference in New York in 2016 and published in the International Small Business Journal in 2018.

As of September 2018, Kars has been a Discover trainee at the B2B Department of VodafoneZiggo. 
